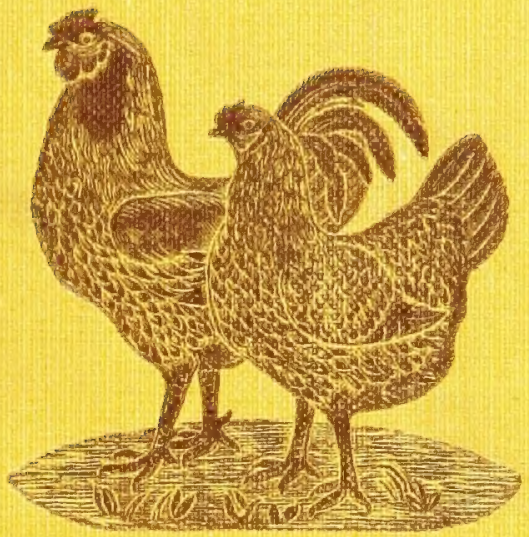




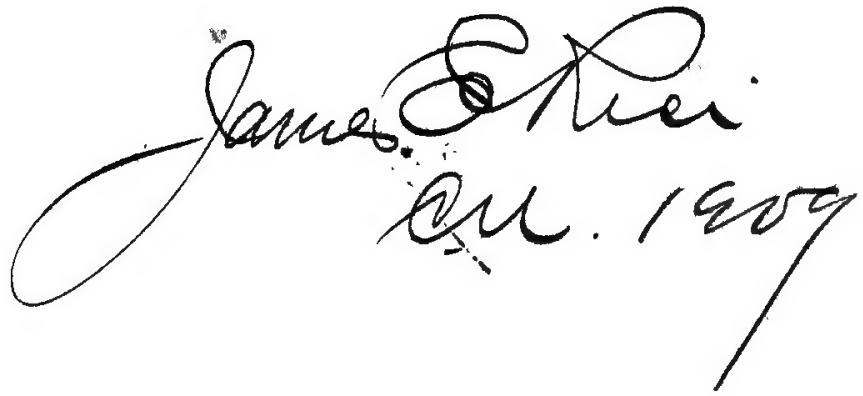

ALBERT R. MANN LIBRARY CORNELL UNIVERSITY

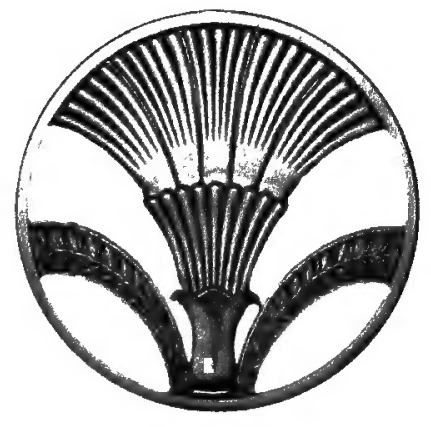

The Gift of

DEPARTMENT OF MiCROBIOLOGY AND IMMUNOLOGY 
lamberu.

$5 / N$ 


\section{Cornell University Library}

The original of this book is in the Cornell University Library.

There are no known copyright restrictions in the United States on the use of the text.

http://www.archive.org/details/cu31924089554731 


\title{
COMMON SENSE
}

IN

\section{THE POULTRY YARD.}

\section{A STORY OF FAILURES AND SUGCESSES.}

\section{HENS AND WHAT THEY DID.}

\author{
WITH A COMPLETE DESCRIPTION OF
}

The Houses, Coops, Fences, Runs, Methods of Feeding, Breeding, Marketing, etc., etc. And Many New Wrinkles and Economical Dodges.

BY

$$
\text { J. P. HAIG. }
$$

WITH NUMEROUS ILLUSTRATIONS.

NEW YORK:

THE INDUSTRIAL PUBLICATION COMPANY. 1907: 


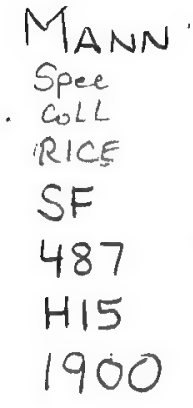

Entored According to Act of Congress, in the Year 188b, BY JOHN PHIN,

In the Offlce of the Librarian of Congress, at Washington, D C. 


\section{CONTENTS.}

Puplisher's Introduction,

Preface,

How it Came About,

Old Experiences and New Plans, - $\quad-\quad-\quad-\quad 27$

Trying to Improve the Old Stock, - - $\quad$ - $\quad$ - $\quad 38$

Facts and Fancies, - $\quad$ - $\quad$ - $\quad$ - $\quad$ - $\quad$ - 47

Working Out a System. $\quad$ - $\quad$ - $\quad$ - $\quad-\quad-\quad 53$

House Building, - - $\quad$ - $\quad$ - $\quad 59$

Broods Increase and Troubles Begin, - $\quad$ - $\quad$ - 73

Preparing for a Start, - - . $\quad$ - $\quad$ - $\quad$ - 84

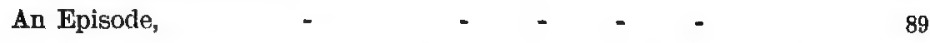

Yards and Fences, $\quad$ - $\quad$ - $\quad$ - $\quad 94$

Breeding Pens, $\quad$ - $\quad$ - $\quad$ - 103

$\begin{array}{llll}\text { Making a Start, - } \quad \text { - } & 107\end{array}$

Undei Way at Lastan More Help Needed, - - - - - 116

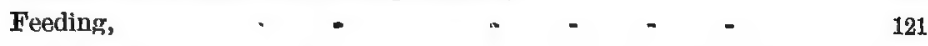

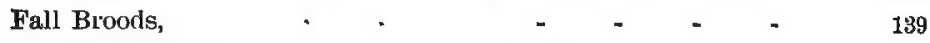

Our First Winter, - $\quad$ - $\quad$ - $\quad$ - 14

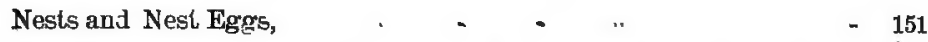

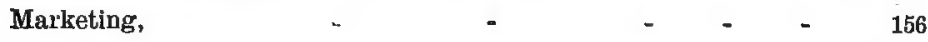

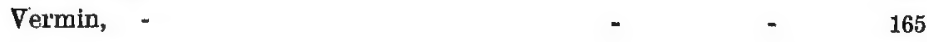

Enemies, $\quad-\quad 168$

Early Chickens and High-Pricea Eggs, . 175

Retrospective-Profit and Loss, - - - - - $\quad 182$

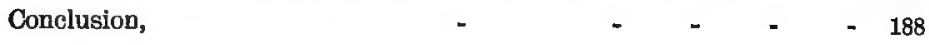





\section{PREFACE.}

TRIFLING as chickens and eggs may, at first sight, appear, it is, nevertheless, a fact, that the output from the poultry of the United States exceeds in value that of all the silver mines therein. Therefore, whatever will add even a trifling percentage to the proflt derived from our poultry must be, not only of individual, but of national importance, and it is by the hope that he might accomplish something in this direction, that the author was induced to prepare the present work.

I have put the subject in the form of a story, in the hope that some who would be repelled by a mere treatise may find the work sufficiently interesting to read it through. But although the principles and methods are strung on a slender thread of fiction, they are none the less true. Every house described, every device herein detailed, every method practiced, has been successfully used as related, so that the reader need not hesitate to put up coops and use them after these patterns. I have given the best practical results of year's of experience, and not the mere imaginings of a theorist or a novelist.

In some of the chapters, notably that on feeding, I have been obliged to abandon the story for'm, and to give my results in a general form, otherwise, this chapter would have expanded into a book. And in other chapters, for the purpose of giving the practical information more thoroughly, I have frequently anticipated the course of events as they actually occurred.

I firmly believe that the methods herein detailed are the very best for all those who do not aspire to the refinements of the business-incubators, etc. While these are no doubt valuable aids to the extensive and experienced poulterer, I am afraid they are not the thing for the ordinary chicken raiser. I must confess that I have never owned an incubator, but I have entrusted eggs to men who claim to be professionals in their use, and I have not been so encouraged as to be induced to try it again, unless some new and more powerful inducements are offered. I have always been able to command enough brooding hens to meet my wants, and my success with them has been far greater than anything that has come under my observation from the incubator. But of course this is only my own experience, and under different circumstances that experience might have been very different; so that I hold that in this matter each man must decide for himself.

In the earnest hope that my readers will derive as much pleasure and profit from their poultry as I have done, I place this little book in their hands.

Ferniebrield, May 1st, 1885.

J. P. HAIG. 



\section{PUBLISHER'S INTRODUCTION.}

IT is an old saying, and one very generally accepted, "figures cannot lie." If by this is meant that two added to two always make four, it camnot be clenied. But, two and two do not always make four. Sometimes they make twenty-two, sometimes they make ;, and sometimes they make $o$, so we see that it is not the figures alone, but their position as well, that governs the general result. When Captain Bobadıl proposed to exterminate an opposing army by kulling them off at the rate of ten every half hour; twenty an hour-ten hours a day, two hunclred men-a hundred day's, twenty thousand men-the figures clid not lie though the Captain did. The growth of numbers under the potent spells of the arithmetician is something marvellous. No matter how small the profit, if the number of articles on which that profit accrues is only great enough, a fortune of any desired amount may be achieved. No better illustration of this occurs than that of book publishing. If the ordinary profit on a book is 25 cents, we have only to sell ten times the number at a profit of 5 cents, to obtain twice the income; and as low prices bring increased sales, here is a road to fortune. And so strongly did this idea take possession of one publisher in this country, that he attempted to sell books at a profit of only I cent apiece, in the hope that by selling millions, the aggregate profits would be larger than by the usual plan. Unfortunately for. his scheme, a profit of one cent is not difficult to wipe out. It does not take many spoiled copies; not many minutes wasted by clerks; not very much postage, to throw the balance the other way. At any rate the man who triel it soon found himself a bankrupt.

Perhaps in no case is the power of multiplication and the 
consequent certainty of a fortume more strongly presented than in the poultry business. In the first place the number of chickens which can be raised from one healthy hen in a few years is something astounding. " Let us begin with one healthy young hen; let us stuppose that slue and her female progeny will live for seven years, (which is greatly within bounds) and rear two broods of I 3 each, every season. Let us also suppose that half her chickens are cockerels, almost all of which will be killed, except those required for breeding, and therefore let us make no accouut of them. 'l'hen it will be found that

At the end of the first year we have the original hen

and $\mathrm{r}_{3}$ chickens, making At the end of the second year we have

\begin{tabular}{|c|c|c|c|c|c|}
\hline " & “ & third & " & ¿ & 2,744 \\
\hline “ & " & fourth & " & 6 & $3^{8,416}$ \\
\hline a & " & fifth & " & “ & 537,824 \\
\hline & “ & sixth & “ & “ & $7,5^{29}, 53^{6}$ \\
\hline & " & seventl & "6 & " & - $\quad 105,4 \times 3,504$ \\
\hline
\end{tabular}

Here then is a chance for a fortune. I et us emigrate to some western prairie, where we can find unoccupied land which we can use for a few years-just as do the great cattle robbers-we beg. their pardon, we mean Cattle Kings-and let us take with us a single hen. At the end of seven years we will be the happy possessors of one hundred and five millions of chickens, which at the very low price of ten cents eacls, would make us worth over ten millions of dollars. At the end of that time, therefore, we cain sell cut, come east and enjoy ourselves.

Of course, in such an extravagant statement as this, the fallacy becomes too obvious to allow of its deceiving any one, although in this, as in other cises, the figures do not lie. But, when men come to talk of thousands the impossibilities seem to disappear and it does not seem that propositions which are backed by such clear calculations, and are sustained by apparently well known facts, can be anything but feasible. Thus, some man reports that, from his flock of thirty hens he has made an annual profit of thirty dollars; and 
the question at once arises: Why cannot $\$ 3,000$ be made from 3,000 hens? In the first place, it is rare to find in such calculations that anything is set down for labor, the care of thirty fowls being regardecl as mere pastime and occupying, we will say, only three-quarters of an hour per day. But, let suppose that our flocks increase to 600 bircls-a comparatively small number. We now find that insteal of three-quarters of an hour per clay we have to give fifteen hours per day-a demand upon time and strength which would soon break down any ordinary man.

Somebody, claiming to have 3,000 fowls, tells us that we ought never to let a day pass witliout examining personally each bird, so as to see if it is in health, and he further declares that only in this way can we be sure of success. Let us see. Suppose it takes just half a minute to examine a fowl carefully; then, to examine 3 ,000 fowls will take just $\mathbf{I}, 500$ minutes, or 25 hours, which is a little more time than we have ever been able to put into a day's work. The fact is, that very few people have any idea of what a thousand is, and none have any idea of what a million is. One man wrote a book of recipes, etc., and has advertised it as " $A$ Million of Facts for the People." His book consists of about 1,000 pages; there are 53 lines to the page, and about Io words to a line, or 530,000 words in the book, so that if his claim be well founded, every word must embody the statement of at least two facts!! It is needless to say that the claim has no foundation in fact.

The same unsound calculations which seem to infest poultry keeping are found to affect almost every other business, and success is only to be attainerl in any unclertaking, by intelligence industry, economy and perserverance. As soon as we get beyond a very narrow limit, the influence of personal zwork becomes a trifling element, and we have to depend upon the help of human beings quite as much as upon the good qualities of our fowls. And every one knows how uncertain and unreliable most human help is.

We do not make these statements for the purpose of deterring any one from entering upon the raising of poultry on a large scale, provided they bring to the undertaking the requisite amount of 
experience, skill and capital. But, without these, failure is almost certain, and we should be sorry to aicl in distributing a work which would lead enthusiastic but inexperienced persons to lose what little capital they may have. As for the keeping of poultry on a small scale, that is always to be commended. Poultry are the scavengers and save-alls of the nation. The aggregate savings of the little flocks of ten to a hundred fowls that are scattered throughout the country amounts to a greater sum than the value of the cattle and horses pit together, and to more than the output of our much lauded silk industry, with all its huge mills, imposing warehouses, and aristocratic mill owners. And yet, with all this, six hundred and sixteen thousand dozen eggs passed through the Custom House in New York during the months of October and November of last year-showing plainly that the market for eggs is far from being glutted. Poultry when kept in small numbers on any place can, in general find a considerable share of their food in scraps that would otherwise go to waste, and in insects, seeds, etc. They are therefore alway's profitable, and as pleasant as they are profitable. It is only when this and similar rural pursuits are taken up as a buciness that any danger of failure exists, and in such cases failure generally arises from the fact that those who embark in the undertaking make the great mistake of supposing that because they lave a love for birds therefore they must have the ability to care for them. 


\section{COMMON SENSE}

\section{IN THE POULTRY YARD.}

fiow it Utame A bont.

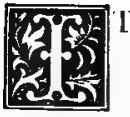

I' has been said that every man thinks himself competent to edit a newspaper. With much more truth might it be said that every man thinks homself competent to invest money to advantage. And it is hardly necessary to say that in both cases a large proportion of the men who think thus are mistaken. Thousands of men have found, lyy sad experience, that one of the most difficult thming to do is to invest money to advantage and yet securely. I never supposed that I was specially gifted in this way, but having occasion to invest the savings of many yearsa small sum after all, by the way- $I$ supposed that as good a plan as any would be to follow in the footsteps of those who might be regarded as experts at the business. I do not now speak of speculation or investment in enterprises which promise large results, with, of course, a corresponding risk, but of those investments which are supposed to be permanent and secure, and upon which a min may rely for a certain income for limselt, or for his family if he should be taken away.

The prosperity of the country was at high tide at the time of which I write. Every species of investment promised seçurity and a liberal income, and the values of real estate were constantly increasing. Nor did this increase seem to be a speculative one. The people were growing richer, and could afford to pay more for 
home accommodation; the number of those who wanted dwellings seemed to be constantly increasing, and consequently there seemed to be absolutely no reason why prices should ever fall. Not only were private individuals lending liberally on bond and mortgage secured by real estate, but those professional experts who are retained by vast monied corporations-insurance companies, savings banks and the like-were investing the capital of their principals in these securities, City property always commanded liberal loans, and farms in good concition were considered very desirable security. And on what is known as suburban real estate loans to a large proportion of their value could be obtained. When, therefore, my friend Brown applied to me for a loan on his new house and grounds, I had no hesitation in entertaining his proposal. He had paid $\$ \mathrm{I}, 500$ for eleven acres of land, and hat spent $\$ 8,000$ more in luilding a substantial and comfortable house upon it, and in improving the grounds. When, therefore, he applied to me for a loan of $\$ 3,5^{\circ 0}$, I regarded it as a very fortunate occurrence for me, and after the necessary formalities and searches had been made, I gave him my check, took the bond and mortgage, and had the latter recorded.

Brown was a Scotchman of more than usual intelligence and energy; he was in a good business, and as his family was growing up he decided to own a place in the country. He had bought a somewhat wild piece of land near a large country town, but his taste, knowledge and skill had transformed it into a marvel of heauty, and a source of many comforts. It was situated on a hillsicle, commanding an extensive and beautiful view, and on the northern boundary the land rose in a rather steep and rocky slope, the face of which was covered with ferns, while along the top was a. strip of evergreens which afforded a perfect shelter from the northern blasts. 'This rocky and ferny shelter had struck Brown's eye from the first, and decilled him in choosing, or perhaps I should rather say in making, a name for his place. $\mathrm{He}$ called it Ferniebield, which he told me signified in Scotch ferny shelter, and well did it describe the locality. The name always seemed to me quite a poetical one as well as an uncommon one, and many a pleasant hour did I spend there enjoying the romantic walks and splendid 
views, but, above all, the intellectual converse of my friend Brown, who was not only a highly educated man, but a man of great natural ability.

For a time all went well. Business was good, the interest was paid promptly, and Brown even thought of reducing the mortgage. But, alas, for human hopes and plans. One of those commercial cyclones which seem periodically to shake the very foundations of society, overtook us; business became as dull as before it had been prosperous, and Brown with the rest found his income reduced beyond anything which he had deemed possible. Economy was tried on every point, and his family aided him in every way to cut down expenses and make both ends meet, but witlrout success. There is a pount heyond which economy cannot be carried, if we would continue business at all, and Brown's business expenses were actually greater than his income. As a necessary consequence he defaulted on his interest, and matters daily grew worse. He then tried to sell, hat found it impossible to get even the amount of the mortgage, for teal estate had probably suffered a greater reduction than any other species of property. The speculation in real estate had run high; the opinion had been universal that real estate possessed a solid and almost unchangeable value; that if it went down a little now and then, owing to local causes, it would sonn rise again; and that at any rate it conld never go very much below the prices at which it was held. When, therefore, those who had held these opinions saw it go down, down, and never rise; saw it go far below what they had always regarded as the lowest possible limit, they became panic stricken, and would no more have bought real estate as an investment than they would have bought Keely motor stock. Aucl as for selling stiburban residences, that was out of the question. All who could afford to buy and to live in such places were supplied, and many who had made such investments were forced to give them up, since their diminished incomes no longer enabled them to support the expenses that were absolutely necessary. The market was easily glutted, and buyers with cash were able to obtain the most beautiful and comfortable homes almost at their own priess, 
Things looked discouraging indeed, and for two long years Brown struggled on, hoping against hope and looking for a change. But the change did not come; or at least it came so slowly that the "hope deferred máde the heart sick." Meantime the interest accumulated, and the want of it cramped me, for my regular income was also diminished. I had no thought of foreclosiug, and yet. it would never clo to let the matter run on until the property would be lost to us both. I did not hint this to Brown, but be saw it as clearly as I did, and at last approached me on the sulject. The result of our conversation was that we both resolved to make a determined effort to sell it, even if it brought no more than the amount of the mortgage and interest. But after six months hard effort we found that we could not get a buyer even at this low price. Thoroughly discouraged, Brown suggested that I take the place myself. He had an offer from a western frm to take the management of a department of their business at a salary which, even if moderate, would at least enable him to live, and lye suggested very sensibly that to close out by resorting to law would only involve expense without any real benefit. He had an opportunity to close out his business in the city for a sum which would enable him to get settled comforțably in his new home, and he had decided to take this course provided he could arrange with me.

'I'o fight against the inevitable is folly: Even if I had refused to accept his offer, and had held on to my mortgage and foreclosed it by legal measures, I would have gained nothing but a loss, as the Irishman said. It seemed hard to take property that had cost over $\$ 10,000$ in exchange for a mortgage of little over one-third that amount, but both Brown and myself saw that it was not our doing so much as it was in obedience to the "inexorable logic of events." So far as I was concerned, all I wanted was the amount I had put into the investment. Brown had taken chances; I had taken none. If the property had increased in value to double its cost Brown only would have been the gainer, and so as I had no share in the possible profits it was only just that I should have no part or lot in the losses.

And so, in order to avoid all litigation and expense, Brown made. 
out to me a deed of the property, and agreed to give me possession as soon as the necessary arrangements could be made. I must confess that I felt no pleasure in my new property. Although it was certain that I would gain by it in a few years, yet when I saw the deep sorrow which settled over the family when they found themselves obliged to give up their beautiful home, any satisfaction which I might otherwise have felt was destroyed.' In order to relieve Mrs. Brown's mind as far as I could, and infuse a hope which might cousole even if upheld by a very slender prop, I agreed to restore the place to them at any time within three years on payment of the original mortgnge and interest to the date of $\mathrm{my}$ taking possession, the rent after that time being considered a full offset for the interest.

It is unnecessary to enter into further details of the change. I have given these facts in order to explain why it was that I came to select such an expensive place for a poultry experiment: I did not select it; it selected me, and though now, after some years, neither Brown nor myself have much cause to regret the change, yet at the time it was a pretty severe trial. As I have already told ny readers, Brown was a man of great ability, and in his new position he rapidly made himself invaluable to his employers. Rival firms were not slow to see that the great success of the new management was due entirely to Brown, and so persistent were their efforts to secure his serrices that the firm he was with admitted him to a partnership, and he is now a very wealthy man. He occasionally visits us and enjoys his old home. The best of feeling exists between us, as may be readily supposed, and although he was well able to buy back the place before the limit of time had expired, he did not consider it wise to do so. He could not return to it and live in it without making an altogether disproportionate sacrifice; to rent it would be to allow it go to the dogs, and as for selling it, that was yet out of the question. There is therefore no danger that my possession will ever be disturbed.

There were quite a number of useful animals and articles on the place which were now of no use to the original owner. In order to get at a valuation of these we made out a complete inventory, 
and employed an experienced auctioneer's clerk who affixed to each article the price which he thought it would bring at auction. 'The aggregate sum was beyond that which I cared to invest, and I suggested that the goods had better be actually sold at anction. Mrs. Brown strenuously objected to this, however, and with her woman's sense suggested that if we would dispose at private sale of some of the articles that I did not want, and deduct from the valuation of the remainder the expense of selling, the amount might probably come within my limit. Taking off auctioneer's fees, advertising, time, etc., reduced the latter sum very materially, and I bought the goods at their reduced estimate. Amongst the new acquisitions were a fine old mare (Madge she was called), an excel- . lent cow-almost pure Jersey, though not registered-a covered buggy, spring wagou, dirt cart, harness, and the usual supply of agricultural tools. There were also over fifty hens and some pigeons, but the latter were not inventoried. At one time "Brown had some very fine poultry, but during his troubles the flock ran down until now there was nothing but some fifty or sixty old hens of a rather mixed breed, and a solitary cock. At this time, lowever, I did not care much about the kind of poultry, and although I was familiar with the different breeds and knew a good bird when I saw it, yet I luad no intention of doing more than merely securing eggs enough for family use.

All this occurred in early spring, and, of course, it was necessary that I should take possession as soon as possible, so that the ground might be put in ordep for spring crops. But meanwhile it was found advisable for Brown to visit his new home, not only to make arrangements for moving and establishing himself there, but also to consult personally with his employers. All this was going to take time, so I suggested that they give us possession at once and remain as our guests until they found it convenient to move. Under other circumstances this would have been anything but an agreeable arrangement, but under the present conditious it was thonght best to do so. So Mrs. Brown commenced packing and soon cleared rooms enough to give us an opportunity to move in. We secordingly gave up our house in the village-a tenant having 
been already found - and moved all our goods and chattels on to the place. Some were stored in the barn, others were put to inmediate use, and others were stored in vacant rooms. I was enabled to aid my friends materially in packing up; the work on the place went on smoothly, and ere long it was time for the Browns to depart for their distant home. Mr. Brown had returned and finished packing. Most of his goods had been sent to the railroad dejol and others stowed away in the barn until it suited his convenience to send for them. At last the day arrired when I was to drive them over to the depot, and that day I shall never forget. As may readily be imagined the children had become deeply attached to every animal and almost to every plint on the place. The horse, the cow, even the chickens, were all old friends, and the parting was painful to the last degree. But it ended at last, and we left Ferniebield in anything but a joyous mood. A short drive brought us to the neighboring station; the train rolled oit of the depot and I returned to my new home-sad, it is true, but with a very different feeling from that which I had bitherto entertained. I now felt that I was absolute master and owner of the place. So long as the original owner remained I could not get rid of a feeling that I was subordinate to him. But now I was not only sole possessor but sole occupier, and after unharnessing the mare and tying her in her stall, I walked over the grounds and examined them as I had never done before.

The weather had become settled and warm, and the plants were developing with spring-tide vigor and rapidity. 'The garden, which had been the pride of Mrs. Brown's heart, was as yet almost untouched by spade or hoe, for the pressure of other things had prevented attention to aught except the useful. A few early vegetables had been planted, but that was all; but the onc plants were springing up everywhere, as if looking for their lost mistress, and wondering where was the careful and tender hand that had always hitherto guided their wayward growtl. It was late in the season to begin gardening; the buds on the vines had swollen, but the rampant growth of the previous year still hung untouched upon the trellises. Other plants showed the same neglected condition, and I turned 
away with saldened steps and went towards the animals. The prigeons and hens had been the special pets of my little friend, Nettie, the fourteen year old daughter of $\mathrm{Mr}$. Brown, and she lind fed and petted them that morning amongst the very last things she did. 'I'hey now looked' upon me with a curious eye, as if to say "What are you dcing here?" 'llue horse and cow seemed to miss their former owners less, though I fincy that Madge has not yet quite forgotten her old friencls, and still looks about and wonders when they will return.

Returning to the house, I sat down under the veranda to think over the situation, for, I confess, I did not feel altogether satisfied, and sometimes I doubted the wisdom of my accepting Brown's offer. Still, if the worst came to the worst, I could sell it yet for whatever it would bring, and then I would be better off than if I had forced a sale by law and diverted a large portion of the proceeds into the pockets of lawyers and sheriffs.

After making a very close calculation, and as accurate an estimate as my knowledge of the facts in the case would permit, I came to the conclusion that our expenses in our new home would be from six to eight hindred dollars per year more than they had usually been. In making this estimate I charged taxes, insurance and interest as rent; repairs I clid not include, for I fully believed that the steady rise in the value of property would more than offset this item.

Our increased expenses were due to the fact that we would have to keep a man, a horse and a cow, and that the bouse being mucin larger than was really necessary for our family, would als $\emptyset$ entail extra expense in the way of fuel, help, etc. The place, too, would require to be kept up, so as to present at least a decent appearance, or it would soon become less valuable.

It is true that for all this we had our returns in the shape of increased advantages and pleasures, but this did not lessen the amount that had to be paid for them. I had fully allowed for the saving that might be effected by having a full supply of such articles as eggs, milk, butter and vegetables, and had even estimated certain receipts from orchard and garden as possible income; but, 
after all, I had found that our expenses would be greatly increased, and how were we to meet them without interfering with other obligations that were imperative? 'This was the question that presented itself to my mind in such a clear and definite shape.

'Iwo ways presented themselves: Either I must find some extra business which would yield the required amount, or the place itself must be macle to yield enough to pay the deficit.

'The first plan was out of the question. I had already withdrawn as much as possible from active business, and I had no idea of again saddling myself with its cares and anxieties. And to accept a subordinate position would now be exceedingly clistasteful to me. If I engaged in any pursuit to make this money the business must be very congenial, and it must leave me entirely independent, otherwise it would be wiser to sell the place at a sacrifice and live more cheaply.

It seemed, therefore, that there was no alternative but to make the place produce the required extra amount. Let me therefore describe it in detail.

The house was, as I have said, larger than was necessary for a small family in moderate circumstances. It contained twelve rooms, was heated throughout with hot air, had water-tanks, bath room, water-closets, etc., etc. In short, it was as complete in its appointments as most city houses. It is with the grounds, however, the productive part, that we have chiefly to do, and therefore I shall say no more about the house itself.

The land lay along a road which led from a large and thriving village into the country. The village almost aspired to be a city, and would luave been one long ago if the good sense of the majority of the inhabitants hat not restrained the ambitious vanity of a few. 'The road ran almost straight until it reached the foot of a somewhat precipitous hill, when it turned sharply to the west and went round the foot of the mountain. My land was bounded by this road on the west and hy the mountain on the north. The "mountain," as it was generally called, was a steep and bạ rren hill about 200 feet high, reckoning from the plain at its base. Just above the base there was a rocky cliff, and above that the line of 
evergreens to which I have alluded as giving the place a portion of its name. My line ran along the top of the cliff, but did not include much of the evergreens. 'The mountain itself seemed to belong to nobody. It was almost barren; cattle would find no pasture on it, and sheep could not be kept in that region on account of the village curs, which were constantly prowling about, and would soon have destroyed any sheep that might have been kept. It had been sold for taxes several times, but no biclder had ever taken possession and kept it. My line ran along this cliff for a few hundred feet, and then turned straight down the hillside. When half way between the cliff and the plain the line turned to the east, and ran in this direction for some distance, after which it descended to the line of the next property, and then ran in a wavy westerly direction till it met the road alreacly mentioned. If the reader will follow this description, marking the outlone on paper with a pencil, he will see that the property had almost the form of a boot, with the toe lying towards the morning sun. And, indeed, so strong was the resemblance to a boot, as seen on some plans and surveys that had been made, that it had actually been called "I'he Boot" before Brown bought it and gave it a more poetical name.

Such being the general "lay of the land," an account of its varying character will now be more easily understood. I say varying, for even on this small plot of ground varieties of heavy and light soil were found, as well as black vegetable mould. Under the cliffs the ground was mostly covered with rocky debris, which was entirely barren and irreclaimable. In spots the broken rocks were covered with sandy loam which had gradually washed out of the very thin soil above. On these spots, however, nothing grew, because they dried so very quickly, except where they were kept moist by perennial springs, several of which trickled down the cliff, their course being marked by the exuberant growth of ferns which sprang out of the rocks, growing in little pockets filled with rich black mould. A few yards from the base of the cliff the soil became richer and deeper, though still very stoney, and the further down, the better the land became. On this ground was formed the 
vegetable garden. By great labor and much care the rocks had been removed, and even the small stones picked out to a great extent. A plentiful supply of good stable manure had been added, and a very rich and fertile soil was the result.

Between the vegetable garden and the house was a strip of grass land, used generally for laundry purposes, the back of the house facing this way. At the front of the house was the carriage drive, which was carried round a large oval grass plot, at one time laid out as a croquet ground. Beyond the drive was the lawn proper, and along the edge of this were numerous flower beds, while beyond that stretched an unbroken field of green grass with a few ornamental trees scattered here and there. The house was distant about one hundred feet from the road, the approach being under two rows of soft maple trees, which now gave promise of soon forming a dense leafy arch overhead.

The lawn was bounled on the south and west by an irregular row of evergreens, which gave an air of seclusion to the grounds, the land south of the evergreens being either used as a pasture field or cultlvated, as circumstances might direct. This was the lowest part of the grounds and the richest.

Returning to the eastern boundary: At the point where the line, descending from the hill, turned towards the east, were placed the barns and stables, and between these and the lawn was the orcluard. 'The toe of the boot formed a nice little paddlock of about three acres, which had always been used as pasture for the horse, cow, calf, etc.

A little above the barns, and within a few yards of the eastern boundary, there gushed from the hillside a sparkling spring of as pure water as I ever belield. The water from this spring formed a good sizer stream, and flowed straight down through the grounds, passing direct!y into the land of our neighbor on the south. It furnished all the water necessary for cattle, and various other purposes-washing, sprinkling, etc., and was never-failing. By means of a hydraulic ram a supply was forced to a tank at the top of the house, so that the supply there was constant and abundant. For drinking purposes we used the water from a well, which was 
so deep and clear that ice was a wholly unnecessary luxury, even for the care of milk and butter.

As regards the area that was covered by the several divisions which I have described, it was about as follows: The house, garden, drive, barns and barnyard covered about two acres; the lawn about an acre and a half; the orchard about half an acre, and about two acres were occupied by shrubbery and barren ground. This left the paddock of three acres and about three acres more of good tillable land. The question now was, "What can I do with it?"

My first thoughts ran to the raising of "truck," as it is called, "and I studied several works which professed to give the detailed experience of men who had made money in this business. I concluded that I had about three available acres, the rest being required for the support of the horse, cow, etc. What crop should I raise? My object was not sn much to establish a higlly profitalble business as to clear a certal s rmount-say $\$$ r,oo per yearwith certainty, and without an immense amount of labor and care. On reading the books alluded to, I folmd that in the hands of skilful gardeners, in the neighborhood of our large cities, a single acre was quite sufficient to yield this amount as profit. Nevertheless, I doubted my own ability to succeed in such an atlempt. True, I had had some experience in gardening, but not as a business, and while I had no doubt about my succeeding in raising fair crops, yet whether I could do it and make it pay was another question. 'The raising of cabbages was carried on quite extensively in the neighborhood, and at a good profit, as the land seemed to suit them, and plenty of manure could be had by the car load; carrots, celery, cauliflower and on: or two others generally commanded good prices, and when not saleable in our market could be sent to the city, where the demand was always good. Asjparagus struck me most favorably, and I determined to put out at Ieast one acre of this plant at any rate. I knew by my own experience that asparagus always commanded a high price, and even if the general demand fell off, good bunches would always sell well. The city would always take all I could raise, and after the first work of start- 
ing the bed the labor required seemed to me to be less than that needed for any other crop. Moreover, my thoughts were turned in this direction because I had always believed that the land south of the lawn was particularly well adapted to asparagus. There was, in the vegetable garden, a small asparagus bed which had always yielded a fair crop, but nothing extra, and this harl given the impression that the land was not specially aclapted to its culture. But wandering one day about the grounds, duriag the previous season; I came across an asparagus stalk yrowing in a corner of the fence near the boundary line. I was astonished at its size and vigor. I dare not state the height to which it had attained, for few of my readers would believe me; they would certainly think that I had mistaken some other and unknown plant for asparagus. It brought me in mind of the scriptural description of the mustard plint, for verily I beheld the birds of the air lodging in its branches. So here I marked off my asparagus bed, and I have never had occasion to regret the selection.

One of the diffizulties with asparngus, however, is the length of time which is required to bring a bed into good begring condition. It was now too late to establisly a bed that season, and as I had to allow the plants at least three years to become estalslished, the prospect of returns seemed rather distant.

$U_{p}$ to this time I had never thought of poultry, and if any one had suggested these useful animals to me as a source of income I would have regarded the proposition with considerable disfavor. I hasl great faith in the profits that might be macle out of a small flock of hens, and I had even speculated on the possibility of keeping poultry on a large scale successfully, but in my previous calculations the poultry had been used rather as mere concentrators than as direct sources of profit. In other words, by converting corn, wheat clover, etc., into poultry and eggs, I believed that much freight might be saved, the fertility of the land not only maintained but increased, and thus a fair profit secured. And I believe all this to-day with even more steadfastness than I did then. But to make poultry a paying lwisiness on three or four acres, even with a few extra acres of orchard 
and shrubbery for them to range over, was foreign to the previous train of my thoughts. Of course there was one branch of the poultry business that might be macle to pay even on a single.acre; I refer to so-called fancy or pure-breal fowls, but this was a branch of the business for which I felt myself totally unfitted, and for which, owing to certain previous disagreeable associations, I had a most intense dislike.

I In previous years, wherever I had had a home with even a garden attached, I had always kept a few hens and always with success, and now as I have already stated, there were in our barnyard quite a flock-some fifty or sixty hens-left by Brown. We had even gone so far as to set a few hens, and already there were several small broods wandering about the orchard. For experience had taught me that young fowls whose flesh had been accunulated in the open air, with all the freedom of the hillsides, and the health which plenty of exercise and the ability to select natural food confers, were infinitely to be preferred to the birds usually brought to market, most of which had been confined in dirty coops for two or three weeks before being killed. It does not require one to be much of an epicure or a judge to tell the difference. I had, therefore, taken steps. to raise enough for our own table at least, and thus far we had had tolerable success, though not at all what I expected, from my previous experience. The young chickens did not seem very strong, and they certainly were of no particular breed, for the flock was rather a motley one. With the exception of a few old white Leghorn hens it would have been difficult to tell what they were. Amongst the rest, however, was a very pretty Seabright bantam hen-the especial pet of little Nettie; and here I cannot forbear to digress a little and give the reader her history. This bird was the last one of a trio that had been given to Nettie by a friend, and she made me promise that when she got settled in her new home I would pack up " Bright Eyes" and send the bird to her, either by express or by some one willing to take charge of her. As Nettie was a favorite of mine, and very fond of me, I was only too glad to make the promise. The other hen of the trio had, during the previous season, hatched out seven beautıful little chicks, 
and was rearing them successfully through all the perils of chickenhood, when one unfortunate day they strayed off their own grounds on to those of the neighbor on the south, and, as there was not the best of feeling between brown and the other man, the latter set his dog on them and killed the mother and all her brood. He then tossed the dead bodies over the fence. It was a brutal action-but no, I must not say that; it would be a libel on the brute. Brown might have shot the dog a dozen times, for the animal was frequently on his grounds without permission, but he was too much of a man to revenge himself on a dumb creature. Moreover, the dog was a very fine one, and a great favorite with others besides the wretched master whose instigations he had obeyed. Nettie was terribly shocked by the death of her pets, and the remaining birds became more than ever precious.

One day, not long after this, Brown found the dog on his grounds. He coaxed it to him and tied it up. He then wrote a note and sent it to the owner, asking him if he should shoot the dog, or if he would come and take it away. He did not reply; but his wife, a lady who had been very much chagrined at her husband's churlishness, and who had sent Nettie a beautıful mocking bird witl a note of deep regret and apology, came over and begged to be allowed to take the dog home. To such a woman few requests can be denied, but my, readers will not wonder that after all this we called our neighbor on the south $\mathrm{Nabal}$.

The little Seabright rooster met an untimely fate in a different way. Pugnacious beyond all expression, he would fight anything that wore feathers, no matter what its size, color or previous condition. One day, however, Brown bought some live chickens for table use, and amongst them happlened to be a thoroughbred game cock, a very hancisome and powerful bird. The little Bantam attacked him as soon as he was set free from his coop. At first the game cock would hardly notice him, but the Bantam persisting in his attacks, and probably hurting the other so as to rouse him up, was killed in less time than it has taken to tell of it. Brown saw at once that the conqueror woukl, e a val able aldition to his yard, and I suspect that this new and thinroughured blood did a great deal to 
produce the fine quality of half a dozen of the hens which $I$ found on the place, and which were marked exce!ntionis to the rest.

So the little Bantam hen was left alone by herself, and it occurred to me that I would give Nettie a surprise. The hen was laying, but of course her eggs were not fecundated. A friend of mine, at some distance, however, had, as I knew, some very fine Seabrights, so I drove over to his house, taking the little hen with me. I I explained what I wanted and what I wanted it for, and as a matter of course I left the hen behind. In a few weeks I received from my friend ten little eggs, which I set under a quiet old hen, and in due time had nine of the prettiest, smallest chicks I had ever seen. Nettie had already written for her hen, but I excused myself on one ground and another. Now, however, I had no excuse. The hen herself had been sitting on eggs for ten days, so I drove over and brought her home, nest and all. The same evening I took away her eggs and gave them to another hen, while I slipped the nine little chickens under her and left her in darkness. Next morning she came off the nest, quite proud of her little flock and taking very kindly to them. I therefore packed her up in a nice crate, and sent her by express prepaid to her mistress, and will leave my readers to imagine her astonishment and delight.

But although the little Bantam-rooster had ignobly perished in the struggle for the survival of the fittest, he had evidently left his impress on the flock. There were several hens of very small size in the yard, and their plumage showed that they were related to him. I therefore saw that if the Bantam eggs I had now setting should latch, it would never do to keep the cocks excejt in a cage or aviary. They did hatch, and I had five pullets and six cockerels. Two of the pullets I kej,t; the other three I pairesl with cockerels, and the little beauties were a source of great delight to some young people to whom I gave them; the three remaining cockerels I afterwards exclianged for birds of a less beautiful but more useful breed. 


\section{(DId Expriences and Niew plans.}

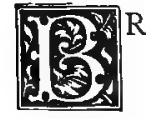

ROWN had never given any personal attention to his poultry: the selection of the stock that was to be kejt was left pretty much to the servant girl, and she thought she was doing a wise thing when sle killed anil cooked the game cock and allowed one of his sous-al larger and more showy birlto take his place. As the mother of this bird was of no particular breel, he, himself, was a mere mongrel, and as he was related, on the father's side, to all the young pullets of that year, the consequence was that the flock lost stamina; and this, and the fact that there was only one cock to over fifty hens, explained the snall hatches-many of the eggs proving sterile.

Now, I had resolved that as soon as. I got fairly under way I would make everything on the place profitable in every sense. If we grew vegetables, they must be the best of their kind and produced at a moderate expense. Carrying this rule into the poultry yard, I determined to procure a good cock from some neiglsbor and put him with half a dozen hens, and so raise a new flock of hens that would be vigorous and prolific. I therefore killecl off the rooster and looked about for another, it lieing my intention to raise a sufficient number of pullets to entirely replace the ol,l stock, with, perhaps, the exception of about a dozen hens, which struck me as being specially fitted for mothers.

I therefore visited my neighbors and examined their flocks, for the purpose of procuring such a bird but, I 'must say, with very poor success. The farmers, as a general rule, had allowed their poultry to breed after a sort of hap-hazard methou; the consequence was that their stock, not being very superior in the first place, soon lecame worse; and I found that Brown's poultry, run -down as it was, was better than theirs. Several villagers claimed to keep pure breeds, but, as a general rule, they were not what I 
wanted, and in many cases it was easy to see that from in-and-in breeding the strain had lost stamina.

At first I felt a little discouraged, and thought my only course was to buy a setting of eggs of some vigorous strain of game birds, and raise a few roosters in this way. Of all the breeds in use the games have been bred upon the most correct principles, and, as a rule, these principles have been rigorously applied. 'I'he result is thit there are liundreds of flocks of game birls throughout the country that bear the same relation to the ordinary birds that thoroughbred racehorses bear to scrubs. 'The breeders of game cocks know that second-class birds are of no use, and consequently those who wish to be successful are compelled to breed for health, strength, stamina aud pluck. And these are the qualities that tell, whether it be in man, beast or bircl. Now, it is well known that there are certain external signs, such as hardness and glossiness of feathers, sinare, carriage, etc., which enable the breeeder of game cocks to choose his breeding birds almost with certainty, while many of the points which the "fancier" estinates so highly he ignores altogether. I felt, therefore, that here at least was ground certain and substantial, and I almost came to the conclusion to procure such eggs. Another motive in this direction came from the fact that I knew by experience that of all fowls the game are the best, both as regards flesh and eggs. A young game cock cannot be equalled on the table-except, perhaps, by a gane pullet; and the killing of a fine pullet has always appeared to me a crime which should be punished without benefit of clergy.

The chief objection to the games is saicl to be their propensity to fight. I have had one game cock in a flock, and his descendants were splendid birds, and as he had nothing to fight with he wis very peaceable. Now, as a single pen of say six hens would furnish all the eggs that I needed for hatching, there would be no necessity for keeping more than one cock, so this objection would be cone away with. I tried to find a good cock that I might use at once, but without success, so I procured some eggs from a noteil breeder and thus hoped to be ready for next year.

Meantime I determined to get a good cock of some other 
breed so as to have eggs for raising chickens at once. What breed should I get?

It is a curious fact that the books tell us very little about the breeding, and especially the crossing, of different breeds of poultry. Even ponderous octavos, which would seem from their bulk to be exhaustive, do not touch upon the subject. I was therefore left to work it out myself as best I might.

It is a well-established rule in breeding, that the male should always, if possible, be a thoroughbred. It is true that in fowls it is sometimes difficult to say what varieties are thoroughbreci, and even the question, "What is a breed?" has elicited long discussions, as witness the nonsense published in the London Field, and quoted approvingly in 'Tegetmeier's large work. There is little doubt but that the different breeds now in market are thoroughbred in very different degrees. The game cock is undoubtedly the most emphatically thoroughbred bird of any that we have, and it will be difficult to find a cock of any breed that will so quickly and clearly impress his own characteristics upon a flock as will a really wellbred game cock 'Tlis quality he evidently owes to the fact that the breed is very olcl, and for ages it has been re-enforcing certain qualities to the exclusion of others, until now it possesses, to an extent not exhibited by any other breed, the power of projecting these qualities into its descendants, even though the mother be of a different stock.

The second rule is, that when two breeds are crossed the hen ought always to be the largest. As a general rule the small breeds are the most finely bred, and have the most highly nervous organization. This holds witls all animals, including man. Who would cross a fine blood mare with a cart horse? The progeny would be worthless. Or a small, fine-boned Alderney cow with a Durham bull, or even with a scrub? While by reversing the cross and putting a large well-formed mare to a thoroughbred, a most useful animal would probably be the result, and a fine Alderney bull of a good milking strain, will probalsly produce a calf that will grow into a first-rate milch cow, even though the mother be a coarsely bred animal. And yet I have seen men who would not have violated 
these principles in their-horses and cows, and yet would put a Brahma, Cochin or Plymouth Rock cock amongst a flock of halfblood Leghorns or Hamburghs.

Previous experience had taught me the value of these facts and principles, and I determined to secure a purely-bred cock of either Hamburgh, Leghorn or Black Spanislı, and mate biin with six of my largest and best hens.

If I lrad been smitten with the "Hen Fever" I would have been a reader of the poultry journals, and would soon have found out where my wants could be supplied; but as it was I had to hunt about for information as to where such a bird could be found.

One day $I$ heard accidentally that there was actually a poultry farm near a village about seven miles from my place, and that the owner had several different kinds of pure-bred fowls. With the usual exaggeration of ignorance, my informant told me that he bad all kinds; that he had thousands of chickens of every kind that could be named, and that he got enormous prices for his eggs and chickens, with much more to the same purport. I did not have a great deal of faith in the details of this account, but having nothing special to do that afteruoon, I harnessed up Madge and (lrove out that way. It was a road over which I had never travelled before, but fortunately there was little opportunity to go astray, and ere long I found myself near the village and opposite what appeared to me to be extensive greenhouses. Inquiring of a passer by where the poultry yards of $\mathrm{Mr}$. Thompson were situated, I was told that these gliss structures formed part of his establishment, and of course $I$ at once tried to find the owner. I hesitated at first whether to make my errand known at once or not. I suspected that if I told him that I had driven seven miles for the sake of buying a rooster he would conclude that I wanted the bird pretty badly, and he wonld clsarge accordingly, sn I said that I had been. taking a drive, and having heard that he had some fine poultry for sale I had called to look at it-all of which was strictly true.

$\hat{I}$ found that he had some very good poultry on hand, though he had disposed of most of his stock, having concluded to give his whole attention to a new breed that had recently been brought 
out-the Plymouth Rocks. He was quite genial and communicative, and showed me freely over lis yards, especially when he found that I was not a dealer. He also gave me a history of the place and of his connection with it, a condensation of which will no doubt interest my readers.

I learned that the place had not bei mnged originally to lim, but that he had merely adapted the buildings, etc., erectecl by a former owner. This I was glid to hear, as it relieved from the stigma of ignorance or stupidity a man who was evidently intelligent and well informed in regard to poultry, and the buildings and arrangements were evidently not those which an experienced poultry breeder would have adopted. It seems that a few years previous to my visit, the place had belonged to a tailor whose business had been just sufficient to give lim a subsistence. This man was obliged to take, for a trifling debt, a small tract of rather poor land, a piece of property which did not add to his income, but, on the contrary, tended to make him "land-poor," as the expression is. But, by one of those strange tums of fortune (which certainly may be called luck) some large manufacturing establishments were erected near it; they extencled until the tallor's property became a necessity to them, and he was enabled to obtain his own price. With the several thousand dollar's now in his possession, he looked about for an investment, and as he was disgusted with the tailoring business, he determined to go into something else. Like many other men, during his dlays of poverty and struggling he had often turned his eyes toward some of the smaller rural pursuits, and chicken raising lad taken a wonderful hold of his fancy. He already had a few dozen fow Is, from which he derived great comfort and profit, and the gollen promises which the possession of a few thousand of such money-producers seemed to lay before him, had often formed the subject of his day dreams, and had frequentiy consoled him in days of dirk adversity. No woncler, then, that when his barren acres had been converterl into gollen nuggets he thouglit he saw an opportunity for the realization of all his hopes. Four acres of land on the outskirts of his village happened to be offered for sale at a very low figure; he bought them and erected the extensive glass 
structures which had attracted my attention. Unused to building contracts and undertakings, he made the common mistake of laying a foundation larger than he could cover, and by the time his houses, etc., were finished, his capital was nearly exhausted. But, he persevered, bought several thousand fouls (three thousand, I think it was) and obtained his food, etc., for them on credit, in the firm faith that the eggs would more than pay for everything. On his little yard in the village, he had kept twenty or thirty hens in a small inclosure, but, then they were fed on a great variety of food, much of it waste from the household, and they were allowed an occasional rum through the entire lot, so that they throve very well. When the same dense fowl population was transferred to small coops, with no opportunity for an occasional run over a larger area, and where they were fed on grain, and nothing but grain, day after day, they soon ceased to lay eggs; the outgo continued but the income was cut short.

Moreover, the great extent of glass roofing on such a small place (for four acres is a very small chicken farm) prevented the utilization of much of the ground for culture and plant growth, and these are always essential. The enterprise was a failure; the feed bills became due, without any means to pay them, and the sheriff closed out the entire concern.

The preseut owner had begun in a different way. Possessed of a small independent income, but afflicted with an incurable disease, he had taken up poultry keeping as an amusement, and had devoted his attention to pure-bred fowls-chiefly the Light Brahma. These he had so improved and cared for that his birds became noted amongst his neighbors for their excellence, and he found a ready market for all the eggs and chickens he could supply. At first his prices were very low-merely the retail market rates, but having been induced to send some of his fowls to the county fair, he was awarded the first prize, and then, orders poured in faster than he could supply them, and with offers of greatly advanced prices. So he raised his terms, from fifty cents per setting, to $\$ \mathbf{1 . 0 0}$, and then to $\$ 1.50$, and $\$ 2.00$, and still he could not meet the demand. His poultry became a source of income, and when the tailor's 
place was sold he bought it, intending to rebuild the houses and rearrange the whole affair. But when he had obtained possession he found that the buildings had been put up by carpenters who had followed the desigus given in the books, and had not been guicled by a man of extended practical experience in poultry keeping. So he arranged part of them as breeding houses for raising young chickens, and some of them he rented to a neiglabor who used them is greenhouses. This neighbor had a small peach orchard of about five acres, adjoining the poultry yard, so he gave Thompson the right to pasture his chickens in this orchard in exchange for the privilege of using the greenhouses-a most judicious arrangement for both.

Thompson's business now became lärger than ever. He soon became known to certain city dealers who had a wide connection, and they bought from him large numbers at very remunerative prices, because they knew that they could depend upon every bird being strictly as it was represented. After a while he added other varietics to his collection, being alvays careful to maintain the strict purity of his stock. At present he had White and Brown Leghorns, Spangled Hamburghs, Black Spanish, and he had just received a new breed which has since become famous-the Plymouth Rocks. These facts I gathered partly from his own lips and partly from subsequent information from others, but so well was I impressed with the sensible, and apparently honest character of the man, that I did not hesitate to explain to him what I wanted and to ask his advice.

After showing me over his yards and explaining his methods and describing the characters of the different breeds, he led me to a small yarl where, in a series of separate pens, he had about twenty of the most beautiful Brown Leghorn cockerels I had ever seen. These he recommended as the best birds for my purpose. Mated with good common stock of fair size he guaranteed that they would produce clickens which would give satisfactory results both as regarded eggs and flesh. As, his price seemed-very moderate- $\$ 2.00$ for a cockerel, I paid for one, had it put in a light crate and took it with me. These crates were quite ingeni- 
ous, being simply a frame covered with very cheap bagging on sides and bottom. 'The top was made of slats and after the bird was put in, these were fastened with nails. Thompson kept these crates on hand ready made, and he told me that they were so cheap that he could afford to give one with every bird he sold.

As I clrove home that afternoon I could not help thinking a good deal about what $I$ had seen and heard. I had always been a reader of the journals devoted to country life, and was fully aware that the attempts to raise poultry on a large scale had been numerous, persistent, and in many cases carried out with great intelligence and enterprise, and with abundant capital. And yet, so far as I then knew, all these attempts had failed, and I have not learned to the contrary yet.* And the question then arose and pressed itself upon my attention: Is failure a necessary sequel to all such attempts? It argued, of course, even to my own mind, that I had a good deal of self conceit when I decided that success could be attained; that there was no absolute obstacle in the way, and in all the plans that had come under my observation I could see that there were glaring defects that must of necessity cause failure. Some had failed because their quarters were too cramped. I called to mind one man-and, strange to say, a medical man at that-who attempted to keep nearly 300 fowls on a space that should barely have accommodated ifify. $\mathrm{He}$ was thorougilly "scientific," and fed his fowls on rations whose composition was determined more by chemistry than by common sense, and he failed.

Another, a business man in a large city, felt that he nad a call to raise poultry and eggs, and so he established a poultry yard. But although (perhaps this word should be because) he purchased liberally of all kinds of food, and procured fowls that were the very best that the dealers would recommend he failed, and the reason was obvious. He knew nothing about poultry, and could not meet emergencies as they arose, but supposed that a hen was a machine,

\footnotetext{
* Since the above was written we find in a recently published work-Beale's "Profitable Poultry Keeping" - the following statement: "There is little talk now of establishing poultry farms pure and simple, which never have, and we do not think ever will, succeed."
} 
and that all you had to do was to wind her up three times a day with a little corn and the eggs would roll into the hopper.

These are not imaginary instances, but actual cases. Of minor instances the number is innumerable, and I myself have known at least a dozen people who have been smitten with the hen fever and have sunk money. But all this did not fully convince me that poultry could not be kept, or that $I$ could not keep it profitalsly.

I have been told that in the famous "Warwick Woodlands," so well described by Frank Forrester, there is a poultry firm maniged by a colored man who keepes 3,000 fowls and makes a handlsome profit. There is also the poultry establishment of Mr. Baker, in New Jersey, in which eighty thousand dollars have been invested in houses, incubators, etc., etc. In regard to the financial success of this enterprise I' am not informed. 'The gigantic establishments of De Sora, Don San Fuentes, etc., etc., so graphically described by Burnham, Lewis and others, are mere mytlss, and have no existence.

Looking back over an experience of many years I could recall my first acquaintance with the poultry yard, where the hens were always a source of reatly money at times when other crops were not available. Ant even now I could recall from that long-past experience facts and methods which seem to be forgotten, and yet are well worthy of being kept in use. In those dilys there were no stolen nests-no lost eggs, and yet our poultiy had free range over many acres-those places from which they were to be excluded being carefully fenced so as to keep the poultry out. Well do I remember how we depended, with a trust that I never remember to lave been betrayed, upon the hens returning to their own roosts at might. Although they numbered some hundreds, and during the day spread themselves over a wide expanse, they always returned at eventide. In those days no laying hen ever left her house in the morning until she liad laid her egg It is the easiest thing in the world to tell whether or not a hen is going to lay an egg during the next twelve hours; and well do I remember out old hen wife examining each hen, and letting those without eggs go, while those that were going to lay. were kept in. When a small 
boy $I$ used often to be pressed into the service of catching the hens in the hen house during the operation of "trying the hens." And the hens being always kindly treated and frequently handled were not clifficult to catch.

'Then, I renember, how, years ago, when we first went to housekeeping in our own home, we resolved to have fresh eggs for our table, and not be disgusted with occasional stale eggs, which prevented all further enjoyment of that meal. And so I made a small house that two men could easily carry about, and with portable fencing, almost the same as that described in this book, I made a small yard in which I kept half a clozen Light Bralıma pullets, that kept us in eggs nearly the whole year round. And, I had not forgotten the success with which I raised some of the handsomest bircls that had been seen in that locality-birds, to which people walking past our city lot, would give no mere passing glance, but would stand still to admire. This was the first 'instance I had ever seen of a movable coop designerl to enable us to give the birls fresh ground whenever we desired to do so, and to raise crops on the soil which they had at the same time both enriclsed and defiled.

These things I looked back upon with pleasture. Not thit they had been very profitable-they were on too small a scale for that-but, because I felt that I was not without a certain familiarity with the subject, and, consequently, I would probably be able to steer clear of any glaring mistskes at first.

Such thoughts occupied my mind as we jogged along, and I suppose Madge often wondered why her old master did not kcep a tighter rein, and watch for her stumbling. It was dark when I got home, so I put the little rooster in Madge's stable and left them for the night.

During my waking hours, poultry occupied ny chief attention. The barren soil along the cliffs; the unoccupied land on the east, the use of which I could have for the asking; the necessity for something to profitably occupy my time and effort, all passed hefore me in vivid and earnest thought. I saw the uselessness of this land for everything else, and its great value for a poultry range, 
and the idea impressed itself upon my mind that, while poultry keeping could not be expected to leat to fortune, it might afford a very pleasant and very efficient means of anding to a slender income. But so much had been attempted in this direction, and always with failure, that, after all, I could not help) regarding the project wilh a good deal of cloubt. 'The "hen fever," the "poultry craze," and the "chicken mania," well-known forms of speculative dementia, had ruined thousands, and therefore I resolved to banish it from my mind. With this I fell asleep, and when I woke the sun was shining brightly through my bed-room window. 


\section{Orning to Improve the (D) Stock.}

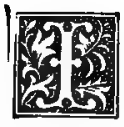

IV-AS up betimes next morning, and my first errand was to the stable, where the new cock hald been left. I found him roosting quietly on the side of Madge's stall, and as he rose up when I entered, I got a very good view of him. I could see that he was just what I wanted. Plump, yet not logy; clear eye, and bright comb and wattles; firm, bright, springy feathers, that felt wiry, yet not harsh-just the opposite to the soft fluff that hangs round the necks of weakly-bred fowls; bold, erect carriage, seemingly fearless of anything. $\mathrm{He}$ was just the bird I had been looking for. I knew little about "standard," and cared less; a "Judge" might have cut down his "points," so that he would not score "40". out of a possible " 100 ," but according to my way of judging loe scored over " 90 " at least, and, joking aside, I believe he was a good bird, even according to the standard; for, as I afterwards learned, Thompson's stock was noted amongst the dealers for careful breeding. From my talk with him the day. before I found that he was a judicious, conscientious breeder, and that I ran little risk of getting a bird with a bar sinister on his escutcheon. And this is an important point, for crosses are very apt to crop out in after breeding, while so various are the different shades of plumage of dunghill fowls, that amongst even common birds some are occasionally found that show many of the points of thoroughbreds. But while these individual birds may show great excellence, their progeny are sure to be mixed in color, and with every variety of shape and quality as layers and meat-producers.

Some of my friends were a little surprised that I did not select a larger breed, so that by crossing with some of my large hens I could get good-sized fowls for the talle. But my experience had been that the size of the cock is not of so much importance. Some 
years ago a friend had a game cock which he did not wish to part with, and yet could not very well keep, so he let me have the bird for a time. He was a rery handsome, vigorous fellow, but smallless than 5 lbs. I mated him with some hens that were part Brahma, part Dominique, and looked a good deal like the Plymouth Rocks of to-day. They were fine large hens, and the progeny of these fowls and the game cock were very handsome and very large. Most of them had pencilled necks, and looked like what are sometimes called "Pheasants." Others were of various colors, but all were well-shaped, vigorous fowls, and the pullets proved to be good layers. The cockerels were heavy and of delicious flavor. The finest became the pet of our servant girl, and as she had taken great care of the poultry I allowed her to keep him, although against my better judgment. At two years old he weighed $12 \mathrm{I} / 2$ pounds, and was universally admired for his fine logks, but his progeny (althougl breeding in-and-in was carefully avoided) were very inferior to the chickens of the previous season when the game cock was at the head of the yard.

Now, the Brown Leghom is as nearly a thoroughbred as can be had, and as this breed is noted for laying qualities I felt certain that my choice had been a judicious one. But, like many other men, I had secured the bird without having a place to put it. 'To have let him loose amongst the large flock of hens would have ruined him and do:se the hens very little good. Where could I put him?

In one corner of the barn was a small room which had been used for a storeroom, but was now empty. It was about ro feet by $\mathbf{1 2}$, with a good-sized window. So I sent to a saw-mill for a barrel of saivdust, with which to keep the floor clean, provided troughs for food and water, nests for the egg layers, and placed a stout pole, about 3 incles in diameter, across one corner as a perch. With my present experience I would not have used sawdust, but would have taken dry sand, which is far better and muclı cheaper, as it can be had for the cartage. Dry eartl is better still on brick, stone or earthern floors, but on wooden floors it is apt to produce decay, since, no matter how dry it may be when it is put in, the 
bottom of the bed of earth will become damp, and in time will rot the floo:.

The nest boxes were simply small packing boxes, not less than I 2 inches in any dimension. They were prepared by removing all the top or covers except about 3 inches at one edge; this was firmly nailed on, and when the box was laid on its side the strip 'formed a ledge which kept the straw and eggs from rolling out. Such nest boxes are cheap, easily moved, easily cleaned, and, when set with the opening about ten inches from a wall, they afford that secrecy which hens love so much.

Meanwhile, the hens in the large poultry house had been kept shut up all morning. I now examined them, selected three that I thought would mate well with the Brown Leghorn, and placed them in the room I had fixed up. As there had been no cock in the large yard fọr over two weeks I felt pretty sure that any chickens that might be hatched would be the progeny of the Brown. Leghorn, and I also knew, from former experience, that after these hens had been with the Leghorn for a week the eggs would be fertile.

The next step was to prepare a proper coop out doors. On the place was a packing case which had been sent from the city with an organ. The organ had been sold by Brown just before he moved away, and was purchased by a party in the village, and as the case was not needed for such a short journey it was probably forgotten. At any rate it was mine now, so I removed the bottom and used the boards to increase the height of the case, and with a little extra lumber I soon had a very comfortable little house, amply sufficient for seven hens and the rooster. The door was a small affair, just enough to let a good-sized boy or small man creep in, but as the eggs were reached from the outside, and as the house was never cleaned except by moving it, a door was perhaps not a necessity.

The next thing was the fence. I made several lengtlss of portable lath fence, the same as that hereafter described, and enclosed a space 32 feet long and 16 feet wide at one end, and 16 feet and the width of the house at the other. The hens were large, with a 
good deal of Brahma blood, so that a low fence easily kept them in: but the cock would have required a ten-foot fence, and, indeed, I doubt if even that would have confined him against his will. So I just shaved off the feathery part from the quills of one wing, and after that the height of fence necessary to restrain him was limited by his power of jumping, and which, by the way, was by no means contemptible.

It dicl not take long to get the new house in order. Isaying plans and getting material,consumed more time than dicl the actual work, but on the evening of the second day we had the three hens first selected, safely in their new quarters. As they had been two days in company with the cock I was satisfied that the eggss would snon prove fertile, so I selected two more hens and placed them in the storeroom, and next day I added two more, thus making seven breeding hens in all. On the fifth day I placed the cock in the out-door coop with the three hens first selected, and as soon as the hens in the storeroom had laid four eggs each, I placed them in the coop and gathered all the eggs for hatching.

The time which it takes to produce fertile eggs depends, of course, upon circumstances. If the hens are not laying, and do not lay for a week after they are with the cock, then every egg will probably be fertile. -But if they are laying, then every egg that is developed to a certain extent will be sterile. After the fich egg it is safe to depend upon them. These hens were all laying. This is an easy matter to determine, and we took care to examine the hens before selecting them. During the first seven days we got thirty-five eggs from the seven hens, and these we used for cooking. After that we set the eggs as fast as circumstances would permit.

Sulsequent experiments threw this little venture entirely into the shade, lut it may not be out of place at this point to give the reader the results, and this I am able to do, because I kept this little flock and their progeny separate for several seasons, having regarled it with a good cleal of interest, since it might be supposed to serve as a test of the correctness of my plans and theories.

My object at this time was merely to establish a new flock of about fifty hens for my own family use, and perhaps the sale of a 
few eggs and chickens every year-the sales being expected to offset, to a slight extent, the money actually laid out for feel, etc.

As already stated, I had only one rooster-the Brown Leghornand on taking stock $I$ found that $I$ had just 57 hens. After selecting seven for breeding purposes this left exactly fifty for laying. Most of my neighbors would have had five or six roosters wilthese heus-a useless expense, as I have found that hens lay quite as well when alone as when with a rooster.

By confining the attention of the rooster to seven hens, the birl was not exhausted and enfeebled, as he woukd have been if he had been put with the whole flock. The eggs were therefore more likely to be impregnated, and the progeny more certain to lie vigorous. I have found, by experiment, that a single attention from the cock is just as good as a dozen, and perliaps better, provided he is in vigorous condition. Weak chickens do not come from the fact that the hens have not had attention enough, but from the fact that owing to too many efforts in this direction the vitality of the cock is lowered. Of course the influence of the cock disappears after a few days, and must be reliewed, but while it lasts there is no diminution of its potency.

By selecting choice hens, and breeding, only from them, I was enabled to control the kind of chickens $I$ should have, and by keeping them in a coop by themiselves I lost no time selecting eggs and trying to find out which hens laid them. It may be possible for a poultry keeper with five or six hens to distinguish the eggs of each individual birl, but where there are thirty to fifty this becomes impossible. By keeping the breeding hens by themselves all trouble in selecting eggs is avoided.

'Ihe result of the experiment.was all that I could desire. We set the hens of the main flock as fast as they became broody, and in a little while we had quite a number of young broods scattered over the place. Some of the breeding hens wanted to set; we gave them eggs and let them bring out their broods. Meauwhile, four more hens were selected from the main flock and shut up with the rooster in the room first prepared. After two days he was returned to the out-door-flock, which was now reduced to four, and again, 
after two more days, he was replaced in the small room. Two days after that he and the hens were placel in the out-door coop. The chickens from this cross showed wonderful uniformity. Nearly every" one had a pencilled neck, the feathers being reddish with a black stripe down the centre. The bodies of the birds were a dark reddish-brown. In shape they were excellent-legs not too long and plenty of breast. They matured early, and the pullets were most prolific layers. A few showed a most decidedly dung-hill origin, evidently luaving "cried back" to some long prior ancestor.

Altogether we set 37 hens and raised 27 I chickens-an average of a little over seven to each brood. S'me poultry keepers will probably thiuk this a poor hatch, but the reader must remember that many of the setting hens were small, and not very good mothers. Of these I 57 were cockerels, which we killed, and either used or sold, and I I4 were pullets, of which go were considered good enough to keep. At the close of the season we sold most of the hens that were in the old house and yard, together with the 24 culls. The price received was quite satisfactory, and in this way we got rid of all this old stock. In the winter we placed the go young pullets in the house, but without any rooster. As they were late birds they did not begin to lay as early as we would have liked, but they continued laying all through the summer months, and, in order to see what the result would be, we selected seven of the best, mated them with a Brown Leghorn from another yard, and raised enough chickens to supply us with fifty good pullets. These pullets were three-quarter Brown Leghorns, and showed their origin very clearly. They were smaller than their mothers, but were good layers.

It is astonishing how rapidly a cross can be brought back to any breed simply by using thoroughbred males. Thus-

The first cross produces half-bloods.

The second gives us three-quarter blood.

The third produces seven-eighth.

The fourth produces fifteen-sixteenths.

The fifth brings it to thirty-one-thirty-seconds, which is so nearly pure bred that few people can tell the difference. 
My experience, is, however, that after the first cross the $\cdot$ purer the progeny is the worse it is, until we pass the fifth, at which point it again begins to improve quite rapidly.

The cross between Brown Leghorn and orcinary speckled hens is most excellent in every point except one-lhe plumage is a little too dark for a market bird-and as fully half our young stock will be sold either dressed or to be killed, this is a very important matter. I feel now that it would have been much better to bave selected a White Leghorn cock, but as the question of marketing did not occur: to me at this stage of my experiment, I made the selection I did.

In selecting the hens I had tried to pick out those that had just commenced laying after having been broody. 'There were several of this kind on the place; some we had "broken up," others had brought out a few chickens, which had been taken away and united with other broods, and of some the chickens, from weakness of constitution and want of care during Brown's moving, had entirely disappeared. I do not regard it as a settled point by any means, but I an inclined to believe that the eggs laid by a hen just before sle wants to set never produce quite as strong chickens as those that she lays previously.

I have always had a fondness for a lot of chickens uniform in color, and yet, perlıaps, I have been less successful in securing this. than olher breeder that I know of. Brown's chickens were of all sorts, sizes and colors; pure black and pure white; mottled, red, percilled necks, and so on to the end of the list. It was with great difficulty that I was, able to pick out four or five hens that were 'anyway nearly alike, but I thought that next season, seeing that I must have a goodly lot of chickens from the same mother as well as the same father, I would be able to pick out seven pullets for breeding; and by gettiug a new cock from some other yard, so as to avoid in and-in breeding, I would be able to gradually build up a flock that would do me credit. And here let me say a word about breeding too closely. I am perfectly well aware that a new breed cannot be estallished without very close in-and-in breeding. This has been the practice of all the great poultry breeders, and it 
has held equally in other departments-even in insects. In the "Dictionary of Practical Apiculture" I find the law litid down very clearly under the word "Breell." The author says :

"In attempting to establish a new breed or to improve an old one, we must, contrary to the usual opinion, pursue a releritless system of breeding in-and-in, and it is here that the skill and judgment of the expert breeder will be most fully shown. We have on the one hand the danger of weakening the constitution of our stock, and on the other, the danger of producing a lot of mongrels without any fixed characteristics. The experience of all great cattle breeders has shown that it is only by in-and-in breeding that the tendency to "cry back" can be eliminated, and these men lrave also shown that when sufficient care is exercised in the selection of the breeding stock, the danger of weakening the constitution is not to be feared. In this connection it should be remembered that all the well-marked native races of bees must have been produced by a series of in-and-in breedings, combined with a system of natural selection, which allowed the survival of none but the fittest-all the weak and nou-prolific, and all the poor honey-gatherers being killed off during severe seasons. It is the same here as witl the great herds of cattle and horses which roam at large in various countries. The most powerful and active bull or stallion obtains the leadership of the herd and breeds in-and-in with his own cousins, sisters, and even claughters, until one of his progeny, more powerful than he, displaces, him in turn. But here we have the weak and feeble calves and foals selected by the forces of nature with better jurlgment than ever man exercised, and killed off by the inclemency. of the weather as surely as ever butcher's knife dul its work."

But my object was not to build up a new breed, but merely to improve an old flock. Therefore I could not afford to make such a study of my birds as would enable me to work out such matings as would successfully counteract the evils of in-and-in breeding. Bu: so far as mere uniformity and excellence of the individual birds were concerned, my success was all that I could wish. By using 
the purest Brown I.eghorn males that I could.find, I kept giatually getting nearer and nearer to pure Brown Leghorn hens, with this disadvantage, that I could not sell their eggs for hatching. It is true that they were slightly larger, and more hardy, than any thoroughlured fowls of their kind that I could get, but, on the other hand, they were not as large as a first cross between Leghorns and Brahmas, or Leghorns and Plymouth Rocks. After the fifth season I discarded them entirely, and sold them to a farmer who wanted Brown I eghorns, but did not care to give the price of thoroughlseds. How they will turn out in his hands remains to be seen. I understand that he is taking.great pains with them, having set off four pens which he keeps enturely separate, and uses cockerels from one, and pullets from another, for breeding, so as to avoid, as much as possible, all very close breeding, and thus keep the strain pure and in all its vigor.

For myself, for reasons which I have fully explained, I have abancloned this cross, as well all crosses from pure bred females. I get better results from females of mixed blood, than from those that are pure, but in all cases the males must be thoroughlored. The potency of the male in transmitting the qualities of his breed is in exact proportion to his pedigree; if mated with a hen. of equal potency it is difficult to tell what the result will be; sometimes the hen, and sometimes the cock will govern the character of the progeny. Use hens of less potency-tluat is, less purity of breed; in other words, use cross bred hens, and the character of the male will be more fully developed. 


\section{fucts and fancies.}

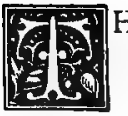

HE balmy days of June were fully upon us, and as I sat one evening watching the increasing rows of brooding coops with their tiny population, I could hardly help' dreaining of the future possibilities which they enfolded. I harl already fully discussed in my own mind, the subjects of truck farming, or gardening; of the keeping of cows, and selling milk; of the raising of small fruits, and of some other branclies of country work which I thought might help me out, but, after the most thorough and fair consideration that I was able to give them, I was compelled to decide that they would not suit my purpose. At the sight of so many young broods, I again reverted to poultry-keeping, and could not help running over in my mind the ordinary calculations upon which the profits of this business are based.

The usual calculation is, that a hen can be supported for one dollar a year, and that, if of a good breed, she will lay twelve dozen eggs, which sell at various prices from 20 to 60 cents per dozen. Assuming an average of 35 cents, the twelve dozen would bring $\$ \mathbf{4 . 2 0}$, leaving a profit of $\$ 3.20$. The manure, etc., is supposed to offset the labor and interest on house, etc., and as the hen may, in addition to all this, raise a brood of chickens, it is argued that the profit ought to be quite equal to the amount named. Now, it seemed to me tliat, if this were anywhere near correct, people woukd have found it out long ago. Still, it no doulst requires skill, tact and knowledge to produce such a result, and it is not every one that can command these. But, the point which impressed me most strongly was, that if there was any basis of fact in these calculations, then 235 hens ought to yield $\$ 75^{\circ}$ yearly, the amount I needed to make ends meet, and as I liad already on the place nearly half as many liens and clickens as was demanded, the fact stared Ine in the face, that, with very little more expense and labor, the experiment migitt be tried. 
I doubted the accuracy of both the elements of the above calcula. tion, however. I suspected that no hen, even of the smaller breeds, could be supported on one dollar a year, uniless under very special and fivorable circumstances, and I also cloubted the amount of the receipts. An average of ten dozen eggs from each hen of a large flock, even with a judicious selection of the birds, and with very excellent care, would be as much as could be expected. I had myself realizerl more than this, but the flock was small and exceptionally good. Allowances must be made for sudden invasions of disease and accident, but these I did not greally fear.

But, even at these reduced estimates, the profit ought to be considerable, and 250 fowls is not by any means a number beyond what can be easily handlecl. Three, or at most, four houses, would accommodate them, and the labor would not be more than could be spared from other things by the hauds alrearly on the place.

My first thought was to see what others had accomplished in this direction, but the records were very meagre, many of the most important data being omitted. I could find only two books in market that professed to describe the best systenis and methods of managing large numbers of poultry, one being the "Poultry Breeding Lin a Commercial Point of View," by Geyelin, anet the other, "An Egg Farm," by Stoddard. Geyelin's system was altogether too artificial for my purposes, and as report said that it had not proved a-success in the hands of the originator, I did not feel very much encouraged to adopt it. Neither was the system described by Mr. Stoddard arlapted to my circumstances. The extent of ground and "plant" necessary to fully carry out his system was more than I could command. Moreover, I nerer could quite make up my mind that the systen described in that book had been actually carried out in practice. It always seemed to me that $\mathrm{Mr}$. Stoddard harl "evolved it from the depths of his inner consciousness." And, indeed, the chief point upon which the system is based, viz., the alleged fact that hens will not stray far from their own homes unless led away, contradicted my own very emphatic experience, for my fowls have often wandered away to a distance quite equal to half the breadth of his farm. 
Now, it so happened my wife had kept accurate accounts of all our income and outgo in regard to the hens, and although the conditions were not quite ths same as now, yet they were sufficiently so to enable me to get at the figures I needed.

I found that in former years it had cost \$r.25 per bird for the year's sustenance. But, in this case, the cost had been diminished by various little items, such as waste from our own table, etc. But, as we had previously bought all the food, whereas now we could easily raise a considerable portion of it, these two differences might perhaps be allowed to offset each other, and I therefore put down \$I.30 as the cost of keeping one hen in food for a year. The receipts from eggs alone ought to be at least ten dozen eggs at 30 cents per dozen, which would be $\$ 3.00$, and this would leave $\$ 1.70$ for labor, interest on houses, fences, etc., and for profit.

So far the calculation was quite simple, and the data not difficult to get at, for even if I had had no recorl it would not have been difficult to tell what it cost to keep for a week the seven hens and a rooster which I had now cooped up, and then a very simple sum in arithmetic would have given me the information I needed. But when it came to the cost of housing, attenilance, range, etc., the exact figures were not so easily gol at. A dozen or twenty fowls may be housed by means of makeshifts which may be said to cost nothirg, because even the labor is merely pastime, and the attendance is mere amusement. One thousand fowls cannot be cared for in any such way, and I had no data, and dicl not know where to look for any. Geyelin's work is very explicit on the subject, but the conditions are very unusual, while Stoddard is singularly deficient in those statements of time and cost which are so important in a matter of this kind, and which are so apt to creep into a record of actual experience.

After much thought and figuring, I came to the following conclasions:-

I. That if the cost of housing and attendance were left out of the calculations, - I could make a clear profit of $\$$ I.7o per hen.

2. That with my present help and facilities, I collt take care of about 250 hens and their young. To do this work there was 
part of the time of one man and a girl, and so mucl of my own time as was not occupied with the oversight of the rest of the place, and such other calls as are usually made upon a man in a similar position.

3. My present accommodations would enable me to care for about 125 fowls.

4. That by hiring a good, steady, elderly woman, who would give all her time to the fowls, I could easily increase the number to I,000 birds. I proposed to oversee and direct; as well as to aid in actual work; the man would do the heavy work, and the girl could find time for a little general assistance, and as she was very much interested in the hens and clickens, she was always very willing to do so.

These points being reached, several important questions presented themseives, amongst which were the following:-I. How many birds can I keep successfully on the land that I have available for such a purpose? 2. How much extra house room must I provide? and, 3 , How should I arrange the houses and yards?

I calculated that the paddock must be reserved for the horse and cow; one acre was already devoted to asparagus, so that this left about two acres of arable land, two acres of shrubbery, and half an acre of orchard, making about four and a, half acres, to which might be added the barnyards for the older fowls in winter, and the lawn for small chickens in summer. How many chickens could I keep in this space?

Upon no subject did I find such great diversity of opinion as upon the extent of ground that should be given to the flocks-in other words, in regard to their range. The author. of the "Egg Farm," allows $62 \mathrm{I} / 2$ acres to 5,000 birds, which is at the rate of 544 square feet to each bird; Wright, the author. of "The Practical Poultry Keeper," in his own yards, allows 44 feet to each bird, and tells us that they thrive well. He also tells us that he has known of "fowls" being kept on a space of 12 feet by 3 . This is at the rate of $3^{6}$ square feet for several birds-say 3 to 5 -or with an allowance of from 12 to 7 square feet for each.

Geyelin in his "Poultry Breeding in a Commercial Point of 
View," describes his "poultry homes" intended for 6 hens ancl I cock, for breeding, or I 2 laying hens, as being 2 I feet by 3 . This is 66 square feet to $\mathbf{2} 2$ heus, or $5 \frac{1 / 2}{2}$ square feet 10 eacls bird.

Warren Leland, a very successful poultry keeper, allows four and a half acres of land to each thousand birls. 'l'his is at the rate of 196 square feet to each bird.

'The editor of the Massachusetts Ploughman allows 6 acres of rocky land to each 1,000 birds. This gives 261 square feet to each bircl.

In former years I had kept twelve birds in good health and unusual productiveness in a yard 16 . feet long and 8 feet wide which gave very little over 12 square feet to each bird. It is true that they were given the liberty of the whole garden occasionally for a short time, and this would of course break the monotony and enable them to gather iusects, etc.

Allowing roo square feet to each bird, an acre would serve for 435 fowls, and this seemed to me to be about the right amount to secure health and contentment. On this basis, I ought to be able to keep at least 2,000 fowls on my pliace-about twice the number that I at present thought of keeping. So much the better for the fowls.

As my present accommodations were fittel for at least 125 fow]s, about 8 times the present amount of house-room would be required, and this was perhaps the most serious question of all, because it concerned an investment which would prove an almost total loss if the enterprise should prove a failure. Land could be devoted to other purposes, and fowls could always be sold for nearly what they cost, but clicken houses, would be worth just so much kindling wood, and from even this value must be deducted the cost of chopping them up. My next step, therefore, in making my calculation was to fix upon the arraugement of my yards, and the number of birds in each house.

I searched carefully the records of what others had done, chiefly with a view to finding out how many hens had been successfully kept in one house and yard. I found plenty of descriptions of houses 
calculated to hold from one hundred to three hundred fowls, but no account of the success with which the birds bad been kept. I was, therefore, compelled to fall back on my own experi-. ence.

Turning back to my earliest memories connected. with poultry, there was presented to me a most distinct mental picture of a rough poultry house in which over one hundred birds found a nightly lodging, and in which they laid their eggs. They throve well; I never remember to have seen disease among them; eggs.. were abundant, and the labor of caring for them was not very great. During the day they wandered over a large area. of farm land, but always returued at night.

Coming down to later years, $I$ had in mind a former poultry yard of my own. We had a house which accommodated about fifty hens very nicely, but we raised about two hundred chickens from which we saved filty pullets, and for these, quarters had to be found elsewhere. We put ul a cheap loouse of rougl boards, battened, and kept them in that. They laid well, maintained good. health and prover quite profitable. But the special lesson which this later experience taught me was, that, although the two flocks wandered over the entire place (about $3 \frac{1}{2}$ acres) and mixed with each other freely, they always returned to their own houses to roost and to lay, and no quarrels were ever occasioned by the two different sets coming in contact.

I felt sure therefore that I could place as many houses as I chose on the grounds with seventy-five birds to each house, and that so long as the general range was sufficiently extensive I woulcl find no diffculty. I therefore fixed upon, seventy-five hens as the number which my houses ought to accommodate, and resolved" to build one, intending to add house after house, until I had as many fowls as I wanted.

And thus, after much thought, and no little actual work in inves. tigating the subject, I came to the conclusion that in my peculiar circumstances, aid with my tastes and training, poultry was the only rural employment that offered a way out of the difficulties that beset me. 


\section{Working (1) ant a Spgtem.}

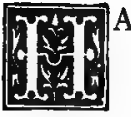

AVING decicled to make the attempt to add to my income by the keeping of poultry, I set resolutely at work to arrange my plans, and work out a thorough system, so that success might be assured with at least a reasonalble degree of certainty.

It was my purpose to have ultimately in my yards $r$,ooo laying hens. I concluded to dispense with cocks, as an expensive and useless addition, so far as these hens were concerned. Of these I,, 00 hens, I intended to have, on the first of January every year, 500 birds of about nine months ohl, and 500 that were a year older, the intention being to get rid of the latter during the following season, as soon as they ceased to lay. 'This involved the uecessity of raising 500 clsoice young pullets every year, and as more than half the chickens raised would be cockerels, and onethird of the remainder might prove culls, it was necessaly that I shoukd raise every year from $I, 500$ to 2,000 chickeus. Allowing that each breeding hen, during the season in which I wanted to hatch my chickens, would lay 40 eggs, it would be necessary for me to have 50 breeding hens. These would have to be kejt in small pens, of say 6 or 7 each, with a carefully selected cock-requiring about eight breeding pens. Allowing an arerage of nine to a brood I found that I should need about $25^{\circ}$ sitting hens with accommodation for them.

As it was now nearly the first of July, it was too late to do much this season, but after mature delıberation I decided to procure during the next three or four months, about 500 young hens and thus make a fair beginning for the coming year. Next season I intended to raise my full complement of 500 pullets, so that at the end of a year and a half from this time my system would be in full operation. 
The breed that I should adopt occupied my first thoughts, because on this depencled to some extent the kind of houses, coops and yarcls that I should build.

I had had personal experience with Black Spanish, White and Brown Leghoru, Dorking, Light Brahma, Dominiques and mongrels, or so-called barn-yard fowls, but was not quite satisfied with any of them. Still it was upon these that I determined to place my chief reliunce because, I would then know what I was about and all my former experience would be available. My former experience, however, had not been gained under circumstances which led to a very close consideration of the best variety for market, and as my present experiment looked to the market for its success, it was important that I should keep this feature prominently in view, and make no mistake. The following points occurred to me as leing essential :-

r. The hens should be good layers of fair sizenl eggs. The color of the eggs I did not care so much about, because I was. situated between two large markets, at one of which white eggs were all the fashiou, while at the other the preference was for dark eggs. I found that those who preferred clark eggs did so under the impression that they were richer, while those who chose white eggs did so because they looked prettier. I also found that dealers woukl not give any more for one than for the other, though they would buy more freely of tỉe eggs which they preferred.

Now, it was my purpose to secure as many private customers as possible; these I proposed to furnish with eggs direct from my yaris, thus saving all middlemen's commissions, and sending: the surplus to the general market, only when it became inconveniently large. I therefore trusted to the fact that eggs which were guaranteed to be not more than one to three days old would command a ready sale whatever the color.

2. Since a poultry yard of the size of that proposed must depend upon its own resources for raising young fowls, and since fully half the young birds thus raised: would be cockerels; for which the market would : be, the ouly outlet, it was necessary that whatever breed I aclopted should be a good table fowl. That is to 
say, they should mature early, reach a good size, and present a fine appearance when dressed. This excluded all dark varieties, such as Black Spanish, Minorciss, Black Hamburghs, Javas, etc. 'These varieties rarely look well when dressed. On the other hand full grown, and well-conditioned birds of the Light Bralıma variety always look well, but the young birds look "leggy" and poor. 'The Leghorns look well and mature early, but are too small. Dominiques mature early and look tolerably well when dressed. At this time the Plymouth Rocks had not been generally introduced, or I should certainly have used them, as I have since done. In the common strains of this breed, the cockerels are generally light and the hens dark.

And here let me note the absurdity of the fancier's rules, which demand that for exhilsition purposes the cocks and hens ought always to be as nearly of the same color as possible. 'l'o a sensible poultry man, the fact that the cockerels are always light and the pullets always dark is one of the greatest advantages and for these reasous: In the struggle for existence the dark will always supersede the ligbt. White fowls never have the stamina of the dark ones, and perlaps it was a knowledge of this fact which led me to select the Brown Leghom in my recent experiment. Now the dark hens of the Plymouth Rocks, are to be kept for breeders and layers and with them strong constitutions are of the utmost importance especially for winter layers. But, if the cockerels were dark, it would be a great drawback in marketing those that must be killed, and fortunately the cockerels in common strains are quite light.

And let me heie add in favor of the Plymouth Rocks, that they reach a good size, and if reared in a good run, have a most excellent flavor. As layers, the hens do not equal the Leghorns and Hamburghs in summer, though they are quite the eqmals of these famous breeds during winter, and as I have had an average of I37 eggs per year from a flock of thirty Plymouth Rocks, it is evident that they are not so very far behind the best.

-But, not having the Plymouth Rocks that season, I was forced to adopt some other breed, and weigling carefully the good and 
bad qualities of all the breeds with which I was acquainted, I decided for the present to adopt a cross-bred fowl for laying and marketing. The cross that I now selected was that between a White Leghorn cock and a Light Brahma hen. I also resolved to experiment with crosses between White Leghorn and Spargled Hamburgh cocks, and Light Braluma and Dominique hens. Of the cross between the Brown Leghorns and good common hens I already had a large number.

Having decided what kind to get, the next question was, Where can I get them? Five hundred fowls is not a large number for a poulterer to handle, but is so large that it would be dificult to secure that number of select breeding birds at moderate figures. Three methods suggested themselves to me: ז. To procure pure bred birds from reliable dealers and stock my yards at once. 2. 'l'o procure eggs from pure bred fowls and hatch them in an incubator and by the aid of common hens. 3. To buy a sufficient number of common hens-say four or five hundred—and cross the best of them with pure bred cockerels, thus gradually raising up a flock that would be especially adapted to my wants.

The first plan was out of the question on account of the expense. Ou corresponding with a large number of prominent dealers I found that I could not secure fair birds for less than $\$ 2.50$ each. This would make the flock cost $\$ 1,250-a$ sum greater than 'I cared to invest in hens at that stage of the experiment, though I now look upon a stock which is worth four times that figure as a really good investment.

'l'o the second plan there were equally strong objections. To procluce 500 pullets would require the incubation of, at least, 2,000 eggs, allowing for cockerels, infertile eggs, loss of chicks, and culls. Now, clealers in pure bred fowls asked from $\$ 1.5^{\circ}$ to $\$ 7.5^{\circ}$ per settling for eggs; $\$ 3.00$ was a usual price, but taking the lowest figure, $\$$ r.5o for I $_{3}$ eggs, they would have cost $\$ 23^{1}$ for eggs alone. The inculator and its attendant would have cost a considerable sum, and the only immediate return would have lyeen from the sale of young cockerels, which in such numbers would only have brought the price of dressed poultry. But the most 
serious objection was, that at that time, I knew nothing about incubators and therefore the risk was too great.

I was therefore compelled to fall back on the third plan which was to purchase common hens in open market, and build up my flock by degrees. The great advantage of this plan was that the risk was small, since I could at any time get as much, or more, for my stock than I paid for it, provided it was judiciouly selected in the first place, and well cared for afterwards. - I could, also, secure a few pens of choice pure bred fowls at no very great expense, and from these I could raise small flocks which would enable me, not only to improve my stock of laying hens, but to carry out my experiments of crossing, etc.* I therefore, resolved to buy a sufficienc number of fowls in open market, using in their selection all the skill and knowledge of which I was possessed, and taught by former experience, the great danger of introducing even a single diseased fowl into a large flock, I determined to subject every lot to a most rigorous quarantine before giving it the freedom of the place.

But, in this case, it was necessary to provide accommodations for the birds before they were bought. It was well enough to buy one rooster before I had a coop) to put him in, but it would not do to luy 500 , or even 100 liens, without first erecting proper houses and fencing in suitable yards. I estimated that I would need at least six large houses and yards for layers, aud eight small houses and pens for common lreeders, besides at least three or four pens for small flocks of such pure breeds as I might wish to keep for the sake of improving my stock. I intended to begin with White Leghorn and Light Brahma, and I felt very strongly inclined to give the S] pangled Hamburghs a trial. It also occurred to me that in my miscellaneous purchases I might find some special strain or variety that it would pay to preserve. 1 therefore set out to build one

\footnotetext{
* It is surprising that we do not see more flocks of fowls bred for special circumstances when we cunsirlel the ease $w^{1}{ }^{1}$, which a large flock can be raised in

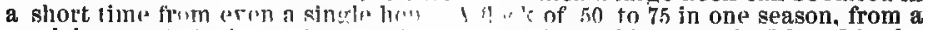

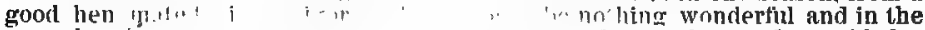
second $y$ (sit

(') 10 a thollsand provided a

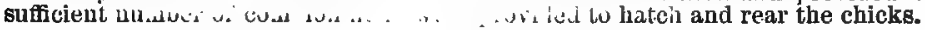


house and yard of each of these models and try it fully. I knew well enough that the first of July was in some respects a bad time to begin poultry keeping, but I also knew that I had mucls to learn, and that it was more easy to experiment during the warm days of summer and early fall, than during the frosts of winter. Indeed, I afterwards found that if $I$ had put off making a beginning until late in the fall, I would liave lost just a year.

Meantime our little broods kejt coming out and were gradually being dotted all over the grounds. The warm nights and pleasant days malle it easy to provide shelter for them, and they were so far apart that, at first, we lost very few chickens by their straying into other coops than their own. I felt greatly encouraged, for things went on swimmingly, but after a time I found that the business of rearing chickens is not altogether made up of successes. 


\section{fjous: Building.}

STy ORE than a quarter of a century before the time of which I write, I had built and used movable chicken houses, and was greatly prejudicen in their favor. At first, therefore, I. decided to have all my houses movable, so as to avoid any necessity for cleaning the floors. If makle movable, the ground on which they stood, might be cleaned by simply plowing it and planting crops. But, on working out my plans, I soon found that houses which would be readily portable, would be too small for my present purpose, and that if made large enough and movable at the same time; they could not be properly fixed up so as to resist the winter's cold without a great deal of trouble. Morever the glass leanto shed, upon which I set sọ much value, would be a very difficult thing to move without taking it all apart.

Of course I might have adopted houses built on a model which would allow me to take the entire house to pieces, move it to its new location, and put it together again. This, however, would take too much time and labor, so I decided to make my large houses stationary and with sufficient capacity to hold 75 to - roo fowls each. The houses and glass sheds were to have clay floors, :which I intencled to clean fiequently, and the yards were to be moved from front to rear, or from sille to side, as might be found desirable.

$\because$ For breeding pens I would need a smalier house-one that would accommodate comfortably seven fowls-six hens and a cock. For such a small flock, a large house, unless artificially warmed, is cold and cheerless, and to warm a house for seven birds would be a waste of fuel and labor. I theretore decidecl to make the breeding houses small and very warn, but this could be clone and still have them easily portable.

$\therefore$ In addition to pens for strictly breeding jurposes, I would theed 
occasionally a small pen for experiments, or to keep a cock by himself, or to keep two or three hens that I wished to test. . The ordinary breeding houses and yards would, however, answer all these purposes very well, and I determined not to multiply models and patterns if I could help it.

My first work, therefore, was to design suitable houses of these two kinds; and to construct one of each as a model. If this model worked well, then more could be made like it, and by making only one of each, I left myself an opportinity to introduce any improvement that experience might suggest. Fortunately, I hail as a study a very excellent model, though one that was rather too elaborate for the end that I now had in view.

Amongst other buildings erected by the former owner, was a poultry house of moderate dimensions, and no great cost, but the most perfect in its design and appointm snts' that I have ever seen, and I have examined some very costly ones. It was intended as a "family" poultry house, calculated for fifty hens and able to accommodate an additional one hundred young birds during the fall and winter, while they were waiting to be clrafied into the fattening coops. Mr. Brown told me, that it was designed by a friend of his, an engineer of considerable talent and broad scientific knowledge, and lie placed in my hands the drawings, specifications and descriptions, so that I might fully understand its construction and the best method of managing it. It certainly differed ratically from all the poultry houses clescribed in the books (and I have quite a collection of works on the subject) and as the designer gave his reasons for everything he did, it was easily seen that in every.point it adapted itself to the nature of the fowls, and to the dictates of true science. I will, therefore, give a detailed description of it, and to make this more clear will add an engraving.

Just behind the barn and on the edge of the woorland there was a very pretty knoll the slope of which was quite steep, $r$ in 4, as our engineering friend put it. The slope faced directly south, and the house was built on the side of this knoll, the enclosure stretching along the wood. I'he house itself was 16 feet by 14, and contained roo lineal feet of roosting poles which gave an average 


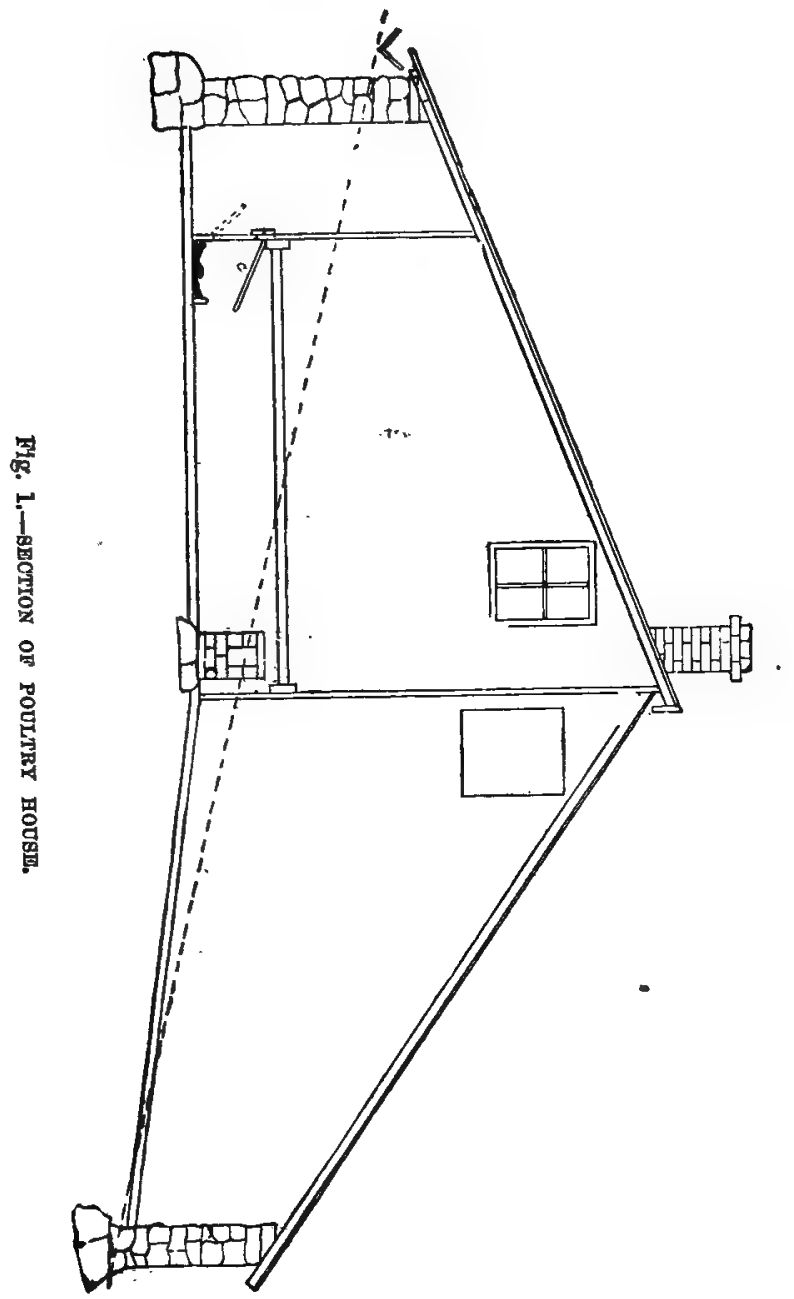


of about 8 inches each, to I 50 birds. In the engraving, Fig, $\mathbf{r}, \mathbf{I}$ have given a "section" of the house, that is to say, if the reader will suppose the house to be sawed across in the middle, it would present the appearance shown in the cut.

In the figure, the natural slope of the ground is indicated by the heavy dotted line. 'I'he back wall and also that on the nortl side are built of stone, of which there is an abundance on the place. 'The back wall was 5 feet ligh in stone, and the front wall of the house proper was of matched boards and 9 feet ligh. 'The roof also, as well as the south end were of matched boards. Parallel with the back wall, and $2 \mathrm{ft}$. 6 in. from it, ran a liglut partition extending to the roof, so as to provide an alley' way on this side. In this partition, however, was a long horizontal opening, closed by several doors or traps, 12 inch wide, and hinged as shown at $\mathbf{D}$. 'The oljegct of this was to allow of the inspection of the nests and the removal of the eggs without the necessity of going into the house. The nests were on the floor, and consisted of a good thick bed of the fine grass used for packing glass-ware. 'The front of the nests was a simple board 5 inches high and the nests were protected from defilement by the slanting board c. The roosts were rough poles cut to the same length as the width of the house, and flattened on two sides at each end. They were supporter by cleats nailed fast to the walls, two, cleats forming a wedge-shaped recess in which the poles rested firmly and securely. Nothing annoys fowls more than a rolling perch; a rocking one they can get along with, as when they roost on the branches of trees, but to a perch that rolls over they cannot cling with any confidence. 'The plan shown in Fig. 2 makes a fastening which is as firm as the wall itself, and yet all the roosts may be picked up in a few seconds and laid aside while the floor is cleaned.

The only glass used in constructing this house was the small window of four lights, shown in the end view, and this could be covered on wintry nights, so as to prevent the escape of heat from the building. The greatest mistake in poultry arcluitecture is the use of too much glass in the houses. We see houses with glass fronts, glass roofs, glass sides, and windows wherever there is 
a chance to get them in. Now, it is quite true that on . bright, sumsininy days such houses are very warm; incleed during bright sunshine the air in such a house will often rise to summer temperature while the thermometer outside is nearly down to zero. 'The glass acts as a "heat-trap"; the sulı's rays pass freely through, and warm up everything on which they fall, but the heat from the interior does not pass out through the glass so reaclily, as its intensity is greatly lowered. The cousequence is that more heat passes in than can pass out, and the whole house becomes warmed up. But, as soon as the sun's rays are cut off by clouds or night, there is no more heat passing in, while the out-going heat is as much as ever. 'The house then becomes rapidly cold, and the fowls will be frost-bitten in such houses when they would have escaped if kept in an old lean-to or even in a large cask. Therefore, if

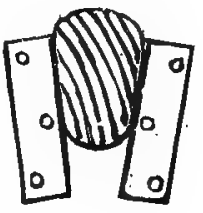

Fig. 2. we would keep our fowls warm during cold winter nights, without too great an expenditure of fuel, we must slun glass and keep them in houses with thick walls aind roof. 'This does not seem to be understood by the designers of poultry bouses, and even where a glass shed is merely attached to the house proper, they make the opening leacling from one to the other so large that the two might as well be in one.

'The designer of the house we are describing knew better. $\mathrm{He}$ made his house complete in itself and quite tight. Even the holes through which the fowls passed from the glass shed to the house were provicled with doors, which could be shut from the outside by means of a cord. In cold weather, there is no danger of not enough ventilation. A keyhole, on a cold winter night will admit air enough to fully supply the wants of three men, and the cracks in the best macle poultry house will always give air enough. As for the carrying off of foul exlalations from droppings, etc., the best plan is to neutralize all such by means of proper absorbents. Fully impressed with these facts, the clesigner made his house close and with walls prepared so as to be the best of non-conductors. Of course the stone walls always maintained a moderate 
temperature, and whereyer the walls consist $d$ of boards they were carefully lined with tar paper. This lining was applied by first nailing to the walls strips an inch thick. The pajer. was then tacked to the strips, and thus a dead air-space was enclosed between the wall and the paper. This, as every one knows, forms one of the very best of non-conductors, provided the air cloes not circulate in this space. To prevent this the strips were placed hori. zontally - not vertically, as is usually done, and thus all up and down currents were prevented.

But, in order that the full benefit of a glass house might be had for clear cold days, there was a glass shed, the same length as the house, but only twelve ftet wide, built against the south side. This was constructed in a very simple, but very efficient mauner, as follows: 'The wall on the east side was stone, about $3^{\circ}$ inches high, and after that of boards. The front was of stone, and the west sicle of boards. The rafters were narrow inch boards, tongued as if for matched stuff, and these were placed just so far aprart that the glass lay snugly between the tongues. The glass was then puttied in, beginining at the bottom, and allowing each light to over-lap the one below it. From such a roof snow slicles off as soon as a thaw comes, and. it is very cheap. Large ventilators, which could be ofpened or closed at pleasure, were placed in the east and west sides, as outlined in the figure, and in the front wall (that facing the south), there were openings whereby the fowls could go out and in, to the large enclosure; or to the open fields, when it was so desired. Directly over the front wall of the glass shed, and running the entire length of the house, was extended a wire netting which effectually prevented the fowls from getting on to the roof and yet was almost invisible, so that it did not detract from the appearance of the building. The outside of the south wall of the house proper, (chat which formed the north wall of the glass leanto) was painted a very dark reddish brown. This enabled it to absorb the heat of the sun's rays, whenever they fell on it, and this heat they imparted to the air, so that even on cold days the air in the shed. was quite warm so long as the ventilators were 
kept closed. When the ventilators were opened a very strong current was established at once.

In _such a house, without any further additions, hens would have lone well the whole year round, and with 100 birds on the roosts we doubt if one of them would ever have been frost-bitten. Under the glass shed our hens found dryness and warmth on bright days. A few barrowfulls of dry earth placed in one corner furnished one of the very best dustbaths-such a one as fowls do not ordinarily get during winter-and when dry warm days came, they could go out and enjoy themselves in the open air. But the designer was not satisfied with this, and therefore he provided means for 'procuring artificial heat during very cold weather. In this, as in everything else, he studied efficiency first, and economy afterwards, but in all cases the latter received due attention.

Warmth, during the cold months of fall, winter and early spring, is well known to be a most important point in the keeping of poultry for eggs, and the one most frequently neglected. Breeds, food and cleanliness are all essential, but without warmth they will be merely wasted. Much can be done by the construction of the houses in wh ch our poultry are kept, and if the house be small, the birils will keep each other warm, and little danger need be feared on the score of ventilation durng the cold seasons of the year. Much has been written on ventilation, and the general principles are perhaps sufficiently understood by most people, and yet, but few have any practical idea of the subject. Those who have not studied it experimentally have no idea of the great difference which a slight change of temperature makes in the ventilating power of an opening. On warm days, when the temperature outside is nearly the same as that of the inside, the air has scarcely any motion out or in, and we might leave small cracks or wide ones without any danger of "irafts." Under such circumstances, if we want to change the air in a house rapidly, we must open large windows, or even remove the whole side of the house, and so convert it into a shed.

But, in very cold weather, all this is changed. The inside of 
-

the house is then warmer than the outsille, from several causes. It may be that the walls and floor are giving off the heat they took in during warmer weather, or the birds themselves warm up the air, or heat is derived from some artificial source. In any case the greater the difference between the outside and inside temperatures, the more rapidly will the cold air try to get in and displace the warm air. Hence, the closeness with which this house was built, so that in winter these drafts might be stopped, while in summer, by opening the window and the large ventilator at the other end, and removing the straw or leaves from under the roof, a free current of air would be established.

In addition to the earth-heat derived from the bank in which the house was built, and the warmth of the fowls themselves, the heat required for cooking was utilized in the following manner: On the outside and near the front of the house was arranged $a+r_{5}$ gallon boiler or kettle. It was "set" in brick with a large grate beneath it, and the smoke and hot gases were carried through a horizontal brick flue which passed across the loonse along the front wall and about six inches from it, as seen in the engraving. The chimney was on the opposite side of the house, as shown. 'The brick setting of the boiler was enclosed with a small wooden porch provided with a door, and there were openings from this porch into the building, so that the heat miglst be allowed to pass in when desired. These openings could be tightly closed by shutters when this was thought best. In order to start the draft through such a long horizontal flue, the bottom of the boiler was lower than the floor of the house, the whole path from the porch to the front of the glass house being made lower also. In this way no difficulty was found in getting the flue to draw, especially as we always commenced the fire by burning a lot of brush, which gave a large flame and quickly heated the air all through the flue and chimney. There was also a flat piece of sheet.iron which we used as a blower. This brought the opening into the fire-place as low as possible. When the fire was once started the drauglit was excellent.

Now, as a horse, cow and several pigs were kept on the place, 
besides the fowls, it was found very advantageous to have a large kettle for cooking their food. In doing this the flue in the poultry house was thoroughly heated, and from the large amount of material it contained, this heat was not all gone until morning. A sheet iron pil:e would have cooled in ten minutes; this remained warm for as many hours, and since the cooking had to be done anyway, all the heat thus saved was so much clear gain. 'The food was cooked but once a day, the fire being started after dark. The animals then had a warm supper, (except the chickens, which had whole grain) and the kettle was again filled and allowed to stand till morning. Even after a cold winter's night the contents of a well covered 15 gallon kettle will be warm in the morning, and every animal on the place can have a warm breakfast.

It will be seen that the flue runs close to the front wall, and consequently crosses the jath of the chickens when they come in to roost. Two passages were therefore made through the brick work and under the flue so that they might go out and in at will.

The floor was a solid plate of aldobe, constructed by first spreading over the ground a thick layer of coarse gravel and broken stones, and then covering this with moistened clay which had been well worked. The clay was then beaten solid and forced down amongst the gravel and its upper surface was smoothed off. When dry it was so firm and hard that a blow from the heel of a coarse boot made no im ression on it. 'This floor was covered with dry eartl finely powdered Dry earth at once absorbs the droppings of the fowls, and prevents their becoming a nuisance. Every day or two the surface is well raked over so as to mix the droppings with the dry soil, and a thin conting of the same fine earth is scattered over the surface. Fifteen minutes suffices for this operation, and when the accumulated earth and droppings are wanted for any of the crops, they can be easily removed and the whole house cleaned.

The entrance to the house wals by means of a door on the west side, opening directly out of the alley wily that ran along next the back wall, and just behind the nest boxes. This brought the roof rather low, perhaps, but we never found it inconvenient, and the 
lower the roof, the better for the hens in winter: The roosting place was reached by a passage from the alley way, and there was a small opening (about 2 feet square) through the wall, through which dry earth could be thrown in, and the soiled earth removed. This opening was of course provided with a substantial shutter.

The shed was entered by a separate door, which served, not only as an entrance for the attendants, but as a way through which clean and soiled earth might be passed.

Such were the construction and appointments of this model poultry house. I made a careful study of all its features and workings, and found in it the germ and suggestion of my future buildings.

My first efforts were directed towards simplifying and cheapening the structure. The house could not have been called an expensive one; indeed, when compared with many that I had seen, it was a cheap affair, but when multiplied by fifteen (thie numier that I expected to build), the cost was too much. And, besides, it was larger than I neerled. I expected to get rill each year of all my surplus stock before very cold weather set in, so that each house would have to winter only its complement of 75 hens. For this purpose 6o feet of perch or roosting poles would be ample, and this coukd easily be put into a space $8 \times 14$ feet-just alout half the size of the large house. Moreover I determined to do inway with the passage at the rear of the nests, and allow the latter to be entered directly from the outside. If poultry was to be macle a business, somblyody would be on the grouncl all the time, anıl consequently there need be no fear of sneak thieves.

I therefore designed my houses $8 \times \mathrm{i}_{4}$ feet on the ground, and quite low-partly to save lumber and partly to economize heat. After making careful working drawings of all the parts, I sent to the mill and procured the necessary lumber, and my man and myself went to work. As we were both unskilled, to a certain extent, we adoptecl very simple, and what carpenters would probably call, absurd methods. Instead of making a frame, we sunk four posts in the ground, sawed them off to the right height, connected the 
tops with pieces of scantling and nailed pieces of the same scantling between them at the proper places. The rude frame thus constructed was covered with cheap matcherl lumber placed vertically, and the roof was formed of the same material and covered with tarred paper. There was one small window at the end, and the whole of the interior, except the door to the nests, was lined with tarred paper in the same way as the large house, and as the board cover to the nests fitted snugly to the walls, both along its edge and ends, the amount of cold that got in by this way was but small. The roosts and other arrangements were the same as in the large house. The figure on page 70 will give a clear idea of the construction of this poultry house, which, when finisled, was suug, strong and tight.

The front, which was 8 feet high, was placed facing the south, and against it was built a shed, but instead of a roof of glass, such as was used for the large house, I contented myself with two sashes such as are used for green-louses or hot-beds. The advantage of these was that no ventilators were needed-the sashes themselves serving for ventilators when the weather was warm. At the season at which the house was built, there was no need of this glass covered shed, except for rain, and for that a common board or brush shelter would have answered quite as well as one that was glass covered, but I wanted to test the working of a complete house before I went on to multiply them, and so I finished the entire structure-glass shed and all. Keeping poultry at certain seasons and under favorable conditions is mere fun. When the air is balmy and the fields are green, almost any shelter will answer for even the most tender little chicks, but when the storms of winter and early spring are upon us, and snow, sleet and frost cover the earth, then even the old birds find it hard work to maintain their existence. These difficulties I had fully experienced in former days, and I knew that while comfortable houses were a necessity, roomy sheds were no less essential. For this reason I had put a cheap roof over the manure pile, so that on wet and stormy days the hens might have a dry, warm place in which to 


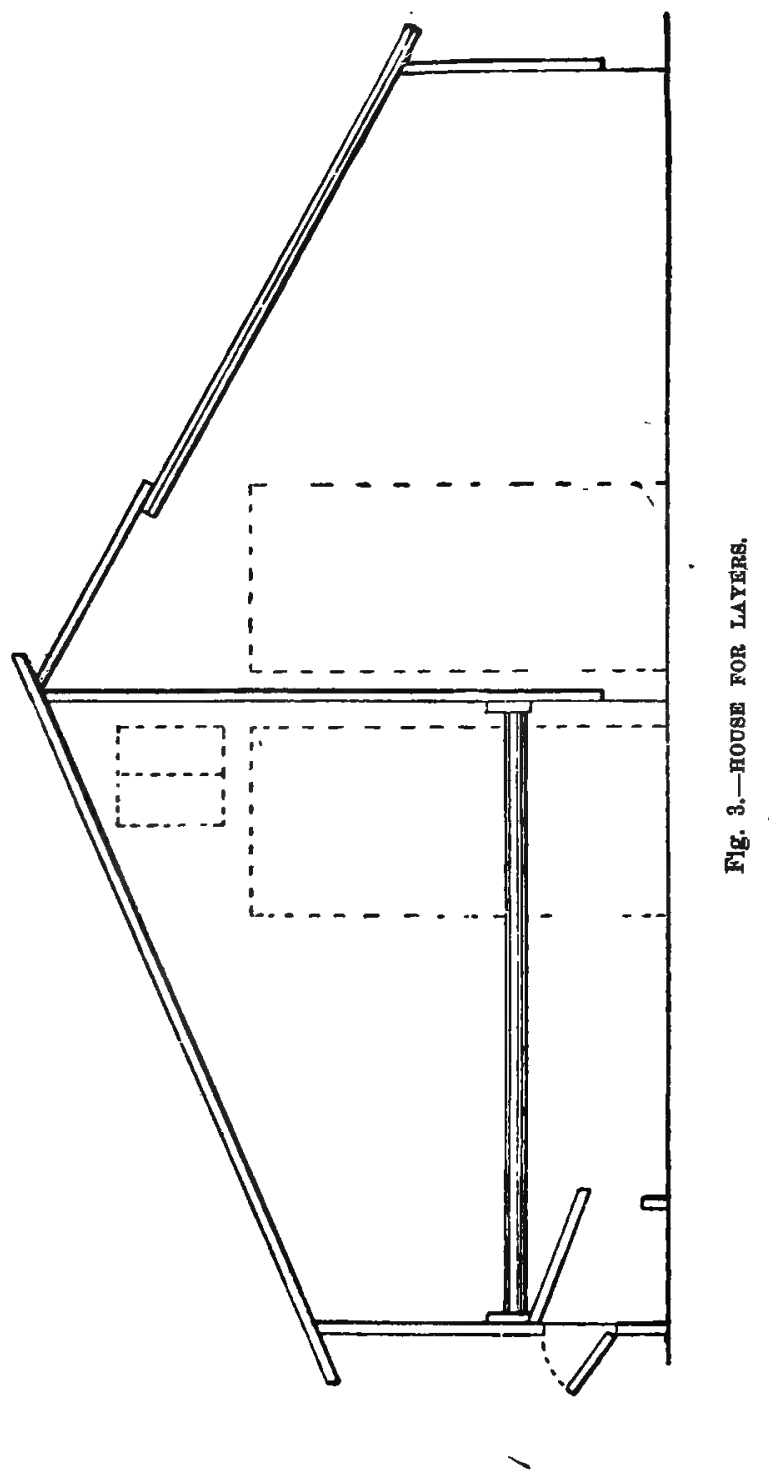


roll and scratch; but allhough this might serve very well for fifty hens, it was but a meagre allowance for five hundred, not to speak of a thousand, or, as I hoped to have at times, 3,000. I therefore saw that each yand must have its own shelter and its own sherls. The glass-covered shed served on very cold days for a clusting place, and a sort of warm room, but it was not large enough to accommodate 75 fowls. I therefore felt that a plain shed, open to the south, and enclosed on at least the rear and one side, would be almost a necessity, and so I put up one that was ro feet long and 8 feet wide. The height at the back was 2 feet and at the front 6 feet. During the summer, when the sun was nearly vertical, this afforded a nice cool shade at noonday; and in winter, when the sun was low, even at noontide, his rays lighted up every part and made it warm and dry. On wet days the hens used these sheds very freely, and so much comfort did they seem to take in them that I put up two for every house. These, with the glass shed, gave nearly four square feet of slıelter for every bird, and to this I attributed a large part of my success.

After the house was frinished, the next thing was to surround it with a proper fence, stock it with hens, and test its working. 'This I did, and I could find no point in which the house itself could be inproved without greatly increasing the cost. Of course I could not, at this season, test it for cold weather, but I had no misgiving on that point. I had successfully kept fowls during severe winters in worse houses than this.

The only point in regard to which I did not fully test it was in regard to the number it would hold. The market price of hens was rather higher than I thought they were worth. I therefore contented myself witl thirty birds, which I purchased in the market and transferred to this yard. After ten days I gave them their liberty, and although they roamed all over the place during the day, and mixed with the old stock freely, yet they always returned to their own yard at night, and I believe very few of them laid away. One or two hens stole nests in the shrubbery, and as there was no rooster amongst them the eggs proved worthless, so that 
the hens lost their labor and we lost the eggs; but the amount lost in this way was but small, and became gradually less. I was perfectly satisfied with the work thus far, and would have at' once turned my attention to the construction of breeding pens if my thoughts had not been directed to another branch of the business, as I will detail in the next chapter: 


\section{Broods Intreage and OTronble Begins.}

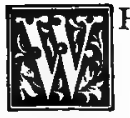

HEN, under ordinary conditions, a hen steals her nest and brings out a brood, the owner rarely has much trouble with the chickens. The mother cares for the eggs, generally hatches out a goodly proportion—often the entire lot-leads her young progeny along hedgerows and through coppices, and brings to the barnyard a fine lot of strong, heallily little birds. And even when the farmer's wife sets her dozen hens in different nooks and corners, and lets them wancler at will along the roadsides and through the orchard, there is rarely any trouble. The hens easily keep so far apart that there is no danger of their babies getting "mixed up," consequently there is seldom any danger of their fighting, or of chickens getting. killed by straying to the wrong coop. At first, therefore, we had no trouble to speak of. We lost some chickens from different causes, but this always happens; one got its leg broken by being caught in the cleft of a split board, and another had a fracture from a small stone which was loosened by the scratching of a hen and rolled down a bank. In both cases a good cure was made by simply wrapping the broken limb with a narrow strip of muslin which liad been smeared with very thick paste. The paste soon drierl, and held the bones firmly in position until they had united. In both cases the chickens became useful fowls. In another case, however, the little thing wandered off and was not seen until it was too late. The leg healed up, but the foot was turned the wrong way, and the poor little chicken found it difficult to walk, and impossible to scratch. But some one has said that everything-even evil-has its uses, and as an instance he names diseases, without which he claims that we could not have wise and learned physicians!* So this poor little

\footnotetext{
* To which some irreverent Phillistine has replied by asking, which, in this casie, was the good, and which the evil?
} 
lame chicken had its uses, for it taught us how implicitly the lower creatures will conficle in us if kindly cared for, especially when they are in a measure helpless. This helpless lame one had no fear of humanity; it would stand quietly and allow us to pick it up, expecting to be carried where fresh grass miglut be had, and as it ferl out of our hands and looked up in our faces it seemed to look upou us as its natural protectors. Some one luas said that to the dog, man appears as God, and, in truth, it may be so. 'To this lintle chicken we no doubt seemed an all-powerful Providence, from whose hands came food, and who provided shelter and protection. She grew to be a good-sized hen, and laid almost as well as those that were perfect in their limbs.

But when our broods multiplied, so that lawn as well as barnyard was dotted quite closely all over with them, then trouble began. The chickens woult run to the wrong coops and get quickly pecked to rleath; the hens would fight, and in their struggles the chickens would be scattered and sometimes seriously hurt. Another difficulty arose: Amongst so many coops the hens seemerl to lose the power of finding their own individual dwellings; two would try to get into one coop, and then fighting and destruction of the chickens would follow. By the time we had forty coops occupied we had our hands full, and more too.

I suppose that if the grounds had been of far greater extent, so that the coops could have been placed further apart, this difficulty wouk not have arisen. But to avoid it, the space occupied must have been enormous.

Now, it is well known that one of the great secrets in the rearing of strong, healthy chickens is the giving of freedom and all that it implies. Open air, grass to pick, leaves to scratch, dry earth to dust in, and ant-hills to explore-these are what go to make healthy chicks and vigorous fowls. But if the mothers fight and kill each others progeny when this freedom is allowed, what are we going to do?

The present broods had been hatched in all sorts of contrivances and make-shifts. Old barrels laid on their sides; boxes with and without bottons; old dog houses; a heap of broken straw laid in 
a corner, and half protected by a short board laid slanting against the wall; an old basket with a piece of sacking partially covering it; these, and such as these, had been utilized as the occasion arose. After we had used up such loose odrls and ends as came to hand, I bought a lot of cheap barrels, which had no heacls, and fixed them up as follows: A square hole was cut in the side, as shown in Figure 4, and the hoops were carefully fastened by means

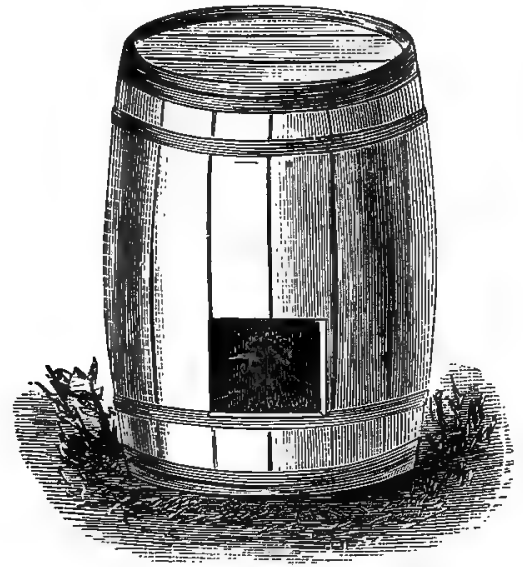

Fig. 4.

of a few wrought nails, which were neatly clinched, so that they might hold firmly and yet leave a smooth surface. The barrel was placed on the ground open end down, some fine grass or broken straw placed inside and moistened, ancl the eggs laid on this. A sitting lien was then put on the eggs, and the opening covered with an old sack. The hen would rarely return to this nest for the first few times, after she bad left it for food and water, but by placing her back once or twice she soon learned which was her own nest, and returned to it regularly.. The darkness seemed pleasant to her; the roomy barrel above gave her plenty of air, and, altogether, these nests were as good as any that we had for single nests. 
After the chickens were hatched we kept many of them in the old "tent" or triangular coops-a form which is, perhaps, one of the oldest and one of the best where there are not many broods: It has several advantages; it sheds rain perfectly, keeps the hen confined and allows the chicks to roam, and when the chicks return they can get away from the trampling of the loen by retreating under the corners. But it is a mistake to suppose-that the young chicks of several broods can be placed close together and allowed to roam about. 'They.will get into the wrong coops, and then wo beticle them unless the hens are very old and motherly. At any rate, our time was sadly broken up and our tempers sorely tried by hens that would not allow strangers in their coops, and after a few weeks' trial of this system the loss was so great that necessity compelled the invention ' of something different and more systematic.

I saw that a hatching room and brooding house would be a necessity, and I set out to plan and construct them. By the time I had fully realized the necessity for all this, however, and was prepared to go to work; most of our chicks were so large that they were past the most dangerous period. The dangers we have detailed are most fatal to chicks about a week old-just when they can run about freely and yet do not know enough to run away from danger. But as it was my intention to hatch considerable numbers of chickens in the near future, I concluded that I had better experiment a little and get my system into good-working. order, so as to be fully ready when the time of necessity came.

First, then, for hatching. Although it was the poorest time of the year for bringing out chickens (the end of July), yet I had several hens wanting to sit, and I thought I could afford to'risk a few eggs and chickens for the sake of Jearning by actual experience.

At first, I thought of building a small house specially for hatching purposes, but after thinking the matter over I decided to experiment in a room, or rather two rooms, that were in the barn, and so were ready to my hand. One of these I had already used as a temporary pen for a rooster and hens, the other opened into it, but 
had only a clay floor. The latter I deciled to use for a hatching room, while the other was to be used for a feeding room.

'The hatching room was $\mathbf{I} 2$ feet by $\mathbf{r}$. 'T'his gave 44 feet length of wall, and as I could have two rows of nests througly the midale, I estimated that I could have between fifty and sixty hens sitting in it at one time. Of course, in orcler to crowd this number into such a small room, it would be necessary to have nests made on purpose; old barrels, boxes and baskets would nerer answer. 'The nests might be made either fixed or movable, ancl the latter had many advantages. Fixed nests would soon get infested with vermin, and could not be cleaned except by clearing out the entire house, and this might not he always convenient. So I set to work to devise a simple, portable nesting box that would give each hen her own nest separate from all the others; from which she could not escape when once she was in; which could be easily cleanet, and which would give the birds plenty of air. 'This was how I did it.

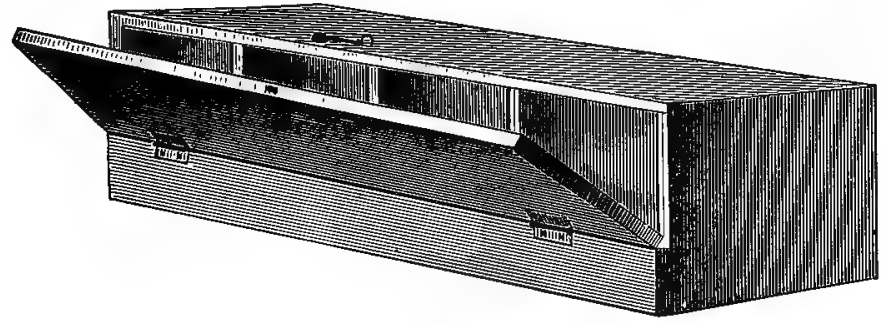

Fig. 5.

I made a box, or rather a crate (for it had no bottom or front), 4 feet long, 14 inches wide and 84 inches high. Fig. 5 shows a perspective view of this box with the door partially open, and Fig. 6 gives a section of one of the compartments. The top of the box is entirely.coveres?; there is no bottom, so that the nests rest on the ground; across the front, at the lower edge, is nailed a strip 4 inches wide, which not only serves to strengthen the: whole, but keeps the eggs and straw from falling out; along the lower edge 
of the back is nailed a strip 5 inches wide whicn answers the same purposes as that at the front, and in addition has the cloor linged to it. The door consists of a single board which is linged to the back strip, and when raised up may be hooked to the

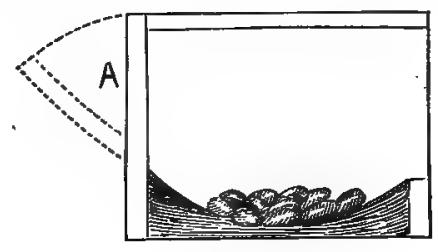

Fig. 6.

top. In very warm weather, instead of a hook, we use a loop of cord, which is so long, tluat, when slipped over the peg or nail in the top, it still allows the top of the door to stand out one or two inches from the edge of the top of the box. This allows plenty of ventilation, and to prevent the loop from slipping off the peg, thus allowing the door to fall down, we push a rough wooden wedge between the door and the top of the box, so as to keej the corl taut. There are four compartments in each box, each nearly 12 inches wide, and when such a nesting box is placed within two or three inches of a wall, the hens have plenty of air, and yet are securcly held as prisoners. Two boys can carry these boxes anywhere, so that they can be easily taken ont to be cleaned.

I macte sever of these boxes, holding twenty-eight hens. Along one side of the room I placed three, and along the middle I placed two rows of two each. The middle rows were placed back to backthat is, with the open sicles facing each other and aloout five inclies apart. Between them was placed a board 8 feet long and 14 inches wide, which completely concealed the birds from each other and yet left sufficient space for ventilation.

Every evening I looked over the laying nests and other places which the hens were most likely to adopt for nests for sitting, and marked such hens as were clecidedly broody. I had learned by experience not to trust a hen on her first attempt to sit, for some- 
times they will sit for one or two nights and then abandon the nest. But a hen that has occupied a nest for three consecutive niglts has probably made up her mind to incubsite, and may be depended upon. Such hens I transferred to one of the compartments in the hatching room, give her a setting of eggs and shut her in. Over the compartment was tacked a card on which was written the date, when set, the kind of eggs, ancl the datte when due. By pursuing this course, I very soon had every compartment filled with finthful sitters.

At first, I let all the doors down every morning and waited until the hens returned. Some of them delayed coming off for some time, others came off at once. The same diversity ap'peared amongst them in their habits of returning. At this time of the year a few minutes dicl not make much clifference to the ergss. With the thermometer at $80^{\circ}$ even one or two hours did not signify, but during Felsruary, wilh the thermometer down to zero, it would have lieen fatal to the unhatched chicks. It is true that the hens would probably return sooner in very cold weather, but prolsabilities would not ansiver my purpose. Could I control this matter completely without too much labor? I determinell to try. I therefore attended to this part of the work myself, so that I might learn all about it. The hens were regularly let off at seven o'clock in the mornung, and if any delayed to come off voluntarily they were lifterl off. All were driven into the outer room, so that they might feed and defecate. All who have hatd anything to do with sitting hens know what a horridly offensive smell is emitterl by the retained fæces of a sitting hen Therefore every precaution was taken to have this confined to the outer rooms, the floor of which was well coverel with dry sandy earth. A hoe stood conveniently in one.corner and at once enabled me to put an end to any nusiance. The ventilation was of course ample. Food and water stood in convenient troughs anil dishes, and the hens were never allowed to go outside. In this way no trouble in catcling them was ever experiencel. When they had been out half an hour, they were driven back to the hatching room, and allowed to return to their nests. Many of them did this without guidance or assistance, and this was so much trouble 
saved. Others tried to get into the wrong nest-one already- occupied by another hen; it was easy to notice this, pick up the wanderer and place lier in the first compartment that came to hand. Others seemed reluctant to go on; these we caught, placed them in a box and shut them up.

The success of this system was complete. The time required to attend to the hens was small; there was no danger of the hens going wrong when the attendant was absent; no danger of eggs getting chilled; no clanger of hens remaining too long on the nest without being fed. It is evident that it made no difference whether each hen returned to her own compartment or not; so long as each compartment had a hen, it was all that was wanted. It is true, that if the hens inad had different periods to sit, it would have mide some difference, but I saw that, in that case, I could readily classify them, say, into one, two and three week hens, and let each class out by itself. I was, therefore, perfectly satisfied with my system, and resolved to make preparations for carrying it out on a larger scale.

But when the chicks were hatched the work was only half done-perhaps not even that. 'The next thing was the care of the young chickens. Of course I wanterl a system which would work not only in fine summer weather, but during cold, damp days and with large numbers of chickens-not less than two hundred and fifty broods. Long before the chicks were due, therefore, I set to work to devise a system which would meet my needs, and as usual I turned to the books to see what others had done. I found plenty of coops for single hens and their broods; indeed, the inventive genius of poultry keepers seemed to have expended its whole energies in this department. 'The number of such coops that I found figured was simply astonishing, but as I had enough of my own, many of which had never been figured anywhere, I did not want them. I was surprised, however, to see that while nesting boxes and other arrangements for hatching chickens in large numbers received a great deal of attention, very little information was given in regard to their after-treatment in large numbers. I almost came to the conclusion that most of the "practical" men.had.got 
"stuck" at this point, and failed to carry their experiments any further. But this was just the point that interested me; I could readily hatch out chickens in any numbers, and, under my own system, with very little trouble, but when it came to rear them the problem underwent an entire change. The fact that I had had a pretty good training in the difficulties of the case encouraged me in the belief that I could achieve success. So far as the broods now in the hatching room were concerned, I did not feel uneasy, for by the time that they would be off, the older ones now on the lawn would have wandered off to the shrubbery, and I had enough single coops to take care of twenty-eight broods. It was the next season to which I looked forward with anxiety.

I saw, after very little consideration, that each brood must be kept by itself, and that for the first four to six weeks it must be confined to its own coop. I therefore set to work to devise such a coop.

The first question that presented itself was in regard to size. How much room does a hen and say twelve chickens require until the chickeus are, say, six weeks old?

On this point I could find very little information, and I had never kept chickens in such a bird cage before. I thought, however, that a coop 5 feet long, 15 inches wide, and ${ }_{3} 3$ inches deep, ought to bold them, and I adopted this as the size of my experimental coop. It was evident, however, that by using light lumber, not more than half an inch thick, five or six of these coops might be made in one block, and thus nearly half the lumber would be saved, while the whole coop would still be movable. I therefore procured a few half-inch boards of cheap stuff, to feet long and 6 and 7 inches wide. Two of these boards put together would make just the right depth-I 3 inches.

Having cut the boards in two I made a box, without bottom or top, to feet long, 5 feet wide, $\mathbf{I}_{3}$ inches deep, and divided into six equal parts by means of divisions running across it. Across one end, and 12 inches from the edge, was nailed a strip 3 inches wide. To this was hinged a board 12 inches wide and ro feet long, so that $\mathrm{I}_{5}$ inches of the rear ends of all the divisions were tightly 
covered. The a z-inch board could be lifted up so as to expose all the divisions. The other part of the top of the coop was covered with wire netting of one-inch mesh. The part under the board cover had a bottom or floor of light wood, and the passage between the net-covered and the board-covered portions could be closed by a sliding door. For the purpose of feeding, etc., there was also a hinged door 8 inches wide at the opposite end from the brooding apartment. By raising this up food could be introduced in saucers or other vessels.

This simple coop could be easily moved to any part of the grounds. If empty it was simply picked.up and carried off. If there were broods in it they were first driven into that part which had botli top and bottom and closed in by means of the sliding doors. The entire coop, hens, broods and all, might then be calrried to any place. Thus we set them down on the grass and they could pick to their heart's content. When they had soiled this spot we moved them to another, and towards evening we washed the grass thoroughly with water, for which purpose I had a simple watering cart made. It consisted merely of a barrel mounted on wheels and furnished with a short piece of hose.

I was surprised at the ease with which we cared for broods and raised them with the aid of these coops. My man said that it was as easy to take care of twelve broods in these coops as to care for one in the ordinary way.

We kept food constautly before them, but varied it at least four times a day, so that they did not become clisgusted with its constant presence. As they could not get out to pick tup worms and insects, we took good care to see that they had plenty of meat and cruslied bones. For drink they had chiefly buttermilk. Our cow was in full flow of milk and we chuined twice a week. We also bought all the buttermilk that one of our neighbors could.spare, and I never saw anything make chickens grow like this feed. In the morning they had bran mixerl to a stiff dough with buttermilk; at Io A. M. they had chopped meat-waste scraps from the butcher; at 2 P. M. they had ordinary "feed," and corn meal made into a dough with water; at 6 P. M. they had cracked corn. Buttermilk 
they had before them all the time. I never saw chickens thrive better than ours did under this treatment.

For feeding I bought a lot of chipped saucers at the crockery store for a cent apiece. 'These chipped pieces are unsaleable, and quantities are thrown away by every large importing house. By offering to take all they had for a month I got them at a very cheap rate.

I made but two of these coops before trying them, and by the. time I lhad fairly tested the system the other broods were so far advanced that they did not neel them. I kept them in the common tent coops and similar contrivances, fed them well, and they throve apace. My motto was that every chicken I could raise brouglit me nearer to the fulfilment of my ambition-the possession of $I, 000$ laying hens. The twenty-eight broods averaged nine chickens each when they were one week old. I divided them into broods of about fourteen each, and the ease with which this could be done in my new coops, showed me that the advantages more than balanced the cost. 


\section{preparing for a Btart.}

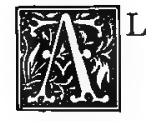

LL this preliminary work had merely been for the purpose of educating myself in the best mode of managing and handling chickens in flocks which might be multiplied to any extent. I was perfectly satisfied with my house, hatching nests and brooding coops; it only remained to arrange the places for the houses, put them up, procure the hens and go to work.

First of all, then, about the location of the houses. If I had studied neatness and order, I would probably have placed them in a symmetrical row, so that they might look as if some person of "refined taste" had had the ordering of them, and many a scolding I got from my wife for the hap-hazard way in which I- scattered them over the ground. But to have arranged them in a row would have rendered impossible one of the main objects I wished to attain, viz., the possession by the fowls of a sense of ownership of a distinct home. By placing a house in a corner by itself, putting a fence around it and confining its quota of fowls to this yard for a few weeks, I felt that I coulcl easily "domicile" each flock by itself. After this, so great was my faith in the desire of the fowls to keep to one roosting place, and in their power to find their way back to it, no matter how far they might stray, that I had no hesitation in allowing them their freedom over the entire place. Of course it was necessary to prevent their trespassing on the property of others, and in orcler to insure this, I proposed to fence in those portions of the grounds that were not naturally protected. Thus, on the north the ground was left open, because there was nothing but barren rocks above me on that sicle. On the east there was a piece of woods in which they could do no possible damage, but rather good by destroying insects. The owner was an absentee, and the land lay in commons, so I had no hesitation about letting the hens go there occasionally, as it was impossible for them to do any actual damage. 
But on the south side I had my very agreeable neighbor, with whom Brown had had so many quarrels. As I have alreacly stated, his land along my line was unimproved woods, lelt just as it came from the hand of Mother Nature, and it would have been impossible for the hens to do any harm there. Knowing my man, however, I erected a fence along the whole of the division line and a little beyond, so as to prevent any possibility of the hens "turning the corner." As I was anxious to have this fence perfectly cecure against even my best fliers, I used wire netting three feet wide, placed on a tight fence 2 feet high and surmounted by a single wire ratised ro inches above the wire net. 'I'bis excluded everytling. The little chickens could not get through the tight fence, and the wire on top' very effectually prevented the hens from flying over. 'They always aimed for the top of the wire netting, and striking against the sirigle wire, which was almost invisible, they fell back into their own grounds, and arose wiser if not happier fowls.

On the west there was a public roasl, and I have never known our hens to cross it, especially as our own orchard and garden lay between their houses and the land on the other side. While the garden crops were growing, the garden was fenced in with portable fence, which was removed in the fall, so that the birds might pick up the waste. In the orchard they were always supposed to do a great deal more good than harn.

It was very obvious that by giving each bird the range of the entire place it had a freedom and a chance for exercise which it could not have in a small yard. A thousand fowls on four acres, each bird having the entire range of the whole place, are far less crowded than $25^{\circ}$ birds on one acre, and these again are less crowcled than ten birds would be on $\mathrm{r}-25$ th of an acre, just as a man confined to a single house is more of a prisoner than any one of a million of men confined in a large city, about whose streets he can wander at his pleasure, his "range" being bouncled by miles. But if this city were divide(l up into squares—one for each inhabitant-and every man was confined to his own square, the prison. life thus forced upon the people would be unendurable. If my present stock of poultry were divided off into small lots, each lot in a pen- 
by itself, I am satisfied that the number of fowls now on my place would completely destroy all the grass and "vegetilbles" thereon in a very short time if they were kept constautly on it. Not that they would eat it, or even scratch it up, but they would trample it down, and their droppings would so defile it as to breed disease and ruin. But my hens spend three-fourths of their time under the feeding sheds and in the dust baths, and in bright dry weather they improvise dust baths for themselves all along the northern aind eastern line, where the land is light and the aspect sunny. And all along the line the buslies are so planted, or, when the bushes were there already, so thinned out as to form little sumny nooks ancl alcoves, as it were, where they are completely sheltered from wind and always find a dry dusting spot. At first, I found the tendency very strong to scratch up the ground and make a great hole just at the trunk of the young trees, thus injuring them very seriously. 'T'his I soon stopped by laying a few good sized.flat stones on the ground around the trees. I also trimmed up the evergreens on (he south and east sides, so that the sun could get under their branches and dry the ground and the fallen pine needles. This was no doulst a barbarouis proceeding in the eyes of all tandscape gardeners, but the hens enjoyed it.

'The grass land is heavy, and they go there only to feed on the grass and insects, but their eagerness for green food led them on to the grass land so often, that I found it necessary to provide other food, and to keap it in good condition. 'This point gave me a great deal of trouble. The problem was to keep a plot of green food of some kind constantly fresh and attractive to from $\mathrm{I}, 100$ to 3,000 fowls-allowing them to "pasture" it at will. After carefully studying the different plants with which I had had experience, I could think of but two that would answer my purpose-Rye and Clover. Clover was my favorite, but it was difficult to keep' a supply all the time; rye made a good preparation for the land for clover, and at the same time furnished green food during early spring, and even during the winter when the weather was open. The trouble with rye was, however, that it did not seem to stand the tramping, etc., of the birds. It is true, that I could fence them 
out at times and feed them with cabbage, and I did so with good results. In winter $\mathrm{I}$ use clover hay cut very fine in a hay cutter, steamed and mixerl with meal of corn ancl oats, ground together. I have been told that I cannot grow clover many years, however; that in time my land will get "clover sick"-whatever that may mean-and the plants will die off. Perhaps this is so, but as I see no signs of such a calamity at present, I shall not trouble myself. "Sufficient for the day is the evil thereof," and when my land refuses to grow clover, I will try something else. I am now experimenting with the Southern Cow Pea and with Prickly Comfrey, and I think that if necessary I may possibly be able to do without clover, but as yet it is the best plant I have found-requires the least labor in proportion to the amount of valuable green food obtained.

I therefore set out to provide a plot of very rich green food for my hens, and I laid off a strip 200 feet long and 75 feet wide along the edige of the paddock, to which $\llbracket$ have already alluded. This I proposed to plow up in the fall, manure heavily and sow to winter rye. The following spring it would be top-dressed and sowed to clover, so that after the rye was gone, its place would be supplied by another plant. 'This plot of land I intended to fence in, and $I$ also intended to run two dividing lines of movable fence across it, so that I could feed it off in strips of about 48 feet wide. 'Thus, after the plants had got a fair start, the fowls would be admitted to a strip at one end, 48 feet wide. As soon as this strip showed signs of giving out, the fence would be movef, the hens exclusled from the 48 feet on which they had been feeding, and another 48 feet would be given them. I chose 4.8 feet because this was the lengtl of three fence panels each 16 feet long.

I found that it took three weeks for the hens to clear off such a plot, and that by the time the rest of the plot had been gone over, the grass and clover had become taller than was necessary. W We sometimes had to mow it and give it to the cattle. Whenever a good rain came shortly after the foyls were shut off a plot, the growth was very rapid, and we took the hint; and if a dry 
time ensued, we sprinkled it heavily with water, which was by no means a laborious operation.

I now arranged the location of the houses; one was already up; and I made arrangements for putting up seven more immediately; so that I might procure my fowls. In arranging the location of the houses, however, I found that it was difficult to supply thein' with water, and experience had taught me that good water is one of the most important things in the care of all kinds of live stock. 'Tlie only water on the place was the well, and the spring from which a stream flowed directly into "Nabal's" grounds. I worried a gobde deal over this, and had almost determined to sink another well and procure a wind-mill, when, by a singular episode; I was relieved. from all trouble on this score. 


\section{An Epiqode.}

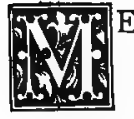

EANWHILE the season was gliding past, and the first days of August were fully upon us. Everything looked well, the crops were good, the animals in good health, and we were all enjoying country life, or would have clone so, had it not been that my wife's health failecl, and she showed strong symptoms of a malarial attack. At this I was rather surprised, for the atmosplere was so clear, the water so pure, and everything appparently so conducive to health, that when our family physician told me that it was a veritable attack of marsh fever, my heart sank within me, and I said to myself, "Is it possible that no region is free from that scourge of our country?" The hired girl, ton, sliowed symptoms of an attack; she was a strong, fresh-looking girl when she came to us, but she had fallen away wonderfully both in health and looks, and now showed constant signs of weariness, against which she bravely fought in vain. My own health.cohtinued unaffected, but then I believed myself to be ague-proof.

I was sorely puzzled over this new development. The land all round us was pure and wholesome, and yet I was convinced that some unseen marsh must be the source of our illness. The Browns had never been troubled in this way, but then the present season had been unusually hot and dry, so that ponds which in other years had been filled with clear, wholesome water, were now stagnant and putrid. But none of these ponds lay near us, and so the problem remained unsolved.

One day, however, when passing along the lower part of my grounds, I heard some ducks quacking and making that peculiar noise which ducks do when they stick their bills in mud. Like a flash it struck me that here was the cause of all our troubles, and in an instant $I$ was on the other sicle of the fence on an exploring expedition. I saw enough to con ince me that there would be no 
health at Ferniebield until that little marsh of a quarter of an acre or so had been drained, and I also saw coming towards me witli hurried step the irate proprietor.

"What do you want here?" he asked in his loudest and most churlish tones. "Don't you know you are trespassing ?"

"I want to see you," I replied very quietly. "I see that the hot weather has reduced this pond to a marsh, and it has given chills and fever to my wife and servant, and endangers the health of my chilclren, and I have come to ask you to drain it."

"Get off my premises. I want none of your sneaking here.. I dont propose to drain my ponds for you or any man."

"Pardon me," said I, "I will go if you wish me to do so, but if I go away under present conditions I may return in a way that you will not like. If you object to drain the marsh, for it is not a pond, yourself, will you allow me to do it at my own expense?"

The answer was too rough and savage to repeat, and I left him, but not until I hacl used my eyes to good advantage.

Now, the origin of this pond and marsh, as I afterwards learned, was as follows: The land which was now the source of malaria had in former years been quite dry, and was underlaid with a deep bed of clay. But on the grounds of Ferniebield, gushing from the bosom of the mountain, there was the beautiful spring which $I$ lave already mentioned, and which yielded as much water as would fill a two-inch pipe. The spring was almost unvarying in its flow. Wells might go dry and streams shrink, but this little spring always seemed to be full. Not many years back, however, it had flowed across Ferniebield in a diagonal direction, and the old water-course was still visible throughout its entire length. But a violent. "thuncler spate" lind sent a torrent down the hillside-a flood the like of which no inhabitant could remember-and this flood had passed over the spring, and opened for it and for itself a new and wider channel, through which the waters of the rivulet had ever, after flowed. Formerly they had flowed past "Nabal's" property ; now they flowed directly into it, and he had taken advantage of this fact and constructed costly ponds and fountains, which . were sup: plied by this new accession to his property. Now, if he had been 
a wise man, knowing that the spring arose on my land, he would have met me more than half way, but being a churl he was likewise a fool.

I had three plans open to me whereby the nuisance could be abated. I. I could apply to the Board of Health; they would very quickly rectify matters if they did their duty. 2. I could commence a civil suit for lamages, and procure an order from the court to abate the nuisance. 3. I çould abate it myself at once by turning off the water. I chose the latter course, partly because it was the speediest. A good sprade in the luands of a stalwart man generally goes straight to the point, and knows nothing of the "law's delays." First of all, however, I consulted a lawyer of great experience and sound knowledge in regard to my rights in the case. I was informed that I had a perfect right to restore the water to its original course, and, moreover, that inasmuch as it arose wholly on my land, I had a right to do what I chose witl it.

I at once employed three good stout laborers, and we went to work and cleared out the old channel most effectually. It had been entirely filled in in some places; these we dug out and reopened. Amongst the property which Brown left with me, but which I did not purchase, merely held awaiting his order, was one of Gurley's Architectural Levels. 'This almirable little instrument enabled me to make sure of my course, and I found that when the water passed off my land the bed of the stream would be so low that there would be no possibility of bringing it back to Nabal's property except by means of a force pump. So we worked away, and in forty-eight hours I had the old channel cleaned out, and the present one very effectually filled up. As the sparkling stream dashed over the pebbles and rushed into its old bed I could not help thinking of my little friend Nettie and her murdered pets. I knew that thousands of dollars had been spent on the ponds and fountains of our unneighborly neighbor, and that these were now all useless. The fountains were now nothing but dead lumps of iron and dead blocks of stone, and the pond, instead of being "a thing of beauty," would be a noisome, stagnant pool, sickening. and disgusting its owner, until in self-defence he would be obliged 
to drain it. Truly, Nettie was well avenged, and I did not feel sorry.

But I knew that for a week or two, things would get worse instead of better, so I sent my wife ancl childien off to al distant relative, and gave the girl a vacation, telling her to stay away until I sent for hẻr.

It was not long before our friend missed the water, and rushed up to my door in a perfect rage. He wanted to know how I had clared to change the natural course of a running stream, and threatened all sorts of vengeance. I quielly ordered him off the premises, telling him that the spring was mine, and I coulk do with it what I pleased. He refused to go, telling me that I coutl not put him off. Of course he meant pliysically, which was quite trute, but there were others on the premises that could. It was to me a matter of no consequence how long lue staid; lie could not undo what I had done, aud I felt satisfied. So I simply slut the door in his face aud walked into the house. I knew that if he did any damage he could be made to pay for it.

After a few minutes he walked away, and next day I received a letter from his Jawyer, notifying me that if I did not restore the stream to what he called its proper channel, he was instructed to begin suit at once. As his adviser had the reputation of being a very able lawyer and a perfect gentleman, I thought it luest to call on him and explain. He was eviclently a. litlle surprised when I gave him the facts in the case, though, with a lawyer's caution and slurewdness, he would not acknowledge tlat his client had marle a mistake. Next day I received another letter, asking me to call if convenienit. I made it convenient. The lawyer explained to me the great expeuse to which his client had gone to fit up his place, the beauty of which was greatly marred by my action. He stated that his client had directed him to institute a suit for damages, lut wisling to avoid trouble he wanted to know if I would not restore the water to' its former channel, provided guarantees were given that no nuisance should be allowed. I positively refused. I tolk him that I wanted the water for my own use, and that I rould not trust his client under any circumstances. In due time I was served wifli' 
the papers in the suit, and also a notice to show cause why I should not be "enjo ned" from diverting the stream, as they put it, but I noticed that the attorney in the case was not the one with whom I had had an interview. He had evidently aclvised his client not to enter the suit. It cost me a small retainer to my lawy er, who put in an appearance for me, but the case was abandoned and I never heard any more of it.

One most gratifying circumstince through all this fight was the sympathy and gord feeling extencled towards me by all the neighbors. "These rude dwellers on the hillsides had little sympathy with any man that "put on airs," and when it went so far as to make his neiglıbors sick, they were "down" on him, as they expresserl it. 'I'lis little episolle brought me into closer connection with the people around me than anything else could have done.

'The stream now flows through my neighbor's ponds and fountains, but "Nabal" is not my neighibor. "Nabal" was so deeply chagrined over bis defeat, that he took matters greatly to lieart. He who had lorded it so over all the hillside was now beaten. But worse than that; securities which he considered as sound as United States notes went from above par down to the tens. He solk out, and the loss so curtailed his income that he could not maintain his country-seat. $\mathrm{He}$ disposed of the property at a great sacrifice, and another now occupies his place. That other is a "Nabal" only in one particular; he has a most excellent wife.

When I gave Nettie an account of all this she was greatly pleased, although she felt very sorry for "Abigail."

We divide the water between us; there is enough for both when properly managed. And so it came to pass that a never-failing stream of clear, pure water flows past my coops and through my yards, and this I regard as one of the most important of the many items which go to form the elements of my success. 


\section{Wards and fentes.}

Fif $Y$ first thought was that fences, except for the breeding. pens, would be an unnecessary expense, seeing that the birds were to be allowed the range of the entire grounds during the greater part of the season. I soon found, however, that I coukl not dispense with a well-fenced yard around each house, as it would be necessary at times to confine the birds to their own domicile for various purposes. 'The most important of these was the training of the hens, so that each might know its own roosting place. I had found, in former years, that when a few hens and a cock were confined for some weeks in a breeding pen, and became accustomed to roost in there, it was almost. impossible:to change them, except by a repetition of the same process. On one occasion we had aloout twenty hens whose roosting place we wished to change. For several weeks we carried them nightly from the old to the new house, and at the end of that time fully two-thirds of them returned to the old place. I then shit them up, day and night, in their new quarters, for about three weeks, and we had no more trouble. Now, every season we would have 500 young pullets to accustom to a new roosting place. They would be divided into lots, each lot would be placed in its own house and yard; and fed there and compelled to roost there, and I knew that they would almost all come back after they were given their liberty. In this way, and this only, could I obtain the benefits of the system which I had adopted.

But, in addition to this, there were various other occasions on which a well-fenced yard would be of great advantage. 'Thus, every fall the young cockerels would have to be separated and placerl by themselves, and various other necessities would arise. Movable fencing was therefore a necessity, or at least a great convenience. 
The permanent fence round the yard already on the place was made of what are called" "shingling laths," the pickets being 9 feet long (an 18 foot lath cut in two). These laths are $\mathbf{I}$ inch by $\mathbf{I} / 2$, and may be obtained of certain lengths-12, I4, 16, I 8 feet, etc.

Of portable fencing there were various kinds described in the books, but the choice lay between the simple lath fence I had used years ago and a fence of wire netting. The great objection to the latter, however, was its cost. It is very neat, almost invisible, and for small runs auswers admirably. But it costs $1 \mathrm{~T} / 2$ cents per square foot, which on a running foot 7 feet high, as is necessary for most of the non-sitters, amounts to roI $/ 2$ cents per runuing foot. The r6-foot panels which I used cost about half that sum per foot, or less than at dollar each, and the labor of putting up the lath fence is greatly less than that required for the wire netting. I had two kinds of lath panels; one for fences where there were birds only on one side, and the other for division fences where bircls were on both sides.

The engraving, Fig 7 , shows the style and construction of an ordinary panel. There were three horizontal rails, consisting of shingle laths, each sixteen feet long. These laths being $\mathrm{r} \times \mathrm{I} \mathrm{T} / 2$ inches, were placed with their edge towards the upright plastering laths. This gave a greater depth of wood for the lath nails to sink into, and also grealer strength against the bending of the fence sideways by wind or the pressure of birds flying or running against them. The wind, however, does not seem to take much hold of such a fence, although they act as valuable shelters. The two lower rails were connected by a diagonal brace which was firmly nailed to to each rail at the end. The diagonal was simply an 18 foot shingling lath, cut to the right length and the proper shape at the ends.

The end slats were also made of shingling lath-a 16 foot lath cut in two. They were laid flat against the horizontal rails, and nailed firmly with wrought nails, which were clinched. As the length of an ordinary lath is 4 feet, and as the ends of the laths lapped past each other on the middle bar only a very little, the fence lacked only an inch or so of being 8 feet high. The upper laths were 


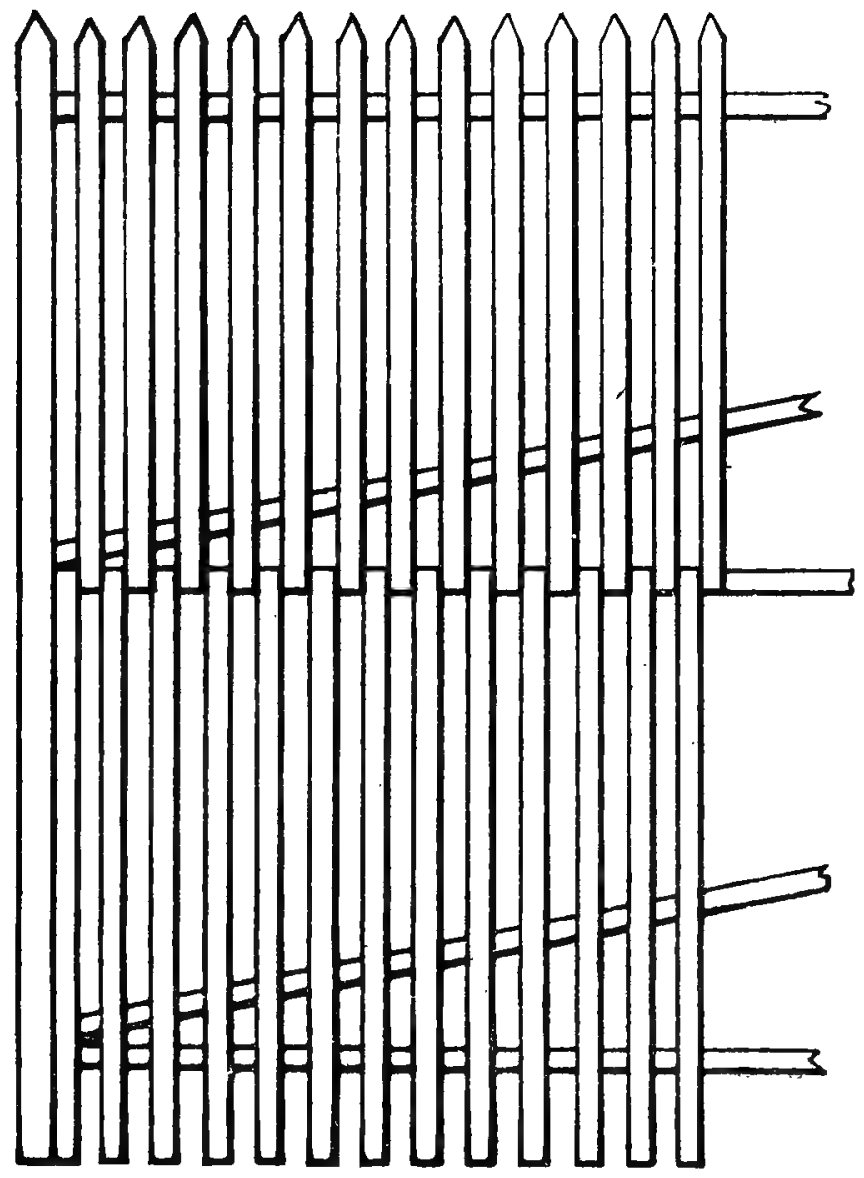

Fig. 7.-POBTABLE LATH FenOE- 
pointed, so as to prevent any bird that might fly on to them from resting there. None of our birds, however, have ever got over these fences, as we are in the habit of trimming the quills of the wings of our Leghorns and Hamburghs.

When my man made the first few panels, he pointed the lower laths also, and placed their tops several inches above the middle rail. 'This formed one of the best traps for chickens that I ever' saw. 'I'hey would jump up, their heads would slip into the wedgeshaped opening between the laths, and there they would hang by the neck. I lost several fine hens in this way, until I had the tops of the lower laths sawerl oft square.

At first we had some trouble, owing to the tendency of some of the lath to split. We soon remedied this difficulty, however, by wetting the lath. When thoroughly wet they are not easily split.

'The lath were pointed by means of a draw-knife and a carpenter's wooden vise. A small circular saw would no doubt have done the work better.

After the panels were completed, they were placed against some straight fence or wall to dry, which they did very rapilly. They were then painted with crucle petroleum, and panels so treated have been in use five years without showing any sign of deterioration.

Such panels are very strong. I have heard complaints of lath fences being weak and liable to be broken down by the birds, in which case, of course, mischief would result. In my own yards no breakage has ever occurred. I have no doubt but that if a cow or a horse ivere to attempt to pass this fence they could succeed, but that any bird short of an ostrich could break it down I do not believe. I have seen heavy birds-birds weighing twelve poundsthrow themselves against this fence in their fights without proclucing any bad effect on it, and even good-sized dogs have rushed against these fences without injuring them. It will be seen that the lower rail is abont a foot from the bottom, so that the shock given by dogs and birds comes at the strongest part of the fence, and the diagonal brace is also a great help against any local blows. I have therefore come to the conclusion that lath fences that break down easily must either be badly constructed or made of very 
poor materials. A great point is to flace the rails flat, so that $a$ good size nail may be driven wholly into solid wood.

With a supply of panels like this, and a proper number of stakes or posts, a yard can be put together in a very short time. The first thing, for those who are not used to the work, is to roughly lay out the yard, marking the corners with small stakes or markers. If there is to be a gate, the place where it should come ought to be marked, and the house ought to be in position before the yard is laid out. My houses had strong "screw eyes" at the corners where the fence joined them, and to these the outside picket of the first panel of fence was tied either with strong cord or with wire.* The panel was then held in position, and a hole made with a crowbar just at the place where the post should be set. The post or stake is then driven into the ground to a depth depending upon the character of the soil. This work is clone by means of a wooclen mallet or maul with a long handle. We made the mallet ourselves out of a piece of a tree, using an old hoe handle for a handle, With such a mallet a man or stout boy can drive a stake 3 inches in diameter into the ground so deeply that no common animal can push it over. The untied end of the first panel is then jlaced against one side of this post, and the end of another panel against the other side; and both are tied to the stake either with tarred cord or soft wire. The second panel is then placed so that it and the first panel form a straight piece of fencing, and the point where the second post should come is markel with a crowbar or "hole opener," as we call it. This hole opener is of peculiar shilpe. It consists of a long bar of iron or steel, with a pear-shaped ball at the lower end, as shown in Figure 8 . Such a crowbar, if pointed with tempered steel, can be driven two feet into hard ground with great rapiclity and ease, while a common crowbar would require hard and protracted. labor. The heavy point is first driver in, and the bar rocked a little in two or three directions. It is then raised and again driven into the hole with as much force as possible, and again rocket. This operation is repeated until the

\footnotetext{
* The wire that comes off baled hay answers very well for this purpose, and may be had for almost nothing from those that use this kind of hay.
} 
hole is deep enough, and it is surprising how rapidly the work can be done. We always started the holes in this way, but in soft spots it is best to drive the stakes wholly with the mallet.

After a little practice it becomes unnecessary to mark off the boundaries of the yarls. The eye becomes a good enough guicle for the direction, and the panels being all i 6 feet, the size can be told at a glance.

When there is to be il gate, the gate is treated like a panel, except that the tie which serves for the gate does not tie the panel next it. 'T'he gates were made just like short panels, but there was a diagonal brace above as well as below. The gates were quite light, easily lifted and moved, so that no hinges were used. The tie was made of several turns of wire, instead of two, as used for the panels, and one of those three-cent wire hooks and eyes, of good size, was used for a fastening. This was not as convenient as a proper hinge, but it anirered every purpose for the breeding pens. The gates for the large stationary yards were, however, made more subsiantially. The gate posts were nicely squared, and the gates had a special picket for receiving the hinge. This picket was made of so-called inch boards (nearly 7-8ths thick), 3 inches wide, ausl carefully selected Fig. 8. for soundness and strength. Loose butt hinges were used, and as the post was held upright by the panel on the other side there was no sagging, and the gate always worked smoothly.

There was another form of panel used for division fences. In division fences, that is, fences between two yards, it is necessary to have the lower part close, so as to prevent fighting. This was done by nailing half a lath between every one of the lower row of latis. These laths dicl not quite fill up the space, but the openings were so narrow that $m$ lighting could occur. The balf laths were firmly mailed to the lower rail, and a line of selected lath was run horizontally alsout 2 inches below the top of the half laths. These horizontal laths were mailed to the half laths, and also to the others, with small - wrought nails that clinched. 'These division panels 
were surprisingly strong. We doubt if any animal; short of a horse or a cow, could have broken - them.

'l'he panels were ensily and rapidly made by using proper facili. ties. Four posts were sunk in the ground, so as to make the legs of a sort of bench r 6 feet long, 8 feet wide, and the usual height of a workbench. Along the front a good plank i 8 feet long was laid. It was braced in the middle by nailing it to the edge of another plink 14 feet long. Of course the latter plank was on the under sicle, and, as it presented its zeidth against any force tending to bend the upper plank, the bench was pretty stiff. 'Two pieces of plank, each 8 feet long, were laid across the end posts, so that the bench was a sort of skeleton affair closed on three sides, the other side being open, and the midlle also quite free. Six feet from one end of the bench two other posts of the same height were set, and across the top was laid a plank 8 feet long. This was intended to support the panel when it was shoved off the large bench when nailing on the top row of lath. Having the material all handy and prepared, the three rails were laid down, their ends resting on the end planks of the bench. The two stout end pickets were then nailed to them, the proper position of the rails being shown by a rod, properly marked. All the panels were, therefore, precisely the same. 'This framework of the panel being now held square, the diagonal brace was cut to fit accurately, and then firmly nailed in its place. Then the first lath was nailed on, a thin board, 6 inches long and $\mathrm{I} / 2$ inches wide, and having a block nailed to its upper surface to serve as a handle, being laid between it and the first picket so as to get the space right. The rail into which the nails were being driven rested on the long jlank, and all the laths were nailed at one end before an attempt was made to nail the other. 'Then the middle rail was laisl on the plank and the other ends of the lath nailed to it. 'Then the diagonal brace was laid on this plank and the lath nailed half way up. The panel was then turned round, and standing between the top and the middle rail the upper half of the diagonal was nailed.

Everything was now finished except the nailing of the lath to the upper half. The panel was strong enough to resist much bend- 
ing when laid flat and supported in the middle, but to avoid any bending I had put up the support previously described. The workman now stood between the top and middle rails with the end of the panel resting on the end plank of the bench. The first top lath was nailed at both ends and the panel shoved along. As a matter of fact, however, the plank was $\mathbf{2}$ inches wide, so that three lath could be nailed before moving the panel. This process was carried on until the space between the last picket and the lath became too small to admit the workman, when he stepped out and nailed the last half dozen lath without difficulty.

I have been astonished to see how quickly an expert workman can nail up a panel. I had one workman whose labor on the panels did not exceed 18 cents each, and yet he was earning fair wages.

It is also surprising to see how rapidly those who are accustomed to this kind of work can move one of the breeding yards and houses to another spot. The process is as follows:

Catching the hens: To do this they are all driven into the house, gently but quickly, through the ordinary hole that adimits them. An empty crate is then placed with its open door against this hole and the hens are easily driven into the crate, which is closed and allowed to stand where it is until wanted. The wires or cords fastening the panels to the house on either side are cut. It does not pay to spend time untying them. A sharp knife for the cord, or a pair of cutting pliers (found in every hardware store) for the wire does the business instantly. 'Two men then pick up the house by the handles and walk off with it to the new location. As the house has no bottom or floor except the ground, the old nests and all the dirt are left behind. The house is then properly located, and to those who have done the job before, that is all the marking off that is needed.

The panels are then all cut loose and laid across two poles, each about ten feet long and lying on the ground about 34 inches apart. These poles serve for a hand-barrow, and the panels must be laid so as to balance. As soon as a load is laid on, two men pick them up, using the ends of the poles for handles, and carry them 
to the new place. When there are four men at work, it is better to place the poles further apart (say 6 feet) and lay on twice the load. There is then one man to each end of the poles.

The posts or: stakes are then drawn out of their holes by means of a lever and chain. A lever, $\mathbf{2}$ to $\mathbf{5}$ feet long, is used, and a small chain or stout rope fastens it to the post. Of course the lever is horizontal, and is supported at the short end by a block of wood, so as to prevent it from sinking into the earth. A lift on the long end brings the post up so far that it is generally quite loose, and can be drawn out by liand.

All this is done with a rapidity that would astonish those who are not accustomed to such work. The process of putting the fence up again has been already described.

My first undertaking, therefore, was to construct a sufficient number of fence pavels to enclose yards for seven houses for layers, and ten breeding pens. I saw that this could not be done in time by working at it "at odd spells," so I hired a carpenter and two assistants and set them at work on the houses and fences. 


\section{Breeding pens.}

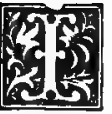

HAVE already descrilsed the simple pen in which I placed the Brown Leghorn cock and seven hens. It answered its purpose admitably, but having but one box of the kincl there used, I could not make any more like it. Nor, indeed, do I think I would have clone so, if I had had them, as I felt sure that I could improve upon it. Again, therefore, I ransacked the poultry books, and general works on architecture. I even found books specially devoted to this branch of building (it scarcely deserves the name of architecture) and I studied them, but after all I found nothing that seemed to meet my presents wants so well as the small movable houses I had used a quarter of century before. They were made of matched boards, and entirely without flooring. They were 4 feet 6 inches long by 3 feet 6 inches wide. The front was 5 feet 6 inches and the back 4 feet high. There was a door 20 inches wide and 4 feet high at one end, and a small window consisting of a single pane of glass $8 \times 12$ at the other. The latter might be covered during cold nights with a shutter, which was attached just below the window by small hinges, so that during the day time it could be turned down and at night it could be turned up, so as to cover the window, when it was held in place by a small button.

There was a hole in the front, through which the birds entered, and this hole could be covered by a board placed on the inside and sliding over the opening.

There were two roosts, made of young trees, each 3 inches in diameter and 3 feet 6 inches long. They were placed so as to divide the ground space equally. This gave 84 inches of roostsufficient for ten fowls of the largest size. The roosts were movable and when it was deemed desirable to enter the house, they could be lifted out without trouble. At the same time they were 
perfectly firm, being held in V-shaped spaces between cleats-the same as those used in the large house.

The nests, or rather nest boxes, were a part of the house. In the figure is shown a section of the house, where it will be seen that the nests form a row along the back, being covered with a slanting board. 'The nests are simply a little fine marsh hay laid on the ground. The hay and eggs are kejt in place by a 4 inch board which russ along the front of the nests. Each nest is a compartment by itself, divided off from the one on each side of it by a board which reaches up to the under surface of the slanting board. Indeed, the latter rests on the tops of these division boards. The nests are accessible from the outside, so that the poultry keeper need never enter the house. 'The way to get at them is to let down the board which runs across the eutire back of the house, and is hinged to the stationary board below it. Both the side door and the door giving admission to the nests are provided with hasps, so that they may be locked by meaus of one of those cheap cast iron padlocks known as "jaul locks." Such a contrivance is proof against nneak thieves. A burglar would break the whole house up in half a minute, so there is no use in putting on strong and costly locks.

- Along the front is a row of pickets, to prevent the birds from flying over. The pickets are 16 inches long, being simply laths cut into three parts.

On each corner there are handles consisting of pieces of boards shaved into such a shape as to be easily grasped by the hand. They are firmly secured to the front and back by means of wrought nails, clinched. Four stout boys have no difficulty in picking up one of these houses and moving it wherever it is wanted. Indeed, two men can do it.

The inside of the house-sides, ends and roof-are lined with tarred paper, nailed to cleats one inch thick, which are fastened to the house as detailed in our description of the large house. This makes the house very warm, and the matched boards make it perfectly rain proof. To protect it from the weather it was coated 


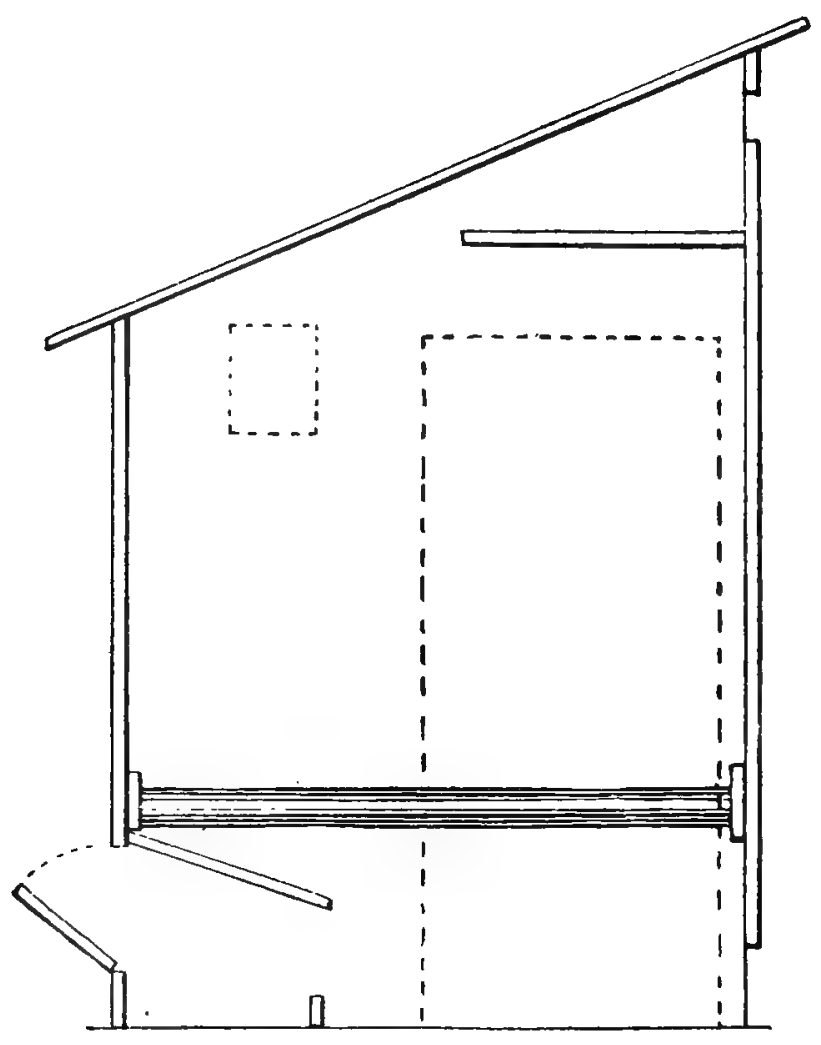

Fig. 9.-HOUSE FOR BREEDING STOCR. 
with crude petroleum laid on like paint. Of all the preservatives that we have ever tried, this is the cheapest aud best.*

Another important point-ventilation-was not forgotten. In cold winter weather, very little ventilation is needed, and I depended largely upon the cracks round the door and other openings to supply it. But cracks and openings are bad things, and to have left a crack at the bottom, and made a hole at the top, would luave passed such a current of cold air over the fowls as might have produced frozen combs and wattles. To avoid this, three holes-2 inches in diameter-were made aloug the front-that is at the highest part of the house. Under these holes was placed a thin board shelf, 14 inches wide, and during cold weather the space between the shelf and the roof is packed with straw. Tlis, of course, puts a complete stop to all currents, but every chemist knows that through such porous packing the foul air will pass off by a process of "diffusion," and pure air will enter from the outside even agaiust a considerable current. Moreover, the straw acts like the "regenerator" in Ericsson's first caloric engine, and absorbs the heat from the outgoing air to give it up to the incoming.

I have described the house, as. we finally made it. . Before committing myself to a particular pattern I marle one myself, and having surrounded it with a yard of portable fencing, I put seven hens and a cock into it and tried it for a couple of weeks. I foumd a few points to modify in my first model, but the final outcome was as $I$ have descrilsed and was very satisfactory.

* Crude petroleum may be obtained at a very cheap rate by the barrel, and is easily applied. If too thick and sticky it may be thinned with benzine or gasoline. When using it, great care must be taken not to allow a light to come near it, or the whole house would be in a blaze. We painted our houses ontside and in before we lined them with tarred paper, and one of them got pretty badly scorched, by a workman, who struck a match near one to light hie pipe. It was a windy day and he stuck his head in to get shelter for the match. It was the only time any one struck a match near these houses, as he got badly burned, the petrolein having been thinned with gasoline. After a few days the volatile matter passes off, and the petroleum sinks into the wood, rendering it hard, durable and very difficult to set on fire. Crude petroleum is death to insects. It will be a long time before houses painted with this material will bo infested with lice. 


\section{Ataking a Gtart.}

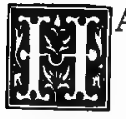

AVING completed my plans for houses, pens and fences, and made one of each, so as to test its working and convenience, I set to work to construct a sufficient number of yards to hold 500 birds, together with those, old and young, already on the place and coming forward. I intended to send all the old fowls and culls to market, as som as it would be advisable to do so, and after some inquiry and a comparison of old market reports, I believed that the best time to sell would be the spring. Thus, I found that during the preceding fall what are known as "fowls" sold for $12 \mathrm{I} / 2$ cents per lb., while in the spring they lad brought 20 cents. On a hen 6 lbs. weight, this allowed 45 cents for her keep during the winter, and as many of the hens, if properly cared for, would lay during, at least, part of the time, it was evident that spring was the most judicious time to sell. As I proposed to buy about 500 hens, and as I had about 60 on hand and expected to have 300 or 400 young pullets out of the broods now on the place, I calculated that I would need, at least, eight houses, and about ten breeding pens, in addition to those now on hand. So I made my calculations, ordered the lumber, and kept the carpenter and his assistant at work.

I was anxious to take advantage of the market at once, and to procule my hens before cold weather came, so that I might not only have them in good health when I got them, but be able to get them into good condition to withstand the winter. I also wished to quarantine every lot that I purchased in market; that is to say, I wanted to keep it by itself for a few days before letting it run witli the others. While the breeding pens were under way, therefore, $I$ interrupted the work and had a large shed put up. It was 40 feet long and about 16 feet wide, and was constructed in a .very simple manner. Stout posts were sunk at the four corners, 
and lighter posts between at distances of 8 feet. The back row was only 3 feet high, and the front row 8 feet, and rails of scantling were nailed along the top and also near the bottom at the back and ends. To this scantling rough boards were nailed vertically, and narrow strips were tacked over the joints. The roof consisted of boards $x 8$ feet long, with the joints covered in the same way. These boards were supported in the middle by a suitably arranged beam, so as to bear the weight of any ordinary snowfall, as I intended to leave this shed up all winter. Eight roosting poles ran from end to end, being placed as near the back as possible, and all on the same level, so that there might be no fighting for the highest place. About half an acre of grass land was enclosed around it by means of the movable fence. When a lot of fowls were purchased, they were first placed in one of the breeding yards, or in two yards if the number was large. If no disease showed itself in a week they were transferred to the large yard around the shed, and kept there until the houses were faished. If disease had shown itself, I was prepared to "stamp" it out by well-known methods-the slaughter. of the birds and the disinfection of the house and yardsbut fortunately $\mathrm{I}$ had no occasion to resort to any suclı measures

I was now ready to go into market and buy my hens. For several days I visited the dealers' stands without seeing anything that suited me, but at last perseverance was rewarded, and I found two crates containing some very nice common hens-compact bodies, bright eyes, red combs, and with feathers hard and clean. There were twenty-two birds in one crate and seventeen in the other, but several of them were cocks. I tried to buy the hens only, but found that at wholesale prices I had to take the entire lot or none. I therefore bought them all and sent them to my yards. They weighed 159 lbs., or a little over four pounds each. The cocks (of which there were thirteen) were separated and placed in a pen by themselves, while the hens of each crate were kept separate and placed in pens. I tried to sell the cocks by the crate, but found that the loss was considerable. Birds which cost me fifteen cents per pound would only bring twelve cents when I tried to re-sell them. As I did not want this first lot anyway, 
however, I sold them for what they would bring, and let them go. But even on this basis I found that it paid better to buy the entire crate than to ask the dealer to let me pick.

Next day I found a crate of beautiful White Leghorns. There were seren pullets and nine cocks They brought no more than the most common stock, and I bought them all. 'The dealer said that he had no doubt that if he harl marked them up, and offered them as breeding stock, he could have secured a far higher price for them, but then the expense and trouble of keeping them in the narrow quarters of a city store would have more than offset the increased price. His rule was, therefore, to sell all such stock at regular market prices and at the earliest possible moment. I founcl out afterwards that they came from a party whose strain of Leghorns was really good. The birds were very fine, and I concluded that the cockerels were good enough for my breeding pens. I also found another crate of large bircls of somewhat mixed blood, bat very handsome, and apparently very healthy. In this crate, strange to say, there were no cocks, so that I regarded the purchase as a very happy one.

On talking with the dealers, I found that the crates were filled in various ways. Sometimes a farmer or country gentleman, wishing to lessen his stock, would fill a crate with fowls and send them in. Most generally these lots were the culls of the yarl, and presented a somy appearance, but occasionally, where the owner had fine blood in his stock, the crates were filled with pure brecl, handsome birds. Crates of the latter kind were rare, but I managed to secure two such crates of Dominiques, one of Light Brahmals, and one of Brown Leghorns, lsesiłes the crate of White Leghorns already mentioned. Other crates were filled by lucksters, who bought up fowls from farmers and others, put then together in lots of fifteen to twenty-five, ancl oflered them for sale on the streets. Buying such crates was a good deal of a lotiery; frequently two or three very good birds would he found mixed with a lot of the veriest trash, and sometimes a country henwife would have a lot of sick chickens, and they would find their way into these lots, the owner being anxious to sell them and get the money before the birds 
died or wasted away. I generally gave such crates the go-by, biut on one or two occasions I made some fine additions to my yards.

I pursued thịs course until I had secured 537 hens and about 3 oo cocks. The birds, as purchased, were carefully looked over, and all that seemed to be in the slightest degree out of health were placed in quarantine in one of the yards, and kept there until I was certain that all was right. I was very fortunate, however, and did not lose a single bird.

The mongrel cocks were placed at once in large coops and liberally fed-soft food forming a large part of their diet. Two weeks of such treatment made a great improvement in most of them, but on some of them it had no effect whatever. They were killed, dressed and sent to market as tast as they could be got ready; and brought fair prices, but I loubt if the results paid for the time, feed and labor expended. If I were to stock another yard in the same way I would send the cocks to market at once and get rid of them, charging the loss to the cost of the hens.

$I$ was now realy to take stock. I found that I had 537 hens, which cost me to date $\$ 302.23$ for birds, food, etc. This allowed for the money received for the cocks sold, but I had on hand a small quantity of food (perhaps $\$ r_{5}$ worth) the cost of which is included in the $\$ 302.23$, and which I have not taken into consideration.

The hens were a motley lot. When a number of hems of even pure-bred fowls of different varieties are mixed together, they are apt to have a mongrel look, while even a lot of real mongrels, provicled they are all nearly alike in size, shape and color, may present a very attractive appearance. My first work, therefure, was to sort them into lots that were tolerably well mated.

Out of all the cocks, I saved only a few White Leghorns, a Spangled Hamburgh and three Dominiques. I was satisfied that they were sufficiently pure and good to enable me to experiment with them. Meanwhile, I obtained from different noted breeders, one Dark Brahma, one White Leghorn, one Spangled Hamburgh; and three Light Brahma cocks, and I set aside the ten small coops to accommodate them, and two White Leghorns, one Spaingled 
Hamburgh and one Brown Leghom, from my general purchases. 'Then, beginning with the Dominicques, I picked out all the best hens that I could find of this breed, and when I got through, I found that I had three very respectable breedling pens of this variety. Indeed, I confess, I was somewhat surprised to find them so good, and as the cocks were all first class, I looked forward to having come excellent results.

I then took the pens containing the Syangled Hamburgh cocks. I did not find a single hen to match, so I filled each of them up with four of the best Dominiques $I$ had le!t and two very fair Brahma pullets. In this case, too, $I$ had no reason to feel dissatisfied.

Next came the White Leghorns. There were quite a number of very excellent Leghorn hens amongst my purchases, so I filled one coop with the best I had. This was a very handsome pen. In the other pens I placed Dominiques and Braluma hens. I liad great faith in this cross and resolved to give it a fair trail.

With the Brown Leghorns, I did not have such good luck. I luad no Brown Leghorn hens that could be called pure, and my Dominiques were now getting down to culls. However, I made up two of the best pens I could, and awaited results.

The ten pens drafted sixty hens from my flock. With those I liad at first and what were left of the 537 hens I bought, I had just 523 left over. The problem now, was, to dispose of these bircls.

My experience has been that to change the roosting place of a hen is a difficult matter. A setting hen is a stubborn thing, but she is gentleness itself, compared with a hen thit is determined to roost where slue is not wanted. I have never been able to change the roosting place of a hen, except by slutting her up in her new coop for two or three weeks, and even this plan does not always work. Of course, when a hen is removed to such a distance that she loses all knowledge of her locality, she may be made to roost any: where. This was the condition in which my hens were at this time, so that all I had to do was to sort them into lots of alsout 75 eacl, place each lot in its own house and yard, and leave them 
there for two or three weeks. At the end of that time they were to have the freedom of the entire place.

For the first lot, then, I carefully examined my flock and selected 75 birds, all as nearly alike as possible, and as near like Dominiques as I could get them. We now tried to transfer them to their own coop, but in so doing some serious accidents occurred-one fowl had a leg broken, and another had a wing dislocated before we had captured a dozen. I acted as looker on, while younger and more active legs and hands did the work of catching. The young men that. I employed were not rough or thoughtless in regard to the pain inflicterl upon animals, but I could see that to handle four or five hundred birds, catching them by hand, was a task that no one could perform without great risk of accident to the fowls. I therefore ordered the wounded birds killed and stopped all further proceedings. The men were set at work on the next house, while I went to town to procure a good net. In my younger days I had had considerable experience catching fish with a landing net, and I felt that with a good instrument of that kind I could catch any fowl in my flock, without ruffling a feather or hurting a limb. So before I went I told the carpenter to get me out a pole of the lightest but straightest grained pine he could find, 7 feet long, I I $/ 2$ inches in diameter at the butt and $1 / 1 / 8$ inches at the top. When I returned I brougint a bag net, 30 inches in diameter at the moutl, but very considerably less at the bottom, and 40 inches deep. I also had a tough, dry hoop pole which was passed through the upper meshes of the net and then tied firmly to the pine pole. It was, in fact, a huge landing net with $\mathrm{I} / 4$ inch meshes, and I proceeded to try it. Selecting a bird, I walked gently up to it, and by a surlden movement, I placed the net over it and had it. If I hacl used a $b a g$, the bird would have dorged under the hoop but as the net seemed to offer no obstruction, the bird ran right into it, and was caught. It was no trouble at all, and thereafter I needed no help) in catching the fowls. But I found that after they were caught it took too much time to carry each bird singly to its new yard. I therefore had a transier coop 
madt. It was simply a light but strong frame work, two feet high, rour feet long and three feet wide.

'The bottom was closely slatted, and the sides and top were macle of lath cut in two and nailed on. 'In the top was a door which lifterl up and through which the fowls were dropped. 'This door' was close to one side, and when we wished to give the birds their freelom the coop was placed on its side, the door opened, and the birds allowed to run out. I could easily put twenty lens into it, and two men could then carry it to any part of the grounds. I soon filled it, carried it into the new yard, and gave the birds their liberty without a single accident.

By this time, however, the hens had become pretty wild and somewhat difficult to approach. I therefore arranged some portable fence, so as to make at one corner of the large yard a small enclosure somewhat of the form shown in Fig. Io.

At the corner, $a$, the two fences ran quite dose to each other; at $b$ the space was much wider; at $c$ the outside fence and the portable fence came together again, and another length of fence stretched from $c$ to $d$, so as to make a wide throat to the enclosture. It was easy to drive any particular fowl into $d$, and when once there it could be driven through $c$, where a boy stood with a pole and kept those that were in from coming

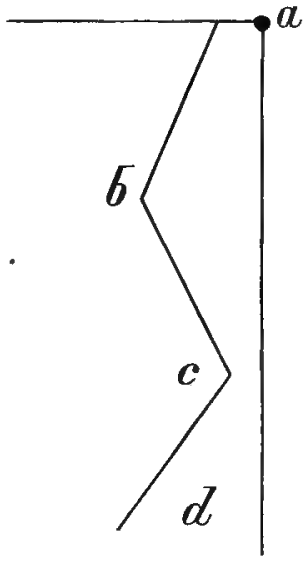

Fig. 10. out. If some got in that were not wanted it was no matter, as they need not be caught. When enough were in it was easy to close the passage at $c$, and by means of the net select the birds that were wanted. It is possible that other poulterers have better methods of catching birds than this, but I have not seen any. Where there is but a small number of fowls togetler it is an easy matter to catch any one at night on the roost, and I have done this :very often. But where 75 hens are to be selected and cauglut out of 500 , and 
carried to a new coop, the hand net saves a great deal of trouble to the owner, and many a twisted leg and wing to the birds.

The first yard made quite a respectable appearance after all. Although I had found it difficult to complete my third breeding pen of Dominiques, yet when I had got together all the hens that resembled Dominiques they formed a very handsome flock, fheir very numbers seeming to cover and excuse any slight irregularity.

The second yard I filled with birds that were as nearly white as possible. Amongst them were quite a number of pure Leghorns and some very light Bralımas. Most of them, however, were evidently mere mongrels. After I had sorted out 75 white birds of pretty good quality I had nearly 30 white ones left, but many of them were quite inferior.

Those for the thild yard were selected to match, as nearly as possible, a hen which was in the lot that I found on the place, and which my little friend Nettie used to call Dame Parten. She resembled somewhat a Brown Leghorn, and was a most excellent hen, though rather small. She laid a good-sized egg and plenty of them, and she herself we had placed in a lreeding coop with a Brown Leghorn cock, but we adopted her as a model for yarl No. 3 , and we succeeded in getting over 60 hens that nearly resembled her. Rather than break the uniformity of the yard, I let it go with this number.

It now began to be difficult to find enough birds that would match in color to fill any one pen, so I adopted a somewhat different plan. I now matched them for size and shape.

The hens that were originally on the place were of all shapes, sizes and colors, but as they knew the old coop, and the old coop only, as their home, it was not best to try and make a change. I therefore let them remain as they were, merely adding enough birds to make up roo-a number which I considered it possible to accommodate comfortably. 'The hens that I selected were the best of odd colors. Some of them were very handsome birds, but the lack of uniformity told greatly against their appearance.

In making up the other yards I now began with the poorest. I picked out all the smallest and least promising of the birds that 
were left and put them together. The remainder were then simply divided amongst the other yards according to size.

Towards the last I found it necessary to use the movable fencing used for the large yard. I therefore finished all the houses and put a yard roind one of them. All the fowls not already provided for were transferred to this, and then the large yard was dismantled, the fence taken down, nests, etc. consigned to the manure heap, and the fence posts pulled up. With this material at hiust it was easy to enclose the other yards in a few hours, so that the birds were not kept very long in confined quarters.

The birds seemed to take kindly to their new homes, ancl as the entire place was new to them all, at the end of four days I let one lot out and gave them the freedom of the place. Every one returned to its own house-perhaps because they could not go anywhere else. Next day I let another lot out. After four days I let two lots out together, and as soon as all the lots had been out I opened all the gates and gave them all their freedom. When this had been done and the birds, on a fine day, were scattered over the place, I was considerably surprised at the small show that they made. The place looked as if it could hold ten times as many with great ease. This seems to be always the feeling when a thousand or less birds are seen together. The flock does not appear as large as we expected. 


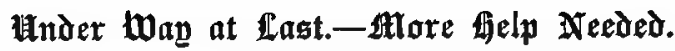

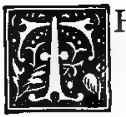

HE enterprise was now fully under way. More than half the laying stock was on hand; a goodly number of young chickens were coming forward for next year, and I felt that twelve months from the time of which I write I would have my poultry farm in full working order, and that the question of success or failure would have been decided. Already we began to get some returns in the shape of eggs, although, of course, the number was small-about six dozen per day from all our hens. Still this was quite as much as I expected, for experience has taught me that hens which have been worried and frightened, and probably kept on short allowance of food and water while passing from the liands of the seller to that of the purchaser, cannot be expected to lay for some time. Hence, I have always found that for the time being, other things being equal, bircs reared on a place are much more valuable for that place than those that are pnrchased. After a time, however, the birds pick up and begin to lay, and it is just possible that the stoppage caused by moving may throw the laying period into a later and more profitable season. This was my case precisely. The hens kept laying more and more as the season grew later and eggs grew dearer, and this was, of course, to my advantage.

I A great deal of nonsense lias been written about egg laying which it would be well if poultry breeders would get out of their heads. One of the most erroneous and yet most plausille theories is that advanced by Geyelin in his book "Poultry Breeding in a Commercial Point of View." He gravely tells us that "it has been ascertained that the ovarium of a fowl is composed of six hundred ovulas or eggs; therefore, a hen, during the whole of her life, cannot possibly lay more eggs than six luundred, which, in a natural course, are distributed over nine years in the following proportion: 
First year after birth......... I 5 to 20

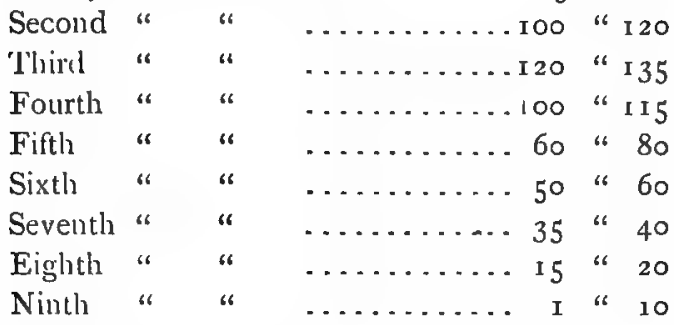

It follows that it would not be profitable to keep hens after their fouth year, as their produce would not pay for their keep, except when they are of a valuable or scarce breed."

'I'his theory is evidently a mere modification of that popularly held in regard to seeds. Many believe that the huge oak lies coiled in miniature in the acorn, and that the process of growth is a mere unfolding. It is needless to say that in the sense here expressed this is untrue. And so with the ovaries of the hen. Geyelin's theory is that even in the little chick the future eggs all exist in microscopic embryo, and are merely "unfolded" as the months roll by. No man, having a sound knowledge of physiology, could hold any such opinion. The same power which originated the most microscopic of the egy-embryos that we see in the ovaries of a laying heu, when we kill her and cut her open, exists with all its potency in every healthy hen; and may go on developing new eggs ad infinitum, provided other conditions do not interfere. These conclitions are the exluaustion produced by rapid egg-laying; the decay of all the powers by age; the accumulation of fat when the bird is highly fed, and its weakening when food is stinted; these and similar causes limit the number of eggs produced by any one hen, and not the fact that her store of embryo eggs is exhausted. Hence, the number of eggs laid by different hens varies very much; some are quickly exhausted by a small number, others go on laying freely, and it is for the poulterer to determine what the character of his flock shall be in this respect. 
The hens now in my yards were in pretty fair condition. Some of them were, evidently, quite old and slıowed no signs of moulting; some of the younger ones were already beginning to moult. I took care that every morning they all had a liberal feed of rich soft food, and instead of the number of eggs that were laid decreasing, they actually increased-an unusual thing for this season of the year. But this involved extra work and care, and $I$ soon saw that more help was needed to do the bircls justice.

In restricting the number of fowls the first year, I was guided, in a measure, by the amount of help at my disposal. My own time I considered equal to half that of one man; the servant girl renclered us some valuable assistance, and the man gave perhaps one-third of his time to the poultry. With this amount of labor at command, it was difficult to give more than ordinary care to the number of fowls on hand, together with a few broods, so that I felt the need of some person who would give his whole time to carrying out the details of the work, while I devoted myself to superintendence, marketing, etc. Having a stout man to do ally hard work or heavy lifting, it occurred to me that an honest, carefill woman would prove the best assistant, if I could find one willing to do the work.

I made quite an extended inquiry, and had a great many offers, but without any favorable results. The objections to those who applied were obvious and numerous, and I was about to give up) iu disgust the idea of employing a woman, when I received a visit from the pastor of a German Catholic cluurch, in a neigliboring city. It seems that he had heard of my want, and that amongst his parishioners was a woman of about forty-five, who had come to this country a few years ago, from Switzerland, with a husband and step-daughter. The husband had died and the daughter had got married, and the poor woman was alone in a strange land. In this country, those who are willing to work need rarely be idle, and she found enough to do at odd jolss to keep her fully employed, but she wished to find a home where employment would be permanent. On inquiry, I found that she had been accustomed to work out of doors, when she was in Europe; she was strong, healthy 
and had been accustomed to the care of animals. Her pastor recommended her very highly for honesty and steadiness, so I gave him what we thought would be her expenses in coming to see me, and arrunged a time when she should meet my man with the spring wagon. She came and after she had seen the coops, houses and yards, and had her duties fully explained, she thought that she would like to try the place at any rate. So I engaged her and set her to work at once, sending my man that afternoon for her truuk, etc.

Her duties were to be the care of the fowls of which she was to have entire charge under my clirections. The man was to perform certain definite porticns of the work, such as cleaning out the houses, cracking corn tor the young chickens, grinding bones and oyster shells, carrying lood and water, and similar jobs, and of course when the coops were to be moved and work of that kind to be done, she was not expected to do much. But I found that that she was as strong as an average man, and a great deal more willing, so that it was impossible to prevent her helping us with everything. Her name was Margaret and she proved indeed a "pearl," and to her faithfuluess and intelligence much of the success of my experiment was clue

As soon as she came she entered earnestly upon her duties. The various yards were kept open or shut, as required, with great regularity; the breeding coops were visited regularly, the eggs removed and the nests kejt in good order, and all the birds, old and young, were carefully fed. She did not profess to know anything about the different kinds of food, and had no special notions about feeding and management. She had fed her chickens in the old country upon whatever she could get, and occasionally gave them a little pepper and old mortar pouncled up, but beyond this she luad no nostrums, and was ready to do anything that I told her. This made her invaluable, for it left me free to be guided by my own knowledge, and assured me that my phans and experiments would not be secretly thwarted by some one that thought she knew better tluan I did.

I fully realized that the financial results of my present stock, 
would depend, somewhat, on the way they were managed, as regards feeding. I looked upon the birds now in my possession as a mere means to secure a better flock next year, and therefore I had no hesitation about getting all I could out of them, and as soon as I could. After that I proposed to let them go.

If I had known much about their ages and qualities, I would probably have adopted a different principle in separating them into lots. I would have put those of the same age and the same time of moulting together, but as I had no information on this point, I was obliged to employ an entirely artificial classification. Hereafter, however, it would be easy to have all the hens in each yard of the same age, and they could be disposed of at once and together.

In talking with poultry keepers, I find the most diverse opinions prevalent in regard to the requisites for securing an abundant supply of eggs. Many hold that it is entirely in the breed; others place more dependence on the kind of food that is given.

I could not change the breed of birds now in my possession, but I could regulate their feed carefully, and I resolved to pay great attention to this point. My opinion was then and is now, that the best breed in the world will not give satisfactory results without special attention to the feed, but I also believe that a great deal of good food is wasted on worthless fowls. 


\section{feeding.}

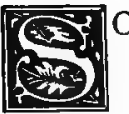

OME writers tell us that the hen is a mere machine for producing eggs-taking in corn at one end and turning out eggs at the other. Although this is rather a coarse view of the subject, there is a good deal of truth in the statement; and therefore it is very obvious that a hen cannot produce eggs unless her food is of the right kind, as well as right in quantity. Now, chemistry enables us to tell exactly what is wanted to produce an egg; it is simply the materials of an egg, and by chemistry we can easily find out what these are. Almost any ordinary food will keep a cock in good health and condition, but unless we give our hens the right kind of food, the supply of eggs will grow less. To produce an egg the hen must take in the material required for an egg, and unfortunately there is no form of food which will exactly represent an egg and no more. Now, whatever is over is waste, and must be got rid of, and if there is too much of this waste the system gets clogged up and disease or unfruitfulness is the result. Thus, if we feed our hens nothing but corn, in a short time they will become so fat that they become diseased, and egg laying ceases. But, if for part of the corn we substitute other forms of food, such as flesh, bones, cotton-seed cake, clover, etc., the number of eggs produced is greatly increased. All experience confirms this, and in our experimental coops we have seen it proved over and over again.

What, then, are the materials required to form an egg? In addition to the carbon, luydrogen and oxygen, which are found in large proportions in all forms of food, there is needed principally nitrogen, phosphorus, sulphur and lime. It is not difficult to supply plenty of these at a cheap rate, and in good form, if we only know how. Instead of a dissertation on chemistry, however, let us have a talk about eggs, ancl see what is needed for the different 
parts, these being the shell, the white and the yolk. The shell of the egg is made up chiefly of carbonate of lime. Our readers will find a full analysis in any work on organic chemistry, but with this we need not concern ourselves at present. 'The practical question is: Can our fowls get a sufficient supply of this material in their ordinary food, and if not, where can we find it? It is more than probable that those birds which are not fed by man, obtain in drinking water a large porportion of the lime used in the formation of egg shells. Almost all the water of streams, ponds and wells contains a small percentage of lime. And where the number of eggs is not large, lime in sufficient quantity may also be obtained from ordinary food. But where we want eggs in large numbers, it will not do to depend upon theses sources, and lime must be sup:plied as a regular article of food. It will not do to give the caustic lime used for whitewashing, however. We have known fowls to be killed by eating such lime. 'The lime must be rendered "mild" as it is called, by exposure to the air for montlss or years. Hence old mortar answers well, and all the better from the sharp gravel which it contains: By mortar we do not mean plaster or "hard finish," but the mortar used for building. A pile of this, if placed in one corner of the yard, will be constantly frequented by the hens.

Another excellent source of lime is found in oyster shells. They supply not only lime, but a small percentage of phosphorus* as well, and the fowls pick them up greedily. They can generally be had in any quantity for the asking, and are easily reduced to coarse powder or roughly broken by a hammer or stamper. In using a hammer, the best way is to place a heap of the shells in a shallow hox and hammer them-the hammer having a long handle-or they may be pounded with a pestle made like a pavior's rammer. 'This is a very efficient way. Or, if the fowls have access to a wagon road leading through the grounds, the shells may be simply laid down thickly all over the road way. The wheels and hoofs soon break them up and they make a very good surface to the road.

* Vide Watt's Dietionary of Uhemistry, article Oysters. 
These are all makeshifts, however. The best way to reduce shells to powder is to pass them through a mill made for the purpose. Such mills are manufactured at Easton, Pa., by Wilson Bros., for $\$ 5.00$ each, and will easily grind enougl shells in ten minutes to supply twenty hens for a week. A large portion of the shells is reduced to a very fine powder, and this should be sifterl out and kept by itself. The coarse chips are greedily picked up by the fowls, while the fine powder may be mixed with their cooked food in the proportion of a gill of powder to a gallon of food.

We have seen writers in the agricultural journals recommend bumt oyster shells for fowls Oyster shells consist almost wholly of carbonate of lime, and when burned this is converted into caustic lime. To give a fowl solid pieces of caustic lime to swallow is not a very prudent proceeding, to say the least of it.

Another important source of lime is bones. Bones contain both lime and phosphorus, and form one of the very best additions to our poultry food. The directions usually given for using them, however, are exceedingly wasteful. Most writers direct us to burn them, so that they may be pounded easily.* .To burn bones that are intended for food is a good deal like burning corn and feeding the ashes.t We prefer fresh bones, which are fed either cooked or raw. To cook them we fill a good-sized pot with water; put in the bones with as much flesh on as possible, and let the whole simmer gently, just as if making soup. When thoroughly cooked the bones are taken out, and the "soup" is made into "mush" with Indian meal. Such mush is very nutritious. The flesh is now cut from

* Since bones are composed cluiefly of phosphate of lime, with a very little cal. bonate, they are not rendered calistic by being burned, and consequently the objection which holis in the case of burned oyster shells does not apply to then. The process of burning is simply a wasteful one.

+ Parched or charred corn is, however, a very different matter. One of the best tonics for fowls, especially if they show a slight tendency either to constipation or diarrhcea, is charred corn. We have a large kettle, which we bought for old iron because it was cracked. in which we occasionally parch corn for our chickens. The kettle was roughly "set" in brickwork by our man, and the chimney is simply two lengths of old stove pipe, the whole being out of doors. A wooden cover keeps rain and snow out of the pot. A fire of brush soon heats the kettle so that it will char corn. Half a bushel is then poured in and constantly stirred until it is quite dark-partially burned, in fact. The chickens eat it greedily, and we feel certain that it does them good. of course we feed but small quantities of it. Occasionally, however, we find chickens that will not touch it. In that case moisten it and roll it in "feed." 
the bones, and the latter are passed through a Wilson mill. This grinds them up into a coarse powder, which may be either fed directly or mixed with the cooked food. As a general rule, the quantity of fine powder is not very great, and as the moist bones are difficult to sift we let the chickens do the sorting. 'They are greedy for bones or any animal matter, so we throw the ground bones into shallow boxes or troughs, and after they have eaten all they can pick up we dump the rest into the kettle of cooked food and stir the mass thoroughly.

There are several establishments that grind bones and ofter the " bone meal" or "ground bone" for sale. Most of this stuff is intended for manure, and is fit for nothing else. It is made from bones of all kinds-most of them so putrid that they "smell to heaven." Such material is; of course, totally unfit for food for animals. Some manufacturers, however, profess to prepare bone meal expressly for food for cows and poultry. The bones are fresh, they are ground at once, and the meal is thoroughly dried, so that any adhering flesh is prevented from putrifying. Some simples that we tried were quite sweet, and the fowls relished them and throve on on them. Other specimens seemed to make the birds sick very quickly, causing diarrhœa, drooping, and general ill health. We found, however, that a thorough boiling for at least an hour. rendered them quite wholesome, probally by destroying the putrefying agents. But in all cases it is best to get sweet fresh bone meal, and the best test for these qualities is to fill a saucer with the stuff, moisten it thoroughly, and see if it remains sweet after the lapse of two or three hours. Fresh meat will hardly putrify, even in a warm room, during an hour, but if it has been tainted already, and then dried so that it gives off no smell, and merely appears fresh, this test will generally lring out its evil qualities. Of course it should be kept in a moderately warm room; if exposed to a temperature below the freezing point it will not clevelop its evil features. The only simple and handy test that we know of is a good nose. A good nose is a most invaluable piece of chemical apparatus, and those who spoil it with snuff, tobacco, etc., do not realize what they lose. 
There is also found in market a very clean, fresh ground bone which is made from the bones after they have served the bone boiler, who subjects them to boiling under great pressure, and thus extracts every particle of fat and soluble matter. Such bones furnish phosphate and carbonate of lime, and not much else. Where ground bone of this kind is used the birds should have a. good deal of flesh during the winter months, when they cannot get insects and worms.

Passing from the outside towards the centre of the egg we next come to the white, which is a well-known glairy liquid, consisting chiefly of what is called by chemists albumer, which is merely the Latin for whiteness. 'To produce the white of one egg per day the hen must be fed with material which can be converted into that substance, and this must be furnished in a somewhat concentrated form. 'The question then comes up: Where can we find this in the cheapest and most available form? On referring to any good work on organic chemistry we will find that the different grains, etc., are valuable from this point of view in the following order :*

Decorticated Cotton Cake..........4 $4 \mathrm{I}$

Linseed Cake..................... 28

Beans....................... 26

Undecorticated Cotton Cake......... 25

Malt Dust.................... 23

Peas........................ . 22

Wheat Bran................. 14

Oats. ..................... 13

Clover Hay .................. I2

Wheat................... I I

Barley...................... I

Indian Corn .................. I0

Brewer's Grains, as ordiuarily solı . . . . . . 5

* This table differs materially from those given in most poultry books, but it will be found to embody the most recent and accurate conclusions of science, and since I followed its indications the results which I have obtained have been markedly improved. 
On looking over this table it will be seen that the foods ordinarily given to hens are not exactly those best calculated to produce eggs. Even wheat, which is usually thought to be one of the very best egg-producing foods, is lower in the scale than clover, and costs much more. The oats named in the table are the heavy English oals. Whether an average American sample would give as good results we cannot say. Oats have never been a fivorite fool with us, except for very young chickens, though in Great Britain they are very highly esteemed for this purpose. Cotton cake, when it can be had, is most excellent, and either cotton or linseed can be had in most places. In my locality cotton-seed cake is not known in market, but linseed cake, reduced to meal, is common. Of course these "cakes," from which the oil has been expressed, are comparatively poor in heat producing elements, when compared witl corn, wheat, or barley. The true way, of course, is to mix them, as we shall clescribe when cletailing our practice.

Last of all, we come to the yolk or yelk. 'This is a rich, oily emulsion, containing a liberal supply of phosphates. It also contains sulphur in a state in which it is easily set free, as is seen by the action of eggs on silver.

As is easily seen the egg contains within itself all the material necessary for the building up of a perfect bird; bones, flesh, feathers, claws, and every part of the complete animal is found in an uncleveloped condition in the egg.

Such being the theoretical requirements, it was evident that if there was any truth in the principles accepted by clsemists, I must provicle these materials abundantly, and of course in the clieapest manner consistent with the health and vigor of the fowls.

For the great staple food-that which to fowls is the staff of life-the various kinds of grain are ordinarily the most convenient, and, perhaps, when we take into consideration the peculiar digestive apparatus of the fowl, such forms of food are indispensable. Amongst the purchased food, therefore, grain of some kind must always form a large part, and I was, unfortunately, so situated that. I could not always take advantage of those opportunities which in other localities present themselves for getting damaged grain, 
sweepings, etc., at a low rate. "What is known as "refuse" grain or screenings, I found to be the poorest purchase that could be made. But in some localities, especially near great grain transporting centres, slightly damaged grain can be had at quite a cheap rate, and, if it has not lain too long, and is properly cared for when received, it is quite an economical article. It matters very little what the kind of grain is; every kind of grain contains enough fat, heat and force producing elements to keep the fowls in good health, and the necessary materials for eggs I could readily find in much cheaper and quite as good a form.

And by grain I mean whole grain-not ground. Meal, flour and grain that has been reduced almost to a pulp by steeping and fermentation, will not answer as a steady diet for fowls. 'l'his, I soon found out for myself, by experience, but others have discovered the same thing long ago. Ask any one who is in the habit of fattening poultry, and he will tell you that nothing adds to the weight of fowls like cooked meal, but that if confined to this diet for more than two or three weeks, the animals begin to lose flesh as rapidly as they took it on, and finally they fall sick. When fowls are taken from a wide range and penued up for fattening, the first effect is to make the birds lose fleslu. The cause of this is evidently the excitement and worry produced by the unusual confinement. As soon as this wears off, and the birds become reconciled to the new condition of things, they begin to take on fat rapidly. And here lies one great difference in value, in different individuals and breeds, as regards fattening. Some become speedily quieted down and quietly take to their food and rest. They doze away their time and grow fat. After a while, however, their digestion becomes impaired. The soft food causes no action of the gizzard, its secretions fail, and the bird begins to lose flesh. It should then be killed at once. For ourselves, however, we liave an intense dislike to coop-fattened poultry. No bird that has been penned up for weeks and fed on soft food can equal in flavor the flesh of one whose juices have been freshened by hillside breezes and the fresh seeds, grasses and insects of the roadside and copse. 
Aud we have never found any difficulty in getting our birds fat enough for our own taste and that of our friends.

In estimating the actual value of different kinds of grain for feeding purposes, we must remember that it is weight only that tells. One liundred pounds of one kind of grain may measure greatly more than one hundred pounds of another kind, and yet be greatly inferior to it in feeding value. Thus, as an egg producer, roo llbs. of oats would be better than roo lbs. of corn in the proportion of 13 to ro, but a bushel of corn would be more valuable than a bushel of oats, because it would weigh nearly twice as much, thus more than making up for the larger percentage of egg-forming ingredients contained in the oats. Indeed, I found that, taken as a whole, corn was usually the cheapest grain in market, and in buying, therefore, I confined myself chiefly to corn. I found that when it was supplemented with other matters which were not expensive it was probably the best. But corn alone did not answer well. The hens got fat and ceased laying. What I wanted, therefore, was phospliates and albuminoids; and the best and cherpest source of these, when they had to be purchased, was flesh and bones, and clover. I therefore made an arrangement with one or two butchers for a supply of bones and refuse meat, and continued to let the fowls have some of it for " dessert" at least every other day. The small bones were simply cleaned of their flesh with a knife, so far as it could be done without too much trouble, and then cliopped with a cleaver into pieces that would go in the mill. The Wilson mill ground them rapidly and thoroughly, and when offered to the fowls it was fun to see them rush for the feast. The meat from the bones, and also other pieces of waste flesh, were passed through a chopping mill, which cut them into small pieces, so that a fowl could not drag off a large lot at once and run all round the coop clased by its companions-each one trying to steal a piece from another. 'T'his happens only when the pieces are too large to be immediately swallowed. Nothing of the kind happened with meat cut by means of our chopper. The fowls swallowed it readily, each one got its just share, and all were happy.

Perhaps the cheapest form of flesh that I was able to obtain was 
young calves. In my district the farmers carried on dairying to a considerable extent, and as milk was too valuable they did not care to raise any calves, except promising young heifers. And as it was a criminal offense to sell very young calves, they were compelled either to keep them until they were some weeks old or knock them on the head and bury them in the manure heap. When it became known that I would give from fifty cents to a dollar apiece for them, at any age, I had as many as I could use, and this at a time too when they were needed-that is, just as my spring chickens were coming forward. The bones of these young calves are easily cut up-indeed, our meat chopjer sufficed for much of them-and an ordinary calf made two very nice desserts for 500 birds.

But in addition to these articles fowis need green food. My laying flocks, which were allowed to wander over a large range, did not suffer for want of this in summer, but during winter $I$ found it necessary to give them a regular and abundant supply, and at first I fixed upon the cabbage as the best vegetable for my purpose. At first I did not succeed very well in growing cabbage, the land not being rich enough, and the former owner not having paid sufficient attention to the saving of manure. Mrs. B. was so neat and orderly that the sight of a lawn coated with manure in the spring would have thrown her into hysterics, or some other womanly nonsense, and she would gladly have allowed all the manure to be given away, merely to get ril of the sight'and smell of it. As may be readily supposed, therefore, the arrangements for saving manure were none of the best. My views, however, were very different. Brought up in a country where the motto was "No manure, no cropss," I looked upon the manure pile as one of the most muportant things about the place, and to me a grass field covered with a rich coating of manure was by no means an unsightly object, because the intellectual beauty of the "eternal fitness of things" was more agreeable than the sight of a plot of ground thinly occupied with starved plants. One of my earliest "jolss," therefore, was to construct a good manure hed. This I began by staking off a piece of ground thirty feet by forty. The soil from this plot was removed, so that I had a pit four feet (lee; along one of the 40 foot sides, and 
sloping up to the surface on the opposite side. Along the 3 o foot sides the ground was cut nearly perpendicularly-the angle being only sufficient to keep the banks from caving in. The whole bottom was then puddled, and rammed hard and smooth with a rammer. The manure was thrown into this as fast as taken from the stable and cow house, and to it was added all such things as old nests, leaves, etc., etc.; in short, every kind of material that is valuable in making manure. It was astonishing what a pile we had accumulated by spring. The pit was not only full, but heaped up above the general level, and all except a few inches on the top was thoroughly rotten and fit for the land. It may easily be imagined that with so much purchased food of the richest kind coming on to the place the land was soon fit to grow anything, and after a year or two my vegetable crops were entirely satisfactory. But for the first two or three years I was compelled to buy my cabbage. Now, cabbages in that part brought a very high price though they could be grown very easily, and even at very moderate figures were about as good a paying crop as could be found. It was here, as everywhere else, however-it cost a good deal to sell them. I saw this point, and thought that perhaps I could make sone of my neiglibors see the point too. So I approached one of them, an intelligent young farmer ancl asked him what he would undertake to let me have 3,000 late cabbages for next season. He at once named eight cents, which was about the figure t'ley had brought in the market near us last season, when cabbages were pretty dear. I at once pointed this out to him, and suggested that as he ran no risk of losing the sale, and would lose no time in peddling them out, but would simply have to grow them and allow me to cart them away he ought to be able to sell them much. cheaper. But he could not see it; caljbages were worth so much in market, had been sold for that, and he dicl not see why he should not get the market price. As for my taking them away, that did not matter much to him. There would be but a few loads anyway, and his teams might as well haul cabbages as stand idle. Of course such a price placed them beyond my reach, and I at once turned my attention to something else. But as the previous year had been an 
exceptionally good year for selling cabbages, and the price was very high, everybody planted a patch this year, and several of my neigh. bors planted quite extensively. The result was that the market was overstocked, and I bought my neighbor's cabbages and had him deliver them for less than I had offered him in the spring, \$35 per $\mathbf{r}, \infty 00$. When he drew the last load and got his pay for them, he remarked that he was done with cabbage growing; would never grow another one except for his own use. I then asked him what he would grow me the same quantity for next year, I to take them away as wanted? He said he would think the matter over and let me know. In a few days he came to me and offered to grow 3,000 heads for the same price that I had offered him the year before$\$ 42$ per 1,000 . I closed with him on the understanding that all the heads were to be good saleable heads, any poor ones to count at the rate of two for one. This gave me a head of cabbage for every bird I raised that year, and I found it none too much. But this is anticipating.

Meantime I had determined that if I could not grow cabbages I would grow something else, and I fixed upon clover. Experience had slown me that this plant formed one of the very best foods for fowls, and as it could be made to produce a very heavy crop per acre I believed it to be one of the most profitable. Thirty-five bushels of corn, which, at $5^{8} \mathrm{lbs}$. to the bushel, would give 2,000 llss., may be considered a fair yield for an acre. I have raised four times this amount of dry clover from an acre, and the percentage of egg forming elements in the clover is greater than that of those in the corn.

I therefore resolved to raise clover as an egg producing food and as green food. There were some other plants that suggested themselves, but as clover and I were old friends, and as I saw several vigorous plants growing on the place, I felt sure that I could grow clover, and I did not care to try any "side" experiments at this stage of my venture. I had neither the time, the money, nor the inclination.

The reader may, perhaps, have noticed that in speaking of my manure pile, I said nothing of the hen manure-by far the most 
important article on the place. In order to fully explain my plans and the reasons for this admission it will be necessary to digress a litule

It is a well known fact, that many of the parasites and liseases which afflict man and the lowel animals, are propagated and disseminated chiefly, if not wholly, through their excrements, and in many cases the parasite adheres to the vegetable which forms the food of the animcll, and is swallowed with it. A curious instance of this is the fluke, which is so fatal to sheep that are fed on marshy ground. The fluke is a parasite whose history we may trace from the time when it makes its home in the snail; the snail crawls out on the damp grass and is swallowed by the sheep. In the body of the slyeej), the parasite matures, forms its eggs and discharges them-a single fluke originating as many as 40,000 eggs. These eggs are carried by winds, rains, the hoofs of animals and other means into pouds, ditches, etc., where each one develojs into a fiee-swimming embryo, that, after some changes, passes into the body of a snail, there to pass through further changes, and again take up its journey through the circuit of its existence. From this it is olvvious that'a single "rotten" sheep-that is, one afflicterl with flukes-is cilpable of infecting an entire field, and of carrying disease and death into a large flock.' 'The same is true of a diseased chicken. In the chicken the "gapes" are known to be caused by a parasite. 'The eggs of this parasite, passing through the chicken fall on the ground and are picked up by other chickens when they are taking their food or swallowing gravel. The sime is the case in regard to true chicken cholera. This disease is caused by minute organisms which infect the intestinal canal of the chicken, and which are voided in millions in the excrements of birds so afflicted. It is easily seen that any other chickens feeding on such soiled ground, or eating the green plants grown thereon, will become infected in the same way. And, yet, one writer actually tells us that chickens should be made to. scratch over their own excrements and pick out the gravel contained therein, so as to save the trouble and expense of providing fresh gravel!! 
In all my chicken raising, disease has been my great dread, and perhaps it has been on account of my dread of it, that I have succeeded so well in avoiding it. With me the "ounce of prevention "has been always greatly preferred to the "pound of cure." I believe that, for man, it is exceedingly dangerous to eat raw vegetables that have been raised on ground manured with niglst soil, or sewaige, or even the excrements of pigs, and it is my belief that many obscure cases of disease in our large cities arise in this way. And if possible, I would never allow any animal to feed directly off ground that had been manured with the excrements of others of of its kind.

Especially is this true of chickens. The proper crops to grow on ground that has been manured with night soil or sewage are the cereals-wheat, barley, oats, rye, etc. Lettuce, calbbage, turnips, etc., should never be grown on such ground.

The reader will now appreciate my reason for keeping all the chicken manure by itself. 'To stilize it I determined to grow corn, while my stable manure I applied to the clover crop. It was evident that while these minute but destructive parasites might readily adhere to the moist and succulent clover, or even to the foilage of corn grown for soiling purposes, they could hardly reach the kernels of the corn. The washing rains of spring, the scorching suns of summer and the drying winds of autumn, would give them but a slight chance compared to that which they would have on the moist clover, always moist from its proximity to the ground.

And, here came in one great advantage of the portable fence. I could plow up a corn patch of any size and allow the chickens to revel amongst worms and grubs to their heart's content. 'Then it could be fenced in, planted to corn and cultivated until the corn was high enough to admit broods of small chickens which were easily colonized in it. As soon as the corn was harvested, the fence was removed, and the hens allowed to pick up all that was left and rummage the whole patch for bugs and worms.

There is no manure, that I know of, that will produce a better crop of corn than will hen manure. We always had plenty of it, and we tried to put in as much corn as possible, for in addition to 
the grain for our fowls, we had the stalks for the cow, and the cobs for kindling - a most' useful article in our position, and there is' no. better kindling than dry corn cobs.

My experience with the artificial foods, or so-called "egg-fools," lias been so limited that I have little information concerning them to give the reader. At one time I tried $25 \mathrm{lbs}$. of an egg food that is extensively advertised and highly recommended, but the results did not warrant me in repeating the experiment. It must be borne in mud, however, that it is exceedingly difficult to determine questions of this kind. The incliviclaal characteristics of the members of any flock may have quite as much to do with egg production as has the food given to them, and there are so many other conditions which it is exceedingly difficult at all times to observe or to control, that the results must always be somewhat uncertain. The experiment in my hands was not carried out with that attention to details that would preclude all error. The way I did it was this: I selected two coops and yards of exactly the same size and similar location. I then chose fourteen hens as nearly alike in age, size, breed and general appearance as possible. 'This flock was then divilled into two lots of seven each, the best hens being drafted altemately for each coop, just as boys used to be drafted under their several captilins for some contest. The best went into $\operatorname{coop} A$; second best to coop $B$; third best to $A$; fourth best to $B$, and so on until all were drafted. These two lots were then fed and treated in all respects as nearly alike as possible, except that one lot was fed with egg food, and the other had what was supposed to be an equivalent in wheat bran. The experiment was continued until 25 lbs., of the food had been used. At first the fowls that had the egg food produced considerably more eggs than the others, but after a time they fell behind, and at the end of the experiment the two flocks were very nearly even.

The conclusion that I reached was that " egg-food " consists chiefly of stimulants, and that the use of these, heyond a very limited extent at the beginning of the season, is an injury rather than a benefit to the hens. The high price of most of the "foods" in market precludes their use as food, while for a stimulant we have never 
found anything better than a little red pepper. Even this, however, we used sparingly with our laying flock, and still more so with our breeders; warmth, both in the way of food and housing, together with good nourishing food, are the best stimulants, and if the breerl of fowls is right, they will, under such conditions, satisfy any reasonable person.

The water used on the place was of the very best quality-clear, cold, spring water, with just enough mineral matter in it to remove the bad effects of rain or snow. It came, of course, from the spring which I have already described, and as a general rule the fowls got nothing but this water to drink, but when confined in very small coops and yards I used the famous Douglas mixture with great satisfaction. This consists of

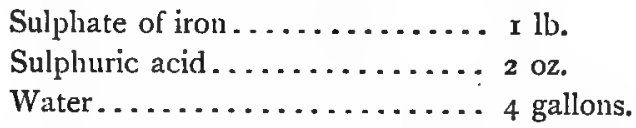

The sulplate of iron was dissolved in the water, the sulphuric acid added, and the liquid put up in quart bottles kept tightly corked,* A teaspoonful of this mixture to a pint of good water seemed to have a most excelleut effect.

I found, however, that by lessening the sulphuric acid to one ounce, and adding two pounds of soluble phosphate of lime, I got a mixture that was far superior. The phosphates that I used were those sold by the Rumford Chenical Works, of Providence, R. I., and being intended for consumptior by human beings, were no doubt more expensive than was necessary. I presume, however, that if a demand should arise for this compound, the firm named could furnish it at a price which would render its use profitable.

One of our great difficulties in feeding was the distribution of the

* Sulphate of iron, when exposed to the air, is apt to absorb oxygen and probably ammonia. The iron, which is the really valuable, part, then becomes insoluble, and is not taken up by the fowls, but adheres to the sides of the vessel. Hence, the reason for keeping it in small packages securely corked. The use of the sulphuric acid is simply to keep the iron in solution. If the iron rust be mixed with scalded bran, meal, potatoes, etc., it will be eaten and will do the birds good. Too much of it is injurious, but a teaspoonful of red iron rust in the food of six large or ten small fowls once or twice a week is very good. 
food; some hens would get more than their share, others would get less. I was astonished to see the difference between fowls in this respect. 'lake any two dozen fowls, throw down a pint of corn, and after it has disappeared examine the crops of the birds and you will find that half of it has been picked up by half a dozen fowlsthe remaining hilf being divided amongst the other eighteen. Still worse is this in cases where the birds are called off the perch by throwing down food. Some wide awake, early risers will get all they can eat, while others will remain on the perch and get nothing, or they will come down in such sleepy fashion that breakfast is over before they are reaidy.

After a good deal of observation I found that the more widely the food was scattered the better was the chance of each individual bird. I therefore arranged it so that when grain was fed it was sown broaclcast over a consislepilble space, and when the food was soft it was placed in a great many sm..ll dishes or troughs, so that weak birds were never in danger of being crowded away by the stronger ones.

It is very evident that if there were no oljection to giving every bird all that it would eat, the matter could be arranged very simply. All that we would have to do would be to keep food constantly accessible to the fowls in well-protected feed boxes and the work would be done. And this, indeed, is the method adopted by many. One book on poultry, now before me, has page after page. devoted to the description of self-acting feeding hoppers, and dozens of amateurs that we have met have pointed with pride to feed boxes of marvellous ingenuity and utter worthlessness - " made. with thei; own hands," and supposed to be a convincing proof of their titls. to the honor of being considered skilful poultry keepers. Observ ant poultrymen have long since found out that hens may be alto. gether too fat to lay; that they must be kept on such a scale of diet as will maintain them in constant activity-always, ready for more, like Oliver Twist. In fact, one of the secrets of successful poultry keeping consists in striking this golden mean between excessive fatness and starvation. A very excellent system, one which has been in vogue for many years, though frequently described by 
recent writers, and of en claimed as original by them, is to mix the grain with cut straw, leaves, or other light rubbish, and make the hens "scratch for their living." It is a most excellent plan, but requires special arrangements to maks it succeed in practice. All such scralching grounds must be protected from rin, snow, etc., and must be separate from the dusting baths. My feeling grounds were simply sherls, cheaply constructed of stout poles and thatched with evergreen boughs, obtained in thimning the belt of everḡreens which protected our northern boundary. If properly laid, such a roof is almost perfectly rain-proof, and the bircls can always find plenty of room. In summer, therefore, we relied upon these feeding places, of which there was one to every 100 hens. In locating them we chose the most burren and driest places we could find, macle them a good size, and liberally strewed them with chaff, pine shatters, leaves, etc. 'l'he food strewed on these places was generally cracked corn or whole wheat; anything of a smaller or clarkẻr grain was apt to be lost, while whole corn was too easily found, and at any rate $\mathbf{I}$ did not feed much whole corn, except on winter evenings and very cold day's.

'The feeding sheds were placed so as to face south-south-east, so that they always caught the early morning rays, and by afternoon they were partly in shade. The early rising hens always mate for these places the very first thing, as soon as they hat their liberty, but we fomd that this would not clo; these early risers would clean the whole food out before the others got a cliance. All the hens, therefore, were kept in their own yards, until the entire flock had come off the roosts, and to expedite this, a little grain was scattered on the ground and the bircls called to it. As soon as all were clown the gates were opened, and those that wanted further feed scampered off to the sheds. They lay about these sherls and scratched, went to the dust-baths, rummaged the leaves for insects and wandered about freely until evening, when they were again fed all the grain they would eat. This was our usual summer routine, and it was very rarely that they did not return to their proper houses to lay. In addition to the nests in the houses, we liad special boxes scattered over the grounds for 
their convenience, but we did not get many eggs in them. Ninety per cent. of the eggs were laid in the houses.

In winter the programme was, of course, considerably varied. When the snow was deep many of the sheds were inaccessible, but when the ground was clear they were all frequented cluring the day. Instead of sending the heus off hungry to their feeding grounds, however, I gave them soft feed, well cooked, and consisting of corn meal, bran, ground oats and rye, flesh, bone dust, finely powdered oyster shells, etc. Of course the proportion of the latter ingredients was small. A little salt, and sometimes a little red pepper were also mixed with the food. This was made into a very stiff paste, being, in fact, worked like baker's dough, and was then placed in troughs, which were made in very simple fashion

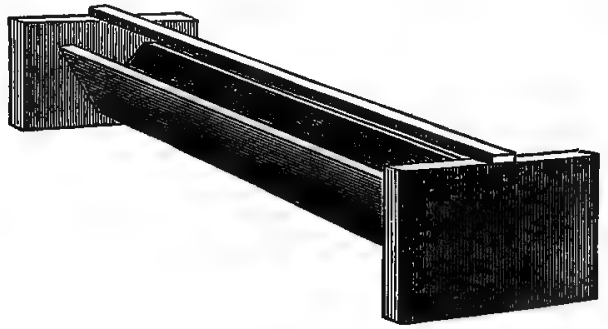

Fig. 11.

by nailing two narrow boards together along the edges, and closing the ends by means of two square pieces, as shown in the engraving, Fig. $\mathrm{r}$ I. In order to prevent the birds from getting their feet into these troughs and defiling the food, I nailed a strip across the top as shown in the figure. It answered the purpose admirably. All our birds, without exception, would rush for these troughs, so that even the slowest feeders got their share. They then went to scratching in the feeding sheds of their yards, and in this way got plenty of exercise.

When the snow was on the ground, and no green food was to be had, we hung cabbages all around the sheds and let them peck away at them. We also mixed some very finely cut dried clover with their feed. By passing it through a feed cutter and also through a mill, we got it down almost to a powder. 


\section{full Broodg.}

in many departments of agriculture, it is a good rule to find out what others are doing, and then do the opposite. If everybody is plinting potatoes, then plant no more than you need for your own use; if nobody is setting out cabbages, set out all you call. Now the great bulk of the chickens that are raised in this country are hatched in May and early June; too late to bring the highest price for spring chickens, and yet so early that by next season they will have eaten more than they are worth.

While sitting in the shade of our porch one afternoon, I recalled an experience which I had had a few years previously. We, at that time, occupied a beautiful place of about $3^{\mathrm{I} / 2}$ acres, and kept a number of hens. Of course we did as others did, and every spring we ra sed enough chickens to supply our table during fall and winter, and to furnish pullets for next year. One day, late in September, one of our hens came into the barn yard leading fifteen beautiful chicks. She had stolen her nest and hatclied this brood, and as she led them up to where we stood she seemed to say, as plainly as if she had spoken in good Einglish, "Is not that something to be proud of?" Well, I thought it was. So I fed the little flock, gave them a nice warm berth in the stable, and made every provision to bring them up. Several friends who called to see us, and who professed to be well versed in chicken lore, advised me to kill them at once. They bever could amount to anything, they silid; the cold weather would come before they were fledged, they would probably die, and it they should survive, they would only be scrubs; therefore better kill them now and be done with it.

Killing animals in cold blood, merely for the sake of getting rid of them, is not my forte. I have killed a good many animais 
in my time, but to deliberately kill a nice little flock of chickens, and throw them in the manure heap was a kind of killing rather different from anything I had ever done before. So I let them live; their food, poor little things, did not amount to much, and for the present, at least; they seemed supremely happy. They grew apace; when the cold weather came, the mother abandoned them, but we stretched an old blanket on a frame which supported it about three inches from the floor, and they crept under this and kejt warm. We gave them specially rich food and all the tid-bits from the table, but the older chickens robbed them, so I made a coop with a hole through which they could easily passs, while the older ones could not, and we placed the food under that and they could eat whenever they wanted to. We lost five by various accidents, but when I went to the stable on Christmas morning to give my animals a Christmas greeting and a Christmas breakfast, there were ten as fine young birds as I ever salw-four cockerels and six pullets. They throve well in spite of the cold weather, and in March the pullets began to lay, and kept on laying when eggs began to grow scarce and other birds ceased. The cockerels, were plump and delicate-far different from the previous spring birds, which had now become somewhat rank and tough. At this time common poultry was selling for 20 cents per $1 \mathrm{~b} .-3^{\circ}$, per cent. higher than it had brought in the fall-but for these birds we could have got more. And so I concluded that the best paying brood on the place-that which had given least trouble and had. brought most profit - was the brood that came from the stolen nest.

Now, I had noticed that several hens in the different houses 'wanted to sit, so I decided to hatch out three or four hundred young chickens this fall and see whether or not the operation would be a profitable one.

I therefore filled out my, former hatching, room with hatching. boxes, similiar to those previously described, and gradually filled them up with hens. I managed to place in it twelve boxes, holding forty eight hens. In expectation of the young broods, I had a lot more of the brooding coops made so that I could care for the chicks under any circustances. 
As I had taken great pains with my breeding pens, and the weather had been quite favorable, the hatches were, whitt I called, very good. They averaged nearly ten to each hen, giving me 473 chicks. These I divided amongst thirty seven hens, giving an average of thirteen chicks to each.

Our system of caring for the chicks was as follows: The date of setting and the date when due being clearly marked on a carl tacked to each nest, there was no room for mistakes. When a hen was due she was not removed from the nest for food, but was allowed to sit until she came off of her own accord. I allowed very little meddling-the only thing that was permitted being the removal of the empty shells. Young chickens need no attention for twenty-four hours after they leave the shell, and if left fortyeight hours they will not suffer. 'This is no doubt a wise provision of nature, wherelsy the birds that do not come out as soon as the others are not left to be chilled. When the ben led the young brool off, they were fed with cracked corn, ${ }^{*}$ from which all meal and dust had been carefully siftel. An hour or so after this they had all the chopped meat they could eat with phenty of clear water. At this time we unfortunately had no milk, and could not get any conveniently. 'This was a mistake, as I soon found, and ever afterwards I contrived to have plenty of milk on hand when I expected to hatch out many brookls. But on water, corn, meat and bones they thro:e very well. When set on the grass, they could pick plenty of green stuff, and by the time the weather got too cold, they were able to peck at a cabbage with good effect.

A favorite morning food was macle by scalclin? horse feed, allowing it to stand until stiff, and working it into stiff dough with more dry feed. 'This they ate greedily, and throve well on it. I found that by keeping the hens from wandering about and leading the chickens with them, the latter got along much better. Meat

* Most writers advise anf $l$ food fur the first meal. I have found that we have better success when we tise a hard food. The young chickens naturally do not find soft food; they need something hard and solic to excite the gizzard to action, and after that give them the richeat and most nitritious food posslole. 
scraps well chopped up seemed to be quite as good as insects. We also gave them liberally of fresh ground bones, which we prepared ourselves in one of the Wilson mills. This was before these manufacturers had brought out their small mill for grinding fresh bones; but by cooking the bones thoroughly they were easily scraped clean and ground up, and the soup was mixerl scalding hot with feed into a stiff dough which was fed to old and young.

Before very cold weather came these chickens were well feathered and quite large. I found occasional çustomers, at good prices, for a pair of cockerels for some invalid, and though this was an uncertain market, yet I was surprised at the number that I sold in this way. When spring came $I$ went to a noted restaurant in a neighboring city and induced the proprietor to put up a sign :

\section{"Fall Reared Chickens-Tender and Delicious,".}

and in a few weeks they were all gone.

I kept the pullets by themselves until the end of February. With an unusual degree of forgetfulness, I had neglected to prepare two yards for them in the fall when the ground was soft, so there was nothing for it but to keep them in a loft during the very cold months. I had $\times 87$ of them, and they were rather a mixed lot, as I had taken the eggs just as they came fiom the breeding pẹs without much care in selecting them. But early in March some of them began to lay, and I saw that it was necessary to them into regular houses and yards with proper sheds, etc. I therefore had two more of our regular houses put up. I had plenty of fence panels, but I could not drive stakes as the frost was not yet out of the ground. So I tied the panels together, and put them up zig-zag fashion, like an old Virginia rail fence. I found that they stood quite firmly, and ansue:ed every purpose fert a temporary expedient. I then dividerl the pullets into two and put one in each house, and fed for eggs. During the next month or so they did not do any better than the other hens,' if as well. But after that time they went on increasing, and when eggs 
began to grow scarce, these two pens supplied us with twice as many as any other pens containing the same number of birds.

I was therefore very well satisfied with my experiment, aud every year since that time I have always raiserl a large number of fall chickens. I now keep them in a large house until the price of the old fowls goes up. I then sell the latter, and replace them with the young pullets. 


\section{(1) wr first Winter.}

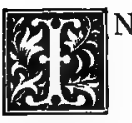

$\mathrm{N}$ northern climates it is the wintering of his stock that tests the ability of the stock raiser, and decides his profits, and this whether it be cattle or poultry. A few dozen hens can easily be kept in a lean-to shed next the cow stable or barn, and they may be kept warm and well fed and prove a success. Every shed on the premises will be frequented by the birds, which will thus find plenty of shelter and diry spots without any necessity for the owner putting up special buildings, but, when the number of fowls is large, these resources fail, and the ustral results of crowding and cliscomfort make their appearance. I had had a very unpleassant experience in regard to this matter at one time, when, after raising two or three hundred chickens, I attempted to winter them, without providing the necessary shed room. I had, therefore, been careful to attach large commodious slreds to all my houses, and to make the access to these sherls so convenient that the fowls would have no snow and sleet to pass over in order to get to the feeding grominds and dusting baths beneath them. I also allowed the large temporary sherl to remain, as I knew that it would be a great boon to the young chickens until they were properly disposed of.

'The nights had now began to get chilly, and frosts had come with the October lays. Our latest broods were too delicate to stand the chill autumn night air, though on bright days they enjoyed basking in the sun. We still kept many of them in the wirecovered bronding coops, lsut to the older ones we had given the liberty of the place. I provided very warm comfortalle places for them to nest at night, although most of these were rather of a make-shift character. My standard coop for this purpose, however, one that I could obtain easily in any cuantity, consiste. I simply of one of the cheap barrels used for packing app;les, etc. 'Thus was 
laid on its side and steadied with stones or blocks on each side, and the open end was covered to within four inches of the ground with a curtain male of the maiting that comes round tea-chests. 'This matting can be had for almost nothing' at the tea stores, and three thicknesses of it make a screen that is impervious to wind, rain and snow: These bariel coops were placed in different spots about the grounds, but always where the shelter was gooul. On wet and cold days the little flocks used to stay in then a large part of the time. Food and water were placed near them, and with the number that I now had, it was not very difficult to attend to them. On bright sumny days it was no trouble at all. On rainy days it was rather an uncomfortable job. I had heavy rubber boots and a rubber coat, and I provided similar garments for Margaret, so that she could always keep dry, ancl we managed to get along, but I saw that if my experiment of fall broods proved a success, I would have to erect a cleap board house with green-house sash in the roof, and attend to the chickens in that. One writer ridicules the idea of protection being required for the attendant, but he seems to forget that human beings are not macle of cast iron, and that even chickens suffer from wet and cold.

The early hatched chickens were now full grown, and the cockerels gave us unmistakable hints that it was time to separate them from the pullets. So I had some more portable fencing made, enclosed the large slied, and kept them in that. They were well fed on rather fattening food, so as to prepare them rapidly for market, and we got rid of them as soon as possible by methods which the reader will find detailed in the chapter on marketing. To the pullets we allowed the range of the place, but we found that although the nights began to grow cold, and even after snow came, they would persist in roosting in trees and on fences, and it was almost impossible to get them into the houses. Night after night we carried them into a house and placed them ou the roost, but next night they would be found in their own place the same as ever. The worst of it was that they were excellent fliers, so that nqne of our fences would keep them in.

I got over this difficulty by catching them one by one, shaving 
off the feathery part from the quills of one wing, and placiug them in the old house where there was most room. We had to lock up the entire flock for ten days, but at the end of that time when we let them out we had no trouble.

I was anxious to leave the poultry at liberty as long as possible, so though November brought wet and dreary days and a few flurries of snow, yet the clickens did very well. Many of them moulted and consequently stopped laying, but I was, surprised at the number of eggs that we got every day. The number of hens. on the place was a little less than 6.00, and of these two-thirds must liave been laying for many days; we got twenty and twentyfive dozen eggs. At this time it was our practice to shut the hens in every night, and keep them in until late in the morning. As soon as they were let out, they had a warm feel of clough madé by scalding a mixture of corn meal and oil-cake, and adcling a little of the siftings of ground oyster shells, and a little red pepper. At noon they had wheat, as much as they could eat.' At night a good feed of whole corn. On fine days they had free access to the patch of clover and grass, and on wet days they had cabbages, as much as they could eat. Twice a week they had all the meat and ground bones they would eat after their, dinner of wheat.

Under this regimen they throve well, and became very bright and.vigorous. The egg crop increased to thirty dozen per day, and as eggs were bringing a good price (35 cents per dozen) we much more than paid expenses. At this time (Nov. 25 th) we had on the place over 1,200 head; some of them, however, quite small. The feed cost about $\$ 4$ per day, besides labor, and the returus were over $\$ 10$, so that the result was on the whole quite satisfactory. As we were disposing of our cockerels quite rapidly, the amount of food required was also lessened.

This experience, however, was somewhat exceptional.' Under. ordinary conditions the egg crop) would have kept growing leșs and less until the revival in Felsruary and March, and it was evident that under the stimulus of more liberal feeding than they had been previously accustomed to, and also the influence of red pepper and 
bones, their latent powers were being developed. How long they could stand this, however, was a question.

Real cold weather dicl not set in until after the middle of December, and then it was ushered in with a rather heavy fall of snow. This prevented all access to green stuff growing in the fields, and confined the hens to their houses and sheis. And here the glass roofs came into play with striking effect. While all was cold, wet and dreary outsicle, these glass covered sheds were lry aud warm. We made a stout snow plow, and wilh Madge's aid we opened up paths all round the place, so that Margaret could reach'every house without any trouble.

As there was but little outside work for the man now, we kept the boiler going all the time, and we ground up bones quite liberally. As the birds were somewhat crowdesl, we pickerl out a few that we thought the poorest, and fittened them up, and got rid of them. We also got rid of the last of the cockerels, except the very young ones, ancl in this way we macle more room for the rest. But in spite of all our efforts and extra feed, the egg crop diminished; the cold snap proclucel a remarkably sudden and great change in the birds, and our receipts frequently fell from thirty to less than ten clozen. But, as the number of eggs produced grew less, the price increased; forty, fifty and at last sixty cents was reached.

Thus far our fowls kept in good health, but then, as we well knew, the worst was to come. It was the cold of February and March that I dreaded worst.

In the large houses the hens kept very comfortable. But in the breeding pens the birds began to suffer with the coll of January. The snow left us about the 8 th of January, and we had some very, fine weather about that time. In a few days, however, it grew cold again, and was much more severe that it had previously been. The birds in the breeding pens, having no glass sheds, were compelled to go out in the open air whenever they left their coops, and the combs and wattles of the hens got frozen, so that laying entirely ceased. And as I was very anxious to get eggs from these coops, so as to be able to raise some very early pullets, that would 
lay next winter, I confess I was taken quite aback at this new obstacle. Indeed, so serious was the difficulty, that I almost gave up all hope of succcss that season.

It was an awkward predicament to be sure. What could be done?

I saw at once that all hope of intelligent crossing and breeding from these hens was at an end, so far a's early chickens this season were concerned. I, therefore, decided to rearrange some of my yards, and make up one almost entirely of laying hens; and in this I put several of my best cocks. I know that this is not an alvisable system, but I could not very well do otherwise. To have more than one cock in a coop is very unwise. They prevent each other from paying attention to the hens and this causes many of the eggs to prove unfertile. But I could not very well help it, and so I had to arrange as best I conld.

The neglect to provide for my breeding stock was my first great blunder, and the one that did more than anything else to retard my progress. It was a mere oversiglyt; I knew better, but I did not realize the necessities of the case.

The laying hens, placed in one of the large houses with glass shed, etc., soon supplied us with eggs for setting, and as we always had liens ready to set, we soon had our early broods under way. Of course they would be a mixed lot, but as they were all gool, we had considerable hope of fair results.

So far as our sixty breelling hens were concelned, there was nothing for it but to give up one of the warmest houses to them, and keep them in that. So I picked out the most convenient house, distributed the hens amongst the other houses, and transferred all my breeders to their new house. "l'hey were left there without any cock until they began to lay again freely, which was not till late in February. Meantime I put up small glass covered sheds against the breeding coops, made everything still more snug and warm, and, in short, made the small coops as much proof against the weather as the large ones. I then gradually transferred the hens back to them, and although I did not raise my earliest chickens 
from the eggs of my best hens, yet I was able to get several very fine broods in April and May.

It is a well known fact that a hen that gets her comb or wattles frozen, will cease to lay until the sores are healed. I found that fowls with rose-combs, as they are called, were much less liable to freezing than those with large single combs, and one of my greatest objections to the Brown Leghorns, is their enormous combs, which are not only long, but very thick and fleshy. But I found that a young bird that had been "dubbed," as the cock-fighters call it, stood the frost much better than even the rose-conb. After the first winter, therefore, I "dubbed" all my fowls-that is to say, I cut the combs and wattles off with a pair of shears. The pain cannot.lye very great-not nearly so much as the large sores caused by being frost-bitten, and the operation is easily and quickly performed. A single cut removes the entire comb, and the wound is then dusted, with a powcler made by roasting one part of sulphate of iron, and three parts of alum in an old pot. This mixture is then reduced to a fine powder, and kept in a closely corked bottle. A little is put in a small box, and used as wanted. It is an old and famous styptic (a medicine for stopping bleeding), aud was in great request amongst the warriors of old, who were often compelled to be their ow surgeons. Care must be taken that it does not get into the eyes of the birds, or bad results will follow.

While hens frequently stop laying in very cold weather, it was long ago proved by Reaumur that mere warmth will not induce a hen to keep on laying during winter. In laying, as in all similar physiological processes, a period of rest is needed, and without this ordinary breeds of hens cannot. lay. Knight proved this law, even in regard to plants, and showed that if we want to force plants successfully, we must first give them a season of rest, and this may be done by shading, cold and dryness. I have always thought that a large part of my success in getting eggs the first winter, was due to the fact that the hens stopped laying after I got them, and hence had their needed rest at that time.

That cold alone does not prevent hens from laying was clearly shown this spring. In Feluruary and March the weather was 
colder and more serere than during any other time, yet it was during this period that we got most eggs from the hens that were on the place when I got it.

As the season wore on, the eggs to began to increase again, but the price fell until it scarcely paid for the tear and wear of the hens. The price got as low as 16 cents per dozen, so that it took 25 dozen to pay for feed alone.

When the first days of April came and the snows of March had clisappeared, we were all impressed with a feeling of great relief. 'The birds could again wander over the entire place, and the prospect of green food and plenty of insects was eucouraging, even if the reality had not come. Our losses had been but slight, considering the motley composition of the flock-ill ages, sizes and conditions. We lost twenty-six old bircls - a little over four per cent.and this, I thought, was not a bad showing. They died with various symptoms-all evidently caused by severe weather. In the matter of chicken diseases, I do not profess to be an expert. When one of my birds shows signs of: ill-health, we place it in warm quarters, give it pills made of cayemne pepper, butter and bread, and then feed it on soft food and clean water. If it improves (and they generally do) in three or four days, all right: If not we chop its head off and bury it where the other chickens cannot get at it.

The farmers, and especially the "suburban" residents, now began to buy chickens for laying, and paid good prices for them. They tliought in this way, to save the labor and cost of wintering them, and perhaps they did. But I had no objection to sell those of my fowls from which I had taken as much good as I was likely to get, and so I made up a few crates selected from the different houses, and in this way I reduced my stock very considerably. 'The broods of last spring and summer were now laying, and the fall broods were coming on quite rapidly, so $I$ thought it as well to dispose of some of the least valuable of my stock. 


\section{Nrests and NTegt Eggs.}

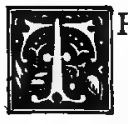

HE nest of every bird is primarily designed for hatching and rearing its young. The use to which we put the laying nests is not one designed by nature. This being . the object, the bird likes seclusion, and always plays at "nesthiding" when it can get a chance. No one ever fouud a stolen nest exposed to the full glare of observation; it is into dark corners and out of the way places that nature leads the bird. And yet I have seen otherwise intelligent men place the nests of their laying hens so that they were fully exposed to view.

During the heiglt of the laying season the nests in the houses did not give the birds quite room enough, and I never like to see two birds on one nest, so I had an extra lot of the hatching boxes made and placed them in the sheds and against fences, but at such a distance from the latter that the hens could walk in between the box and the wall and so reach the nest.

To examine these nests, or to collect eggs, it was not necessary to go in front of the boxes; all we lrad to do was to let down the hinged board and everything was within reach. If, on first opening the door, a hen was seen on the nest, the door was gently closed again, and she was left to her own meditations.

In making nests for both the laying and sitting hens, we used a fine kind of grass or hay that is used for packing glassware, and can be obtained in moderate quantities from almost any crockery store. Conmon straw is too coarse; if chopped short the cut ends irritate the hen, and if left long her feet get entangled in it, and the eggs get broken. Pine shavings make a fair nest, and the turpentine keeps away lice. But fine grass, dusted with sulphur, cannot be excelled.

The nests of both our laying and sitting hens were made directly on the ground, or, if on a floor, a sod with the grassy side up was 
placed on the bottom. On this was placed a layer of fine grass, and the whole well dusted with sulphur. As soon as the chicks come off, the nests should be removed, and either burned or buried deeply in the manure heap. The sod keeps the eggs damp, but if on a floor it gets too dry, and after a time the eggs should be sprayed with water when the hen is off. Our spraying apparatus consisted of a pan of water and a small whisk broom. Some wise,acre has asked: "Who sprays the eggs of the wild bird and the stolen nest?" to which sapient conuudrum the answer is obvious. The hen herself does it. Wild birds rarely make nests until the grass begius to grow and the morning dews begin to fall. 'Ihen when she leaves her nest it is generally in the early morning, when nocturnal enemies have retired, and while as yet the animals that prey during the day have not come forth. She steals along through the grass, fearful of being observed, picking up stray' seeds, 'worms and bugs, and when she returns the eggs may not liave been sprayed, but she has been, and that amounts to the same thing.

Concerning nest eggs great differences of opinion exist: We have heard successful poultry keepers ridicule them most unmercifully, and we liave known others of equal experience who believed them to be of great advantage. Our own view is that hens will not lay. quite as many eggs without nest eggs as with them. It is true, when the egg is fully formed, the hen must lay it or lose her life. So that if hens are confined in small pens, and are thus prevented from laying away, nest eggs would seem to be really of little or no use. But hens, as is well known; have a strong propensity to lay in each other's nests, and wherever there is an unoccupied nest with one or more eggs, there will the nest egg be laid. Therefore, where the hens have considerable range it is always well to place nest eggs in the nests. "We have knowi a hen to lay regularly in a nest with a nest egg in it, and then to forsake this nest wlien the nest egg was removed. But we believe that nest eggs have a further use. It is well known that in the case of wild birds, egg laying may be stimulated to a great extent by the presence of one egg and the removal of all the others. The high-holder, which usually lays but four eggs, may be thus stimulated to lay fifteen; why may not 
this principle hold good in the case of the common hen? We believe that it does, and our rule has been to have plenty of nests, eacls provided with a nest egg, and to remove all eggs, as fast as this can be done without disturbing the hens.

What shall we use for this purpose? Some poultry keepers use any old or stale eggs that may tre on hund-a very filthy and foolish habit, as such eggs when broken defile the nests and clisgust the hens. 'l'o disgust such owners by any amount of filth would of course be impossible. Some English writers recommend a sinall lump of chalk, and this is no doubt very good when chalk is easily procured, but, unfortunately, it was not available in my neighloölhoor. At first, therefore, we used the common white glass nest eggs, and during warm weather there can be no objection to such eggrs except on the score of cost. Dealers ask from three to six cents for them, and this is altogether too much to pay for best eggs, though perhaps glass ones cannot be sold for less. In cold weather; however, the hens seem to dislike them. 'Ihey easily become very cold, and being comparatively poor conductors of heat they are very chilly to the touch. Our little German maiden thought, therefore, that she would get up a better nest egg, and so she emptied a few shells of their contents and filled them ivith dry corn meal. This would have answered adnirably if the rats and mice had not soon found them out and destroyed them. Perhaps if sle had used sawdust the rats would hare let them alorie. But any kind of powder is bad, although the device was a very ingenious one. We were therefore driven to adopt another plan. We made a very small pinhole in one end of an egg, and in the other end we cut a hole three-eighths of an inch in cliameter. The contents were blown out of the egg through the large hole, and the shell was then filled with plaster-of-Paris properly mixed with water. As soou as the plaster hardened we had a most excellent nest egg at a cost of less than half a cent, for it must be borme in mind that the egg itself could be used for cooking purposes.

The plaster used for this puirpose may be obtained at any paint store. The proper waiy to mix it is as follows: Pour into a bowl as much water as you think you will need to fill the egg-shells you 
have prepared, and shake into it the powdered plaster until the whole is like good cream. It should be just thin enough to pour very easily. Before mixing the plaster, everything should be in readiness, as the mixture sets, or becomes quite stiff in a few minutes, and consequently it should be used as soon as mixel. 'Prepare the egg-shells by blowing them as we have describeil, and then paste a small piece of paper over the small hole. This should be doine long enougl beforehand, to allow the whole to dry. Place the eggs in a pan of sawdust, earth, sand or ashes, so that they will stand firmly with the large hole up. Then mix the plaster, and with a funnel, made of tin, or even of card, or stiff paper, fill all the eggs as quickly as possible. If the plaster is too thiu, it may shrink in the eggs, and leave a vacaucy at the top. Watch for this and keep filling up.

Afterwards, however, we adopted wooden nest eggs as being still better. Such nest 'eggs can be turned out of any soft wood for a few cents per hundred, and when dipjerl in whilewash and dried, they form the best nest eggs to be had. If first soaked in a strong solution of carbolic acid and then whitewashed and dried, they will effectually drive away all vermin from the nest.

Wooden nest eggs can be made by any wood turner out of the cheapest and lightest wood. Willow, chestnut, poplar, etc., are all good. An expert wood-turner can make three or four a minute, and any boy can turn up very good ones in the cheap little lathes that come with scroll saws. A few dozen nest eggs would be a nice Christmas present for any friend that has hens. The wooklen eggs should he dipjed in commoin lime whitewash, and allowed to dry. As often as they get dirty, souse them in a pail of whitewash, tumble them about with a stick and spreat them on the ground to diy, first laying down some old newspapers to keep them clean.

There is a small variety of gourd, the fruit of which is almost exactly the size and shape of all egg. Such little gourds make capital nest eggs, and they are now cultivated by some poultry keepers for that very purpose. 'They, too, may be cleaned by whitewash. 
We made it a rule to keep nice clean nest eggs in every nest, and the wooden eggs had this advantage, that they were so light, that, even in the dark, they could be readily distinguished from the real eggs. On one occasion, when we were using glass eggs, we were surprised at the enormous number of eggs reported as being laid by our half dozen hens-something like two to each hen-and our hired girl was in ecstasies. She had collected the whole contents of the nests-nest eggs and all! 


\section{Atarketing.}

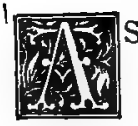

$\mathrm{S}$ the mild days of spring approached, eggs began ccme in quite rapidly-thirty and forty dozen per day-and it was necessary to find some methocl of getting rid of them profitably. I tried to sell all I could to private parties, and the rest $I$ was obliged to get rid of at the stores, though the price was at this season very low-even down to 18 cents per dozen. As I expected next year to have twice the number of hens in my yard, and to get more than twice the number of eggs, it was necessary to get up a system of marketing which would relieve me somewhat from the danger of glutting the stores, and I saw that this could only be done by offering extra ialucements in the way of freshness neatness and convenience to the consumer.

I had always had a great horror of " mildlemen" and "jobbers." As a general rule they are mere parasites on the body social, standing between the retailer and the producer, and fleecing both. I concluded, therefore, that I would have nothing to do with them. I found, however, that the "egg business" was in a most singular state. The retailer pail almost as much for his eggs as he got for them, and those large establishments (restaurants, hotels, etc.) offered prices a good deal less than the groceries pairl. At first I was puzzled over this condition of things, but I soon saw through it. The hotels and restaurants in our large cities never buy fresh-laid eggs. When I could get forty cents per dozen for eggs in the groceries, they offered twenty and twenty-five! What eggs could they buy at that price? Chiefly imported eggs, brought from Belgium, Denmark and Germany, where money is so scarce amongst the wretched inhabitants that their crops are sold for whatever they can get. No wonder that such eggs differ widely in flavor from what are called country eggs. I have always been suspicious of eggs in restaurants, but since my investigations, 
when I was trying to find a market for my own eggs, I have never touched an egg in a restaurant.

On the other hand, the grocers give the country people full value for eggs, because they expecterl to pay for them in trade, although, perhaps, such a condition was not always expressed. A country woman comes to the grocery with a few (lozen eggs; she sells them for money, it is true, but she turns right round and buys her tea, * coffee and sugar at the same place, and the bill for these probably exceeds the amount she receives for eggs. One who did not buy as largely as she clid in proportion to her sales could hardly be expected to meet with the same favor.

The marketing of the eggs was therefore a problem that gave me a good deal of anxiety. I finally resolved to work up a local trade, if possible, and secure regular customers, who would be supplied with my hest eggs, guaranteed to be not over two clays old. The following is the plan which I ultimately adopted, and am now carrying out. The first season our methods were of necessity rather slipshod and imperfect, and it is unnecessary to detail them.

I had a few boxes made, twenty to begin with, each holding three dozen eggs. As our eggs were quite large, the boxes were 8 inches long, 6 inches wicle, and 8 inches deep. They had a nice lid, and a wire handle or bale, which folded down over the box and out of the way when packed in the spring wagon. On the top of the lid was a label, a copy of which will be found on the following page, and in each crate we generally placed a few spare labels, loose, as circulars.

The price was given by writing it in the blank. When the price was changed a slip of paper was pasted over the old price, and the new price written thereon. 'I'his was some trouble, it is true, but I believe it paid in the end.

The following is a copy of the label: 


\section{FRESH EGGS}

FROM

\section{EERNIEBIELD POULTRY YARDS.}

Each egg is stamped with the dute on which. it was gathered, and is guaranteed to be not over two days old when delivered.

As these eggs have not been fertilized they will not hatch, and will therefore keep longer than ordinary egos.

- The utmost care has been taken to obtain the very best breeds. of forels, and to so feed them. that the eggs weril be of large size and of the finest flavor.

A tainted egg in our crates is simply an impossibility.

\section{ORDERS SOLICITED.}

Eggs suitable for hatching supplied on application. Postal cards addressed to

\section{J. P. HAIG}

\section{Ferniebield}

promptly attended to.

Prices according to the market rates. This week the trice per. dozen is .................................

I also had a neat little rublser stamp made, with the following inscription:

\section{EgGS FROM Ferniebield.}

$$
\text { Fan. } 5,18 \ldots
$$

The date was changeable, ancl with this stamp a boy could mark the eggs at the rate of about five per minute, or three and a half hours to $\mathrm{I}, \mathrm{Q00}$ eggs. 
At first the new system was the subject of a good deal of laughter and quiet ridicule. This very ridicule and laughter helped me, however. I weut to a number of the best families in town, and left a crate containing one dozen eggs, with the following note which I had manifolded on a gelatiu pad:

"I take the liberty of leaving with you a few eggs, the quality, etc.; of which you will find fully described on the enclosed circular. If, after trying these eggs, you are pleased with this method of absolutely insuring your table against the presence of a stale or tainted egg, I shall be pleased to receive your orders for any quantity, however large or however small. Please preserve the crate, which will be called for. Our system is to leave the crate with our customers, exchanging full for empty ones when we get orders. Trusting that you will pardon this intrusion, I remain, etc."

Now, when we lived in the village we were supplied with eggs by our milkman, a very honest, careful fellow. Yet with all his care it had sometimes happened that a stale egg would slip into the lot-obtained, I suppose, from some nest that har been overlooked. Under our system it was difficult for such nests to exist, and when we did find eggs in a stolen nest they were broken, cooked and fed to the chickens*. In this way we could absolutely insure our customers against stale eggs, and every one knows how a single stale egg will spoil the breakfast of a dozen people.

The idea took, as I thought it would. When we called for our crates we found in every one an order, of which the following may be taken as a sample:

"Having tried your eggs we like your system very much. Please bring us 3 dozen on Monday. MRs. J. Robinson."

* We knew that they could not hatch, and so it would have been a waste of gallinaceous time and effort to leave them with the hen. But hens that steal. their nests generally bring out strong clutches. We therefore placed in the nest a gitting of good eggs, and: we were always rewarded with a lot of fine strong chicks. 
At first these orders seemed a small business, and we were compelled to sell our surplus eggs at the stores, but we had faith that our customers would increase rafidly, and we were not disappointed. 'l'he novel mode of putting them up, the large size and excellent flavor of the eggs, and the fact that every egg was guaranteed, all combined to increase our business, especially als the prices were not higher than those asked by the best grocers. Eggs could be had much more cheaply than from me, but not fres/ eggs from respectable houses. The loose circulars were distributed freely as a novelty; postal cards began to come in, and visitors soon began to make their appearance at our yards to examine the poultry of which they had heard so much. My twenty crates were nowhere, and I at once gave an order for $25^{\circ}$. Before I received them I had orders for over three hundred clozen eggs, for which I had no crates. I therefore bought a lot of cheap but pretty little baskets, and here again the gelatin pad came to my rescue. I wrote a short explanation and apology for not sending a crate, and tied it to the handle of each basket.

$I$ made it a rule never to expose graaranteed eggs. in the stores. I sold eggs to the storekeepers, but unstamped or with the stamp washed off. For this reason I used a greyish kind of ink for stamping the eggs, and it was so prepared that a sponge and a little warm water obliterated the stamp completely. I never could quite remove the stain, and these stained eggs soon became known to buyers and were preferred-partly because they were larger and partly because they came from the now famous 'Ferniebield yards. And although an "egg is an egg," and large eggs and small ones sell for the same price, yet I found that most housekeepers had a decicled preference for large eggs, and that small ones would remain unsold long after the large ones had been bought up.

I sold eggs for hatching purposes too, and as it was known that I had very superior fowls, I had a good many orders. But this subject placed me in rather a difficult position. Everybody thouglit that the eggs from my laying hens would produce pullets as good as the mothers, and when I advised them. not to buy these eggs, they thought that my reason for so advising was that I did 
not want to sell-that I wanted to keep the breed to myself. When, therefore, they found that eggs which were fresh and certaiuly from my yards, could be had in the stores, they felt jubilant over the supposed fact that they had outwitted me. Remember that these people had not seen my labels and circulars. I liave since learned that quite a business was done in my eggs for hatching purposes. Incleed, I had several orders from grocers which I filled without hesitation, and it always puzzled me to know wlyy men should take a roundabout way of getting these eggs, when they could have come to me and got them without any trouble.

But alas! the eggs never hatched! And then it became current report that I applied a certain chemical to the eggs to prevent their hatching, and there was the proof in the curious stain found on each egg!! It is often in business as in lovers' walks; people prefer a crooked and rounclabout road to a straight one.

Some of my neighbors, however, took a different course. They came to me frankly, and said that they would like to get rid of their present stock of fowls, and get some from me if I would sell them eggs or fowls. I at once explained to them that my laying fowlsmy best hens for practical purposes, and those that gave the eggs which I furnished to my customers-were cross-bred birds, and that they could not keep up the breed, as a breed, but that I was perfectly willing to let them have eggs every year to keep their yards up. I also explained that these eggs actually cost me double what my marketable eggs cost; that I had to raise or buy specially fine cockerels every year, and keep the breeding pens carefully attended to. That my price for such eggs, eggs giving a first or second cross, was just double the market price, whatever that night be.

Some of them saw the reasonableness of the system, and bouglit eggs from me quite freely. Some tried to breed again from the birds thus raised, but it is needless to say that their flocks did not show the same uniformity and excellence that they did the first year, and every succeding year they became worse.

My sales of pure-bred fowls were very limited. To carry on a successful business in this branch, requires careful management, 
special plant and considerable advertising. I did not know enough about it to warrant me in going into it extensively, and besides that, I did not want to let anything interfere with my main experiment; but as I always had more pure-bred fowls and eggs than I wanted for my own use, I had no objection to selling the eggs at fair prices. I charged $\$ 2.00$ per setting for my choicest eggs, and as I always purchased a few choice breeding birds and raised a few first class cockerels every year, this price was not high. I always had in my yards cockerels that had cost \$ro; young birds from these certainly ought to have been worth $\$ 2.5^{\circ}$, which was my standard rate. And I readily got it, for Madame Rumour exaggerates everything, and it was soon bruited abroad that I was such a fool as to give $\$ 50$ or even $\$$ roo for a cock, and that whatever money. I had would soon be all gone at that rate. When the yards became a success, the word "fool" was left out, and I was called "an enterprising fellow" and a thorough judge of poultry, who was determined to have the best, even if it cost a hundred dollars. In all which the followers of her aforesaid Ladyship were greatly mistaken, but, nevertheless, it helped to sell my eggs and birds, so that I luave no special reason to complain, and have no intentionof suing anybody for slander or libel.

As soon as the crate system became fully known, I had orders for all the eggs I could produce, and none were lcft for sale in the groceries. By-and-bye, however, my production began to fall off, and this was the critical period in the business. It is true that, as production fell off the price was raised, and so the number used was slightly less. A crate which in the height of the season lasted but three days, now lasted four or five, but, even then; the demand did not fall off as rapilly as did the supply, for my customers were of a class that cared but little for a few cents more or less per dozen for eggs. If they chose eggs they had eggs, whatever might be the market price. Now, in failing to supply these customers, I ran great risk of losing them, for most of them had a ligh sense of their own importance, and indeed, I suppose some of them thought that if their support were withdrawn "Ferniebield would be sold at auction. I therefore prepared a circular explain- 
ing why I could not, at this time, always supply as many eggs as were wanted, but promising to divide, pro rata, with all my customers. I assured them that in quality and freshness there would be no falling off, and emled by suggesting that, while there could be no substitute for Ferniebiel, eggs for table purposes, others might perhaps be used to good advantage for baking, etc. 'This plain statement held all my customers, but I made a firm resolution that if I lived I would have eggs as plentiful in December as in April, and my progress towards that very desirable consummation has not been inconsiderable.

To save my customers as much trouble as possible, I procured a quantity of postal cards with my address printed thereon, and on the side appropriated to messages was an order in blank, as follows:

Deliver

dozen eggs on to

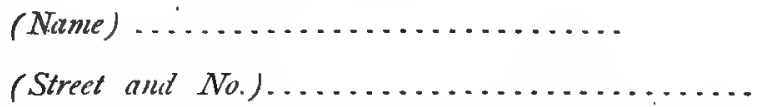

These cards were left with all our customers, so that if at any time they wanted egrss they could have them, and, as I had a box in the post office and always called there, eggs could be had every morning by simply leaving a card at the post office early enough. I never sent the wagon to town without a few extra crates to supply this casual demand.

The marketing of the surplus chickens gave but little trouble. For the prime table chickens, which we sold during the fall and winter, we fomml customers enough amongst those who bought our eggs. From some, we had regular orders to deliver one or two pairs of dressed chickens every week, on certain dalys, and it did not take many such orders to clean out our entire stock.

The old hens, we found it most profitable to sell in open market. 'They brought a certain rate per pound, and were pretty sure sale. We could not sell them to our regular customers as dressed chickens, and neither would we sell them to those who came to us wanting laying hens for a poultry yard, and stating 
exactly what they wanted. But, when sold in market, without any representations as to character or quality, we had no hesitation about taking the highest price we could get.

'lie stock that required the greatest care in selling, was our very early chickens. 'They were worth most-weight for weightsometimes bringing as high as seventy cents per pound. We found that there was considerable difference in the quality of these very early chickens, according to the kind of food given to them and the manner in which they were kept. We did not force ours as rapidly as some breeders did; we fed more cracked wheat and corn-particularly wheat-and less meal. The birds, therefore, showed firmer flesh, and did not waste as much in the process of cooking, and the flavor was higher. Our birds soon became known to the keepers of a few of the first class restaurants in the city, and we could always dispose of all we had at good prices. They were altogether the most profitable stock we raised, and after we got fairly under way and had our houses, coops and yards fixed up for them, they were not difficult to raise.

We sold a few of them in the village, but not many; Very few of the villagers-even those who were comparatively well to docared to give 75 cents for a little chicken weighing a pound and a half.

But, in the city, this price was not thought extravagant. Chickens heavier than a pound and a half clid not sell well, perhaps, because people suspected that they were simply old chickens of a small breed. We, therefore, tried to bring them to this weight as rapidly as possible, and as soon as we saw that they were large enough, we sold them out. We soon learned to estimate their weight, by the eye, quite accurately.

We found a great difference in the rapidity with which different breeds reached tliis size, and still greater differences in the appearances of the different breeds at this age. The great egg layersLeghorns, Hamburghs, etc.-llad to be kept too long; Brahmas, Cochins, etc., looked sprawley and skeleton-like; a cross between the two unatured rapidly and looked "splendid," as the little girls say. 


\section{$\mathfrak{b}_{\mathfrak{e r m i n} .}$}

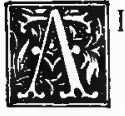

I.L cluring the summer and fall we never saw any parasites on our chickems, though perhaps this was because we did not look for them. One day, however, we were horrified to see a number of lice crawling over the eggs of a hen that had left her nest for feed. The hen had been set about the end of January, so that the weather was quite cold and the fowl did not seem to use the dust bath as freely as during warmer weather. When we caught the hen and examined her she presented a sorry sight; lice all over. What was to be done?

First of all, we put the hen in a barrel with a little fine straw, for the present, and placed ber in another building. 'The eggs were then removed from the nest one by one, wiped, and put in a clean basket. Fortunately we had another hen just ready to sit. She was carefully examined, no lice were found, and so we placed the eggs under her. The old nest, box and all, was then taken away, carried to an open place, dusted with sulphur and set on fire. When that fire died out there were no lice in that nest, and the slightly charred box was as good as new.

Our attention was next given to the hen. She was carefully dusted with insect powder and returned to the barrel, a fresh setting of eggs being placed under her. Next day she was again dusted, fed and placed in a clean barrel with clean straw. She was too weak to make much resistance to these changes, and settled down on the eggs very peaceably. The barrel in which she was first placed was carried out doors, the straw dusted with sulphur and set on fire. We had the most orthodox faith in purification by fire and brim. stone.*

\footnotetext{
* A recent writer expresses a doubt in regard to the efficacy of sulphur, but as he tells us to "put two or three pounds of brimstone or sulphir in an iron pot, in such a way as not to endanger the building; apply a match; shut it [the
} 
After the third dusting the hen seemed to be quite free from parasites, but still weak. We knew, however, that the powder would not injure the eggs of the vermin, and so in a few days we might expect a fresh brood. We therefore kept dusting and feeding plenty of nourishing and easily digested food-oat-meal mush, ment scraps, milk, etc. The hen throve, and we soon had the upper hand of the vermin. As, however, it would have been asking too much of her to sit double time, we gave her half a dozen chickens, and placed her eggs under a fresh hen. We now greased her with a mixture of lard and sulphur. This did not injure the little chickens, but might have injured the eggs. She was not troubled with parasites after that.

This incident taught us a lesson. After that we always examined our fowls with a special eye to lice. It is true that we rarely find them, but it is also true that hens are at all times liable to suffer from them if they get weak and unhealthy. They then neglect to take their dust bath regularly and thoroughly, and although I am no believer in spontaneous generation, yet $I$ an pretty sure that lice will make their appearance if the hens fall off in health and strength.

The hen that gave us so much trouble was a pure Light Brahma that had been recently bought, and in every case in whicli lice have made their appearance in my yards it has been in the case of fowls brought from other places. And I have found them on birds that I have obtained from dealers of high standing. With these men,

house?] closely, and let it burn slowly," we conclude that he has never tried it. Sulphur in large quantities cannot be set on flre by applying a match, as those who have used it for fumigating or bleaehing purposes know very well. 'The old bee-keepers ised to dip heavy paper or stout shavings in melted sulphur, and burn these, and this is a very good plan. Or the sulphur may be thrown on a small heap of shavings or straw, and when the latter is fired the sulphur will burn too. The plan adopted by bleachers is, however, the best and safest. Take a heavy iron vessel, the shallower the better, and put the sulphur in it. Heat this over a fire (ont of dool's, of course) until the sulphur melts and easily takes fire on the approach of a light. Then place the vessel in the house and let it burn. Sulphurous acid or the gas from burning sulphur is the most deadly agent known. Persian insect powder, carbolic acid, and other destroyers of the lower forms of life, are nowhere at all compared with it. It is the only thing that is relied upon by the National Boal'd of Health as a perfect destroyer of the germs of yellow lever, and if properly applied, no living thing - whether it be bird or beast, insect or disease germ-can possibly escape. But we must use enough of it, and the sulphur must be burned, not merely vaporized. 
however, space is a matter of great moment, and they are apt to keep their bircls confined in close quarters. And if lice once get a foothold under such conditions they are apt to spread. Whether or not it would be possible to absolutely stamp out lice from any yard I do not know. I have come very near it several times, so near that the most careful search failed to show a single parasite on any of the birls; but when colll weather came, and any of the birds failed to take their regular bath, lice would again appear.

The best remedy that I have found is insect powder, and where this is not handy, lard and sulphur may be used on laying hens, whose eggs are not to be hatched, as in this case there can be no objection to it. It is a general belief, however, that grease will prevent eggs from hatching. I have not tried it myself, and as there seems to be some doubt on the subject, I have not cared to risk it on valuable eggs. Major Cock, in his little book, published about 1843, tells us that he has "known eggs laid in Hamburg to be liatched in New Jersey, by covering them with lard and taking care not to handle them roughly." This is contrary to the general opinion. But for sitting hens the Persian insect powder answers admirably.

Mixing sulphur with the soft food given to fowls is also not only an excellent preventive of lice, but a capital tonic.

But the great means of preventing vermin is good health and plenty of dry earth for a dust bath. So long as fowls can roll in dry ashes or earth, lice cannot multiply.

There is but one kind of parasite on fowls, and this is peculiar to gallinaceous birds. It cannot thrive on other animals-not even on ducks or geese, far less on horses, cows or pigs. I have often heard it said that if poultry are kept in a stable the horses will get lousy. This is very likely to be the case, because any man who will keep his poultry in his stable is probably so slipshod that his horses will run down in health and so become lousy. But the lice from the hens will never remain on horses or cows. 


\section{Enemies.}

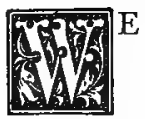

E lost but few chickens by disease, but the battle against winged and four-footed enemies was constant. Large hawks took off some of our best hens-hens that we thought were perfectly safe, on account of their size and strength. Cats would come miles to steal our little chickens, and weasels and skunks killed a few. But the greatest enemy was the common rat, and he was, also, the most difficult to circumvent, if we except certain bipeds who were evidently possessed of all the cunning and none of the honesty, that ouglit to distinguish humanity.

'The hawks were not very troublesome, that is to say, they did not kill many. We shot them without mercy, whenever we had a chance, but I must confess they clicl not always give us a good chance. As for traps on poles and all such contrivances, we found them perfectly useless, so far as these marauders were concerned, though we sometimes caught birds that we would rather have seen escape. I, therefore, had them all taken down and depended upon constant vigilance and a good breech-loader. I chose a breech-loader, because it could stand with the cartridges ready prepared and tied in a bag to the trigger guard, and thus be almost as ready as a loaded muzzle-loader, and the latter, when standing in a barn, is altogether too dangerous. I kept a muzzleloader at first, but, on one occasion, a carpenter, who was at work on the place, picked it up, discharged it through pure meddlesomeness and nearly killed a fellow workman. After that, I adopted the breech-loader. I generally used very heavy shot, so that we might be able to do execution at long ranges, and I studied carefully the rules for "loading so as to kill" laid down in a little work called "Shooting on the Wing," and found them admirable, so that the hawks and crows began to consider our 
locality rather unhealthy. Occasionally, when a hawk was seen sailing over the place at a great height, we fired a shot at him from a rifle, taking good care that the bullet went in a direction where it would do no lamage. We never succeeded in hitting a hawk in this way, but they did not seem to like the whiz of the bullet, and speedily took their departure for safer regions.

They did not seem to like to attack the poultry in the small breeding coops, probably taking the coops for some kind of trap. Amongst the large flocks we placed a few game cocks, and the hawks did not troulle us much after that.

Only on one occasion did the pole traps serve a good purpose. One morning in the fall we were awakened by a tremendous conmotion in the yard-dogs barking, ducks quacking, hens cackling, and all the signs of some terrible calamity. On looking out of the window I saw that one of our pole-traps had caught a large owl by the feet, and his cries and motions had attracted an immense number of crows, hawks, etc. Hastily doming a few garments, I seized my breech-loater and a belt of cartridges, and rushed down stairs. Getting quietly into the barn, I opened a narrow side door and commenced firing. At every shot $I$ brouglat down a hawk or a crow, and at first the firing did not seem to deter those that were left. Even after I lad picked off a hawk from within a few feet of the owl, tumbling him lhead over lheels to the ground, another would make a swoop, just as if nothing had happened. Of course, I tonk care not to shoot too close to the owl, and in a short time the ground was strewed with birds. Then they began to get wary. The crows were the first to abandon the fielcl, ancl after them the hawks went too. As it was, however, I lad a piece of rare sport, and revenged myself on enemies that, otherwise, I never could have reached.

I have heard it said, by old poultry keepers, that hawks will not attack poultry, if there are guinea hens around. I know nothing of the accuracy of this statement, but it certainly is "important if true."

Against most four-footed vermin, including cats, we found that a good Scotch terrier was the best defence. We had cats of our 
own, and they were never injured, neither did they attack the little chickens, but strange cats generally came to a speedy, end at the hands, or, rather, the teeth, of our dogs. And it was curious to notice how thoroughly acquainted the dogs and fowls became. If a strange dog came into the yards, there was a commotion at once, and all the hens were up in arms, but our own dogs might go about amongst the flocks, and quite close to a hen and her brood and never disturb them. Weasels and skunks were not very common. The latter is said to be a very useful insectivorous animal, but it is out of place in a poultry yard. It kills clickens, and should, therefore, be killed. When we had any indication that a skunk was around (and our noses were a pretty good indication of such an occurrence) a little vigilance and a charge of snipe shot generally prevented all damage.

But, for all four-footed creatures, the best preventive is a good trap. The trap must, of course, take them alive, or it will be liable to destroy some of the animals belonging to the place, and it must be large enough to catch a small clog, and sufficiently sensitive to be sprung by a weasel. I, therefore, had four large box traps made, and took great pains with the tables and triggers, making the latter myself out of fine tempered steel. These traps were distributed about the place, baited with a little meat. At first we caught our own dogs and cats, but they soon learned to give the traps a wide berth; the hens were not so easily taught, and would persist in being caught, when the traps were set during the day. We, therefore, set them only at night, and in them we caught; strange dogs, cats, rats, weasels, squirrels and snakes, but never a skunk.

But although we occasionally caught a rat in this way, these rodents were too cunning to be caught in any numbers in such a contrivance. And as poison was out of the question, we found it very difficult to guard against their depredations. Of course the dogs did a great deal to protect the chickens, but they could not be everywhere, and at night the rats would actually take the young chickens from under the mother's wings. We felt ready to adopt any remedy, however cruel. In fact, no one can look at the mean, 
cruel, cunning and ferocious face of a. rat and hesitate about destroying him by any possible means. 'The loss of an occasional chicken would always rouse up my ire, and after such occasions I woukl vow vengeance against the whole race. A few would be shot; one or two would be trapjeel; but the work was too slow and uncertain, and we would fall hack upon the dogs and cats. Finally the rats increased to such an extent, and became so bold, that one night they carried off an entire brood of my most valuable chickens. I thought, then, that it was time to do something.

I then built a small house, 8 feet square and 6 feet high, with just enough roof to shed the rain. It wals made of inch stuff, and had a door but no windows. 'There was a good floor, covered with old tun roofing that I got for almost nothing. 'The tin was carried about six inches up the siıles.

This house was filied wilh straw, in which was placed some wheat, corn, etc., and a handful or two of meal was also scattered over the straw. On every side was a hole 3 inches in diameter, which entered just above the tin. Four men could easily move this house to any part of the grounds. The first night we placed it near the coops in which the young chickens were kept and awaited results. 'The rats soon found it out, and, as we covild easily see by their tracks, male it their home. A remorseless war was then carried on against them in every other part of the premises. Tobacco smoke was blown into their holes; their breeding places were disturbed; their runs were filled with broken glass, and life made as uncomfortable for them as possible in every place except "Rat Castle." 'There they were left in peace and quietuess. At the end of a week, however, we went over the ground again, and drove topacco smoke into every hole we could find. This was done by means of a piece of rublere hose and one of the most powerful "smokers" used by bee-kcepers. With one of these smokers and a few feet of rubber tubing we could, in a few minutes, fill all the space between the floor and the ground, and between the wall and the lathing of any building, and drive the smoke out at holes twenty feet away. 'The effect of this tobacco smoke was most surprising. We know of no animal that can stand it. 
The rats and mice left the premises on the double quick, and many of them fell a prey to the dogs and cats that were on the watch, keenly enjoying the fun. But no tobacco smoke had ever been allowed to profane "Rat Castle," and thither they all ran. We could hear them figlting and squealing inside, and when we got through with the other buildings we just closed the four little doors of the house and they were all prisoners. Then we changed our tactics. Instead of tobacco we used sulphur, and by means of a simple furnace, made out of an old pot, with a wooden cover, and using our "smoker" as a bellows, we soon filled the little house with sulphurous acid-a most deadly gas. Being determined to make thorough work of it, we blew in gas at the bottom until it passed out in a steady stream at the top. We then closed every opening up tightly, and left the house till next morning. When we opened the house next day we found one hundred and fiftyseven rats in it-every one dead!! I thought, then, that this piece of work paid me for the expense and trouble of the house, etc. It was nearly a year before another rat was seen about the premises, and we have never been badly troubled with "them since.

The reason for building the holise was this: If I had killed the rats in their holes and runways in the barns and outhouses, which I might perhaps have done by means of sulphurous acid gas, they would have putrefied where we could not get at them, and this would have been insufferable. On the other hand, if we had driven them out with tobacco, and had not provided a retreat for them, we might have killed a few, but the greater part would have escaped only to return after a little while. The plan that I adopted obviated both these difficulties.

My reasons for covering the floor and a few inches of the sides with tin was this: A rat will never gnaw his way out into the light; but if the floor had been left unprotected they would have cut their way down, and would have burrowed in the ground and underneath the floor. When the final act in the tragedy came these rats might have escaped. As it was, we made a clean sweep, and destroyed or drove away every one. One hundred and fifty-seven rats make quite a pile. What could we do with them? Bury 
them? That would be waste. We passed them through our meat chopper and cut them up, bones, meat, hair and all. Since rats are the great trichina-carriers, it would have been dangerous to feed this meat to Vlogs, cats or pigs, but to fowls it is perfectly harmless. But to make sure, we boiled it thoroughly in our large pot, exposing it in four lots to a boiling temperature for four hours. At the end of that time every trichina, if there were any present, must have been as dead as the rats themselves, so we just made the soup into mush with a little com meal and fed it to the chickens. The rats load eaten our chickens, and now the chickens ate the rats-a just retribution.

As we have already stated, from that day to this we have never been troubled with rats, and the "rat-house," as we call it, serves very well occasionally for an extra coop; of late, however, we have been told that one or two rats have been seen about the place. If they get troublesome we will set "Rat Castle" in operation again.

When it is necessary to use poison instead of other means, great care should be exercised in the selection of the kind of poison, and in the methods of using it. Arsenic, whether in the ordinary form of "white arsenic," or in the various patent mixtures that are sold, such as "Rough on Rats," should never be used. "The reason is very simple and obvious: Arsenic, no matter into what combination or form it may pass, is always poisonous. A rat or a mouse poisoned with arsenic will, if eaten by a cat, dog or chicken, still act as virulently as ever, and cause sickness or death. There is another poison, however-phosphorus-which loses its poisonous qualities when it becomes oxidizecl, and hence is far safer. Phosphorns is poisonous only in the pure state; when in combination it is generally harmless, ancl frequently very wholesome. There is as much phosphorus in a pound of bones as would poison a whole flock of chickens, but when fed in the form of bone or phosphate of lime, it is quite the reverse of hurtful. Indeed, when bones are properly dissolvecl they form one of the most pleasant and wholesone drinks for human beings, as is seen in Horsford's Acid Phosplates, so gener ally used.

Now, when phosphorus is eaten by an animal it soon becomes 
oxidized and rendered harmless, but when arsenic is so eaten it never loses its virulent character.* Phosphorus paste, properly prepared for poisoning vermin, is sold by most chemists, and the recipe for preparing it may be found in any good book of receipts.

* An account of the dffferent poisons, and the proper antidotes for them, when accidentally swallowed by human beings, or by the lower animals, will be found in "What to Do in Case of Accident." The book is issued by the same house that publishes this volume. 


\section{Earln Thickens and figh-priced $\mathbb{E}^{\mathfrak{g} g g}$.}

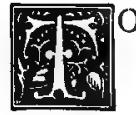

get in December those eggs that are usually laid in May, is one of the oldest problems in the "Chicken Business." If we could only get the hens to accommodate us in this respect, the making of a fortine would be an easy thing. But out of every $\mathrm{I}, 000$ eggs that are produced during the year by an ordinary flock, it will be found that

\begin{tabular}{|c|c|c|c|c|}
\hline $\begin{array}{l}45 \\
5^{6}\end{array}$ & $\begin{array}{c}\text { are } \\
\text { “ }\end{array}$ & $\underset{\text { produced }}{\text { pro }}$ & in & $\begin{array}{l}\text { January. } \\
\text { February. }\end{array}$ \\
\hline 132 & " & " & "6 & March. \\
\hline 176 & " & $"$ & " & April. \\
\hline I 50 & " & " & “ & May. \\
\hline 96 & " & “ & “ & June. \\
\hline 87 & " & "6 & " & July. \\
\hline 54 & " & " & " & August. \\
\hline 83 & " & " & " & September. \\
\hline 84 & $"$ & “ & “ & October. \\
\hline 26 & " & “ & “ & November, \\
\hline I I & “ & " & “ & December. \\
\hline
\end{tabular}

Consequently, while eggs bring 50 cents per dozen in December, they fall in price to $r 8$ to 20 cents in May. What can be done to effect a change in this respect?

At first sight, it would seem that the arlvent of cold weather is the chief cause of the stoppage in the production of eggs, and to test this, Reaumur kept his hens in artificially warmed houses and tried in this way to get eggs in winter. But he failed. We might have expected this when we observe that one of the coldest months, March, is also one of the most prolific. Others have hoped by stimulating food to make the hens keep up egg-laying. We liave 
tried it, and met with a small measure of success, but food alone will not accomplish a great deal.

Others, again, depend upon the breed. It is well known that some breeds-Leghorus, Hamburghs, etc.-are known as summer layers, while the Asiatic forvls-Brahmas, Cochins, etc--are winter layers. 'There is i good deal in this, but not enough to turn the tables.

Others try to get eggs in winter, by raising very early chickens, and this is the most efficient method of all, provided other conditions are favorable.

The fact is, that it is useless to depend upon any one or two of these conditions; we must bring them all into play if we would have eggs in winter. We must have hens of a suitable breed; they must be properly housed and fed, and they. must be of the proper age. A failure in any one of these conditions will be fatal to success. These three things are like food, clothing and air to a human being: No amount of elothing will make up for want of food, and no amount of food will enable us to do without air. We must have all three together if we would keep in good health.

As regards the best breed, I had long ago made up my mind that a cross between the Hamburgh or Leghorn and some heavy Asiatic fowl was altogether the most promising in this respect, and in making up my breeding coops, I had this in view, though not quite as clearly as I would have done, if at that time I had had more experience. When I came to fairly face the problem of producing eggs in December, I mated White Leghorn and Spangled Hamburgh cocks with goor heus having a large proportion of Asiatic blool. Some of the latter were pure Brahrna, others were apparently Cochin crossed with Dominiques, and I fould that I got better results from these crosses than from any other breel.

Raising clickens in January is troublesome work, and unless the poultry breeder has good facilities and considerable experience, the outgo will exceed the income. Of this I was well assured, but I resolved to try the experiment: 
There were plenty of heus wanting to sit. After their summer crials and autumn laying they hild stopped prorlucing eggs, and wanted to take the next step in hen-life. So we cleaned out the rooms that we had formerly usel for hatching, and packed into it is many nest-boxes as it would hold. We succeeded in placing 12 boxes, containing $4^{8}$ hens, lut as the weather was cold, we gave each hen only to eggs, making 480 in all. This was not quite enough, so I placed ro more boxes in clifferent parts of the stable, and filled them all with hens. With these 40 hens we expected to have some trouble, but we thought, that, as they did not have much temptation to run about at this time of the year, we might be able to control them.

It was during the progress of this experiment that I found out the mistake I had made in not taking better care of my breeding luens, so I was obliged to take such eggs as I could get. By making temporary arrangements with greenhouse sash, and by selecting some of the best laying hens from the general flock, and putting them with suitable cocks, I managed to secure eggs enough to gradually fill all the nests; but of course the hens were not all set at the same time, and some of them load been brooding for some time before they were set. The latter circumstance was unfortunate, as hens that have brooded for some time before eggs are placed under them are apt to leave their broods too soon. Our success in managing the sitting hens was, however, very fair. They were atiended to every morning; fed and watered, and then shut up until sext morning. We had three lots which had to be let out at clifferent times; the chickens of the first lot was due the first week in February; those of the second lot during the second week, and those of the third lot during the third week. It made no difference whether the hens of the same lots returned to the same nests or not, but it was important not to mix the lots. We had very little trouble, however. It took about two hours to two hours and a nalf every morning to attend to the sitting hens, but all this time was not occupied. After the hens had been driven into the outer room, the doors of the latter were locked, and the attendant had a good half hour to devote to other wark while the hens took -their 
food and drink, and dusted themselves in the dry earth and ashes. provided for them.

Our first little chicks found themselves in a "cold, cold world" when they burst their shells. But the old heus kept them warm, and during the first thirty-six hours they were kept shut up under their mothers, the only attention that the hens got being the removal of the empty shells. At this time of the year one of the greatest mistakes that can be made is to get the chicks out of the nest too soon. They need warmtls and rest, rather than food and exercise, for when they leave the shell they have just had a full feed of the richest food, and, as any one can see, nature did not intend that they should run about immediately after leaving the shell. Partridges and some other birds do this, but chickens never. We have lost many chickens by meddling with them too soon; never a one by letting it alone. On the second day, however, we took the hens off the nest, placed the chicks on the floor, and offered them cracked wheat and warm milk. The latter they drank quite greedily, and the wheat they soon learned to pick up. After they had been fed they were returned to the old nest for the present.

The weather at this time was very cold-occasionally down to zero-and it was hard work to keep the little things warm. We had 88 hens sitting; these would probably produce 600 chickens, and I intended to give each hen ro chickens, so that 60 brooding coops would be needect. I fornd that the coops we had used during the fall would take up too much room, and, as they would require a house to cover them, I might as well divide the house itself up into coops. Having all this in view, I had put up a rough board shed, 40 feet long and io feet wide. It was just high enough to allow one to pass easily up the middle. The roof was of matched boards, except where six greenhouse sash were inserted to admit light. The floor was divided off as follows: A walk 16 inches wide was left through the middle, and the spaces on each side were divided into 30 compartments each, making 60 in all. The divisions were simply boards $\mathrm{I}_{4}$ inches high, and the compartments were covered with wire netting of 1 -inch mesh. Four stout stakes were driven into the floor at the end of each di- 
vicling board and next the middle passage. These stakes held the dividing boards in place, and the end boards stood between them and could be. easily lifted out; in fact, they formed doors to the compartments. To keep the house warm I banked it up with leaves, which were kept in place by brush, and I put in an old cook stove with a lot of old pipe which ran the entire length of the building. This kept out frost, even in very cold weather. At night the sashes were covered with old matting.

As soon, therefore, as we had a few clutches out we arranged this brooding house, started the fire, 'and got it well warmed up. In this we were aided by a few days of bright sunshine, so that when, one afterwoon, we put ten bens with their chicks, amounting to roo in all, in ten of the compartments, they' seemed to be cnjoying a summer atmospliere. The broods now began to come out very rapiclly, and we soon had one sicle of the house full.

'The care of these chickens involved a good deal of labor. It is true that it was not labor of a very hard kind, nor did it require a great deal of intelligence to follow the rules which I laid down. We had very few sick chickens; indeed, we lost more by accidents than by sickness. To give an historical account of our method of management would occupy too much space, but the following will be enough to guide the intelligent reader.

The great points in rearing early chickens are suitable food and warmtl.. The latter condition involves dryness as a special feature; animals that are kept dry can resist a good deal of colk, but if once the feathers get wet and matted the bird becomes cold and chilled, and it does not take much to cliill the Jife out of a young chicken. To keep the chickens dry we found to be one of our most difficult tasks. If a saucer of milk or water was placed in the coop for them to drink they were sure to get into it, and the hen would upset it and make the whole compartment wet and uncomfortable. The poultry stores keep on hand fountains like large bird fountains,

- by which this difficulty may be in a measure avoided, but these fountains are too expensive, are difficult to clean, and where milk is used they require too much to fill them. So for milk I used saucers, which I protected with a netting of wire; tor water I used 
large soup plates, in whici I placed an inverted bowl filled with water. The howl was first filled with water, the plate placed on the top, and the whole quickly turned. over. The water was now retained in the bowl by atmospheric pressure, and gradually descended as the chickens consumed it. 'To get sufficient depth of water in the plates I chipped a piece out of the edge of each bowl.

When milk was used, and we had not a wire protector for the saucer, we simply inverted a small bowl and placed it mouth down in the latter.

The food that we used during cola weatler, was plain, but nutritious. For the first day or two, cracked whent given dry (see page I4 ), and milk to drink. Then, in the mornings, they had a mixture of bran, corn meal and ground oil-cake. The oil meal was thoroughly scalcled with boiling water, and allowed to stand some time, when it formed a thickish soup. This was then worked into a stiff dough with a mixture of equal parts of bran and corn meal, and fed to the chickens in small lumps. This mixture we found to be exceedingly nutritious. As the chickens had no access to gravel, I had a small quantity washed and sifted, and we kept a little wooden tray full of this material constantly before them. 'They seemed to enjoy picking it.

Every day we gave them a very little meat and some finely chopped cabbage. For both they were very greedy. Cracked wheat we kept before them all the time. We preferred it to corn, though it cost a little more. On this feed they kept in good health and grew rapiclly.

One of the greatest difficulties in the care of chickens is the 'watching of individuals. It is inpossible to give attention to each single bird; they are attended to in small flocks, and an inclividual of this flock may get quite sick before even a very faithful attendant notices it. Still, by watchfulness, a good deal was accomplished, in this direction, and we kept two or three old and very motherly hens for the express purpose of taking care of weak and sickly chickens. About half of those that we transferred to these hens came through all right. When a clircken is very sick, the most profitable and merciful course is to kill it at once. 
The plans that I have described gave us better results than 1 had ever had before with chickens in winter. It is true, that, previously, I baul only raised a few clutches, mcre for experiment than 'anything else, as it does not pay to fuss with one brood of chickens in winter. It is just as easy and far more profitable to attend to a hundred.

Out of 880 eggs, we hatched 637 chickens and of these we brought $5+3$ to maturity. In April and May they were worth 75 cents to $\$ 1.00$ per pair, making, at least, $\$ 25^{\circ}$. The food had cost very little, but as it had been taken from the general stock, I am unable to give the exact figures.

We sold the cockerels and the culls of the pullets, and this paid for all labor and expenses, and left a handsome profit. We had I50 very fine pullets left, and they supplied us with many eggs during the following wister.

'The success of this experiment led me to repeat it the same season. As soon as the heus.were all off the nests, we had the hatching room thoroughly cleaned, fresh dry earth put down, new nests, etc. 'I'hen, calculating the time when our brooding house would be vacant, which we placed about April ist, we filled the boxes again witl sitting hens. If we had had sufficient brooding room, we could easily have brought out three or four sets of broods from our hatching house, but as it was, we could only manage two during the very cold weather. But this was enough to show the profitable character of the system, and next season I tore down the temporary structure that had served us during the first winter, and put up a cheap but substantial house. 


\section{Retrospective.—profit and Loss.}

TS The been said by high authority, that in Agriculture, he who buys 5 per cent. too high and sells 5 per cent, too low, loses his entire profit. If this be true, it shows that ahe profits in most agricultural pursuits are not as large as some would have us believe, and indeed, it is the opinion of those who are best informed on the subject, that the wealth of our furmers does not come from profits arising after the manner of those from mercantile transactions or contractors' undertakings, but is simply the wages of labor, close economy having been exercised in disposing of it. And so, I found that a good share of the outcome of my poultry yard was due to me as wages for the labor I had performecl. When, therefore, about the first of the year, I began to calculate where I stood, I was a little surpirised at the extent of my investment, and at the very considerable part which was due to the labor of my own hands, for I had far exceeded the proportion of my own time which I had first allotted to the enterprise, and insteal of half time, as I had at first calculated, I found that I had given to it pretty long hours.

While my begimning had actually been made in June, the first season had really closed with December, so far as that year's stock was concerned, so that when early in January I turned my attention to the hatching of new broods, I felt that I was entering upon another season's work, and was really commencing a new year in the poultry yard as well as in the calendar. But since it was the yearly results that interested me most, and as my experiment commenced in June, I have regarded the years as beginning in that month.

The first season I regarded more as a sort of apprenticeship, than as a fair sample of what the business would be, but on examining the accounts, and allowing a fair value for stock and per- 
manent plant, I felt that I had not lost anything. It is in the valuation of the stock and plant, however, that the fallacy of most statenents in regard to financial undertakings lies concealed. If we only have the opportunity to acljust this feature, it is easy to show a good balance sheet, and this may perhaps be one reason for the prevalent tendency to "water" stocks. If the stock of any enterprise has cloubled in amount, it would seem to the unsophisticated, that the property has actually doubled in value while in fact it may have depreciated. A very slight addition to the valuation of each of 3,000 chickens would change the balance from the loss side to that of profit, and this is easily done on paper.

In the preceding pages, I have given my plans, methods and many of the ultimate results. To give a minute detail of all the haps and mishaps would swell this work into a large volume, and I will, therefore, merely offer a summary of my progress each season, and give the balance sheet of the third year, at which time I had my yards and system fully under way.

Ou the last day of December of my first year, I found that I had more than half the number of hens that I had set out to keep, and in addition, I had a great many birds that might be converted into casly as soon as the spring came. It was not, therefore, a difficult matter to make the number up to 1,000 first class hems during the next six months. $\mathrm{My}$ earliest hatches of the following season gave me I $5^{\circ}$ good pullets; from my second hatch, at the end of March, I had 213, so that I needed only about 150 more to complete,my quota. 'These were raised in May without any special effort, so that when the roth of June came again, I had r,ooo good bircls, though, of course, one half of them were quite young. Besides these, I had a large number of cockerels and culls, which could be disposed of in the fall.

'I'be supply of eggs usually begins to fall off towards the end of May and the first of June, but my fall-reared pullets were now in the full tide of egg-laying, and as I was now just commencing my new system of crate-delivery, this came very opportunely.

Although the supply of fresh-laid eggs undoubtedly diminishes 
after May, the price does not rise very rapidly. This is probably owing to the fact that the demand falls off somewhat during the early summer months, but after a time the jorice adapts itself to the supply, and it was to meet this state of things that I depended upon my fall broods.

During the spring, I sold off all the old fowls and all the culls, reducing my stock very considerably, and making room for the young pullets. 'These I endeavored to colonize in lots having special characteristics-each lot being placed in its own house, so that a record might be kept of the results derived from it. 'Thus in one house and yard we kejt pullets which were a cross of White Leghorn and Light Brahma, and of a certain age, and no other birds of a different kind and age were admitted to this yard. 'This made the numbers in the different houses vary, it is true, but it enabled us to get the real average results from the different breeds and crosses, and this was what I wanted.

Early in the second season, I erected enough houses to make up seventeen, besides the old house and the breeding coops. 'The litter were all brought together and a glass shed erected in front of them. This shed was divided into as many compartments as there were coops, and the yards radiated in a fanshaped form, from the coops as a centre. In this way the coops and sheds sheltered each other, so that the hens were kept comfortable, and many of them kept on laying well on into the winter. But with all my efforts, I found it impossible to get enough eggs of the second cross to supply my needs for my very early hatches, aucl so I was obliged to use those of the third cross. But by using a thoroughbred male of a different strain, I succeeded very well. 'The amount of eggs to be had from these breeding coops, however, is merely a question of management, and after the second season I was not troubled on this score. And since I obtained a good strain of the Plymouth Rocks, I have had no trouble at ali. The Plymouth Rocks are comparatively a new race, and have not a great deal of potency. 'The luens, mated with vigorous White Leghorn cocks, give remarkably fine results, and we are always able to get as many early clickens of this cross as we need. 
Some of the early lhatched pullets began to lay in September, and they were all laying by October, so my supply of eggs kept up very well into the winter. I placed ${ }_{25}$ of these pullets in the old house, which was kept warm by the fire used to heat the large kettle. For the purpose of testing the possibility of keeping these pullets laying during the winter, we gave them the utmost care and atteution, and they repail us very well. So that by the end of the second December I had attined the object at which I had aimed, and not only had my $\mathrm{r}, 000$ hens, but had found that they actually yielcled me a profit, as against interest, labor and food. 'The profit may have been small, but still it was on the right sicle of the ledger, and the extent of it was a mere question of judicious management.

Ths third January came with brighter prospects, as we had greater experience, more skill, and better facilities. Our hens of the fall broods, and even some of the very early luatches of the preceding January ceased laying and showed a disposition to sit, and this was also the case with many of our choice breeders. So we got our hatching room and brooding house in order, and prepared to raise a goodly lot of little chicks. In this we succeeded without difficulty; the hands knew just what to do, and under my supervision it was thorougbly done. I found it no "half-day's" work, however, but that full time was demanded. There is no eighthour law in the chicken business.

It was this season that I regarcled as the test of the sounilness of my plans and of the possibility of actual success. Fortunately for me real estate had again improved in value, and I found that if my scheme for ekeing out my income proved a failure I could at least dispose of the place without loss, and curtail expenses by moving into a snaller house. During this season, therefore, I kept very careful and accurate accounts of all expenditures and receipts, and the following is the balance sheet of this season: 


\section{EXPENSES.}

Interest on cost of buildings, plant and stock fowls........ \$120.00

Labor Account-1 woman at $\$ 15.00$ per mouth and board... $\quad 310.00$

1 boy at $\$ 2.00$ per week and board......... 200.00

Man-half time...................... $\quad 250.00$

Food-900 bushels of corn at 56 cts................... $\quad 504.00$

800 bushels wheat at 87 ets..................... $\quad 696.00$

2,000 lbs. oil cake meal........................... $\quad 37.50$

2,000 lbs. cor'u meal at $\$ 1,25 \ldots \ldots \ldots \ldots \ldots \ldots \ldots \ldots . \quad 25.00$

2,000 ltss. wheat bran at $\$ 1.10$ per $100 . \ldots \ldots . . . . . . . . \quad 22.00$

3,000 calbuges. ................................... $\quad 126.00$

Meat, bones, calves, etc....................... $\quad 57.00$

Fuel.......................................... $\quad 15.65$

$\$ 2,363.15$

RECEIPTS.

Eggs, 116,197 or 9,683 doz.............................. \$2,557.48

"Broilers ".............................................. $\quad 383.75$

"Fowls" - or old hens................................ 287.25

Cockerels and inferior pullets.......................... $\quad \mathbf{4 7 3 . 7 5}$

Pure bred cockerels.................................. $\quad \mathbf{2 7 . 5 0}$

Egfys of thoroughbreds.............................. $\quad 123.50$

$\$ 3,853.23$

Expenses as above.............................. 2,363.15

Profit. .................................. $\$ 1,490.08$

At the close of the year (June roth) I harl r, 126 hens in the laying yards; 439 young pullets, and between 700 and 800 young chickens. The old hens and the "broilers" had all been solil off, thus reducing my stock to a minimum, and consequently making the feed bills of the year appear quite large in proportion to the actual number of birls on liand. But it must also be borne in mind that the food here charged had reared and fattened the cockerels of the previous fall. 'Ilue prices of both the whent and corn are very considerably less than the market rates, simply because I happened to procure a considerable quantity of both in a slightly damaged state, but perfectly good for chickens.

In addition to the food charged in the bill as such, however, there was a considerable quantity which was really represented in the labor account. Thus we had about izo bushels of corn of our own raising, besides milk, potatoes, turnips, clover, grass, some 
sum-flowers, etc., etc., and the chickens picked up during the year a great deal of food in the shape of seeds, insects, worms, etc., off the cultivated.land. None of this could be taken into the account, and yet it was all of importance, but it is very obvious that whatever it cost is fully represented in the charges for labor and interest.

It was amusing to notice the eagerness with which the chickens followed the plow, especially in grass land newly broken up. Such land woull be full of the larvæ and pupæ of cock-chafers or Maybugs, and the way the chickens, old and young, feasted on them was gratifying on two accounts: The chickens were fed and the insects were clestroyed.

'I 'he first year we were on the place the cow had a very beautiful heifer calf, which we raised. 'This calf was now a cow in full milk, and consequently our supply from the two cows was considerable, though none too much. We churned all the milk except the small quantity used in the house, and fed the buttermilk to the young chickens. It paid better than selling the fresh milk at market rates. 'l'his was an important item, but is fully covered by the cliarges for labor and interest. Whiie the feed bill may appear heavy, the labor account probably appears light, for in addition to the hands named in the statement there was my own labor, which amounted to fully as much as that of any man that I could have hired, and the house girl gave us a great deal of assistance in preparing food and in other ways. And perhaps I have underestimated the amount of work demanded from the man, though, as I woukl have had to have him anyway, his wages might be fairly left out altogether so far as my particular olject was concerned. But in a thoroughily organized poultry establishment, run as a special business, his whole time would have to be charged to the poultry.

'The same is perhaps true in regard to the horse. Her keep and expense of shoeing, harness, wagon reprairs, etc., would all have to be charged to the expense account, if poultry were the sole source of income; but as it was, I obtained nearly $\$ \mathrm{r}, 500$ per year that I "would not otherwise have had, and this so turned the balance in favor of Ferniebield as a residence, that $I$ have no present intention of leaving it. 


\section{Canclusian.}

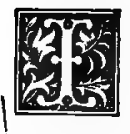

HAVE now given the reader a history of my methods failures and successes, and $I$ have endeavored to answer practically the question: Can a living be made from poultry alone, the entire dependeince being upon eggs and fowls sold at ordinary market rates? My experience tells me that it can be done by any one that has the capital, inclustry and knowleslge that are needed. The market for eggs and table fowls is always good; better sometimes than others, but still always remunerative. Stocks may go up or down; banks may break and business men may fail; bur old Mother Earth always pays her dividends promptly. Aud the amount of business clone in eggs and poultry is so large-over $\$ 265,000$, 000 per annum-that there is no dainger of the business being over(one. Ten thousand new poultry farms could not perceptibly affect the market.

If reasonable care betaken, there need be no diuger of disease carrying off our flocks and ruining our prospects, and we know of no other accilent that can, greatly imperil our success. But there are certain points upon which we must insist, or failure will be certiun.

In the: first"place, the individual must be adapted to the business. It is no child's play to take proper care of a thousand fowls, and if that number is cloubled or trebled very good executive ability will be needed. The care of a small flock may prove a profitable and pleasant pastime for invalids and laclies who have no employment, but, unfortunately, a small flock will not yield the owner a living, and a large flock will require not.only the care, but the labor of a strong man, and of one who is not afraid of exposure to storms and cold. Do what you will, there will be times when sudden storms will overtake some of your poultry, and if you are too delicate to take care of them, good-by to profit.

But industry, strength and hardihood are not the only requirements. Many a man, who bears amongst his neighbors the reputation of a Job for patience, will fail when he attempts to tackle an old hen that persists in sitting where she is not wanted. Kindness, 
patience and thoughtfulness are qualities which cannot be alisponsed with. And, noreover, the successful poultry keeper must have a taste for the business and a foudness for animals. If his duties are performed as a mere matter of duty, and not con amore, we would not give much for his chances.

'The next requirement is abundant capital. In a book published a year or two ago, in which various occupations are described and recommended as suitable for women, the writer names $\$ 300$ as the amount of capital required for a poultry establishment! 'Three hundrerl dollars would no doubt set up a very nice poultry yard for some one who got her living from other sources, but we venture to say that if any woman, having $\$ 300$, puts that amount into poultry, and depends upon them for a living, she will fail. My experience tells me that $\$ 3,000$ is nearer what is required, and with less than this at command success cannot be attained. We assume, of course, that the person who undertakes the business intends to make a living out of it, in which case he will have to give his whole time to it, and consequently will have to get his support out of it (or out of his capital) from the start. Less than $x, 000$ hens would not give even a noderate living, and they alone would be worth $\$ 1,000$. It is true that hens maly be bought in market for much less, but we speak of that we know when we say that 1,000 such hens will not yield a living to their owner. The hens must be select bircls, and are most cheaply and satisfactorily raised by the poultry keeper himself.

A thousind hens cannot be housed properly for less than \$1.0o eaclr. Unless properly housed the results will be on the wrong side of the ledger. 'Thi $i$, therefore, requires another $\$ \mathrm{I}, 000$.

Food must be bought by the car load, not by the bushel, and cash must be pail for everything. Any other system will so cut down the profits that the result will be anything but satisfactory.

To do this needs a zeorking capital as large as that named by the writer referred to. Now, if to the requirements we have named we add the cost of living until the returns come in freely, the rent of the land and the cost of improving the same, it will be seen that our demand for $\$ 3,000$ is not by any means extravagant. 
I am aware, of course, that with persons who already have some other business, and merely wish to work gradually into poultry keeping the case is different. Such a person might begin with roo. fowls, and by investing the profits from these in new houses and more fowls, he might soon work up to a business of respectable dimensions. And this would certainly be a very judicious course, as experience would be acquired just as it was needed. But by the time the poultry yard is yielding a fair living, the owner will find that he has invested in it a sum not far from the amount named, and I am very much mistaken if he would take that amount for his establishment.

Another error commonly made is in getting the wrong kind of land, and too little of it. Although I managed to succeed tolerably well with 1,000 laying hens on about nine available acres, yet I am satisfied that less than an acre and a half to each bundred fowls is not good economy. On less than an acre it is difficult to carry out that projer rotation of crops that is alssolutely necessary, and the fowls, from want of range, do not acquire that vigorous health which I found so desirable. Less than fifteen acres for one thousand birds is not desirable. Attempts have been made to keep poultry in comparatively small coops, but it has never p.icl, except in the case of fancy birls, where time and labor were no olject.

'The land should be all capable of cultivation, and should be as productive as it is possible to get it. Heavy clay and light sand are to be equally avoided ; the former because the birds rarely keep in good health on such soil, and the latter because it is so unproductive. A good deep gravelly loam is the kind to select. Such land does not remain wet long after a rain, and it retains manure and gives good crops. If we allow fifteen acres of such land to each $\mathrm{I}, 000$ fowls, we can raise on it a very large proportion of all the food that is needed. It is supposed that five acres are occupied by coops and yards, and ten acres in cultivation-growing clover, corn, cabbage, etc. Under our system of high cultivation and abundant manure the corn ought to yield at least 40 bushels to the acre, or 400 bushels if the whole were devoted to this crop. This would be about half the corn reyuired. But since clover and cabr bage give larger yields than corn, and as a portion of the ground 
will be in these crops, the proportionate amount of food raised would be increased.

It is often difficult to find land at a moderate price near the market, and it will require good judgment to strike the happy mean between land that is very cheap because it is a long way from market, and land that is so near market that it is very valuable. In the latter case the temptation to confine the fowls to small yards is very strong, and is sure to result in evil. Land suitable for poultry raising ought to be had for \$roo per acre. A higher price than this will load down the enterprise too heavily with interest on capital. At this figure it should be all under cultivation, and should not be in any sense run down. Some have recommended wild land for poultry keeping. By this is meant land that is covered with brush or rocks, and is so poor that it will not pay to cultivate it. Such land may be obtained very cheaply in some parts, but would make a very imprudent investment. We nust bear in mind that the manure from 1,000 fowls is worth a good deal per annum, and on such poor land it is all lost, whereas if the land be good the increase in the crops due to this manure will soon pay for the entire investment.

At the same time, if there should be a piece of -such. wild land laying close to the yards, and for sale at a low figure, it would not be a bad investment, as it would form a grand range for the birds. It would not yield much, but then the young birds would scratch in it and find plenty of insects-just the thing they want. The best use to make of such land, would probably be to plant it in timber. The fowls would keep down the insects. Whether some kinds of vines or fruit trees, might not be grown on it with profit, would be a question worth considering.

In previous pages, we have stated that money made from the sale of pure-bred fowls, must not enter into our calculations. There can be no objection, however, to the poultry keeper turning an honest penny in this way. If he would keep his own stock' up, he must rear pure bred birds, and as he will always have more than he will care to keep, it would be foolish in him not to' get the best prices possible for them. And, if he will confine himself to two or at the most three pure varieties, and take great pains 
with his stock, he may soon acquire a reputation for these breeçls that will bring a handsome sum annually into his pocket. But he must bear in mind that the breeding and selling of fancy fowls, as they are called, is a somewhat speculative business. Pashion seems to have more to do with this matter than has real merit, and the bird which would have brought a large sum yesterday, and which has cost much to rear, may be unsaleable to-day.

In closing these pages, allow me to say that they have been written as much with a view to warn people of the difficulties ahead, as to encourage them to go into poultry keeping. The tendency to adopt some one of the various minor rural pursuits as a business is decidedly on the increase, but we see everywhere, that, where one succeeds, ten fail. 'That this is due to the character of those who go into it, and not to the nature of the business itself, is easily seen from the mere fact, that one succeeds, but we hold that one of the greatest wrongs and injuries that can be inflicted upon the struggling classes, is to present a dazzling picture of success, claiming that any one may attain it. And yet we see daily paraded in various jounnals, the promise that if a person will only get a few good hens, and take care of them, he may soon build up a business that will lead to fortune. And these promises are backed by such an array of figures and statistics, that there seems to be no possibility of disputing them. The eager but inexperienced novice is, therefore, led to invest his time and money in a business of which he knows nothing, and in which he finds out, when it is too late, that failure is the rule and success the exception.

Of one thing $I$ am satisfied: Experience on a small scale, with a few dozen hens, although uncloubtedly valuable, will not enable any one to undertake poultry-keeping on a large scale at once. The difficulties as well as the opportunities which arise when a large number of fowls are kept, are entirely different from those which present themselves on the small scale. But those who will bring an ordinary degree of intelligence to the work, and who have the qualificatious we have already named, may soon acquire

- the necessary experience and skill, and they will find that where there is capital, industry and common sense in the poultry yard, there is money in poultry-keeping. 


\section{Useful Instructive Books}

AT 25 CENTS EACH

The books in the following list are practical and reliable, being especially prepared for self-instruction.

The books are $12 \mathrm{mo}$ in size, printed on good paper, and well illustrated wherever the subject needs it. Bound in neat paper covers. The cheapest series of really good technical books now in print.

Books on other subjects in preparation.

Any book sent postpaid on receipt of $25 \mathrm{c}$., or five for one dollar.

\section{Industrial Publication Company}

\section{Thomas Street;}

NEW YORK

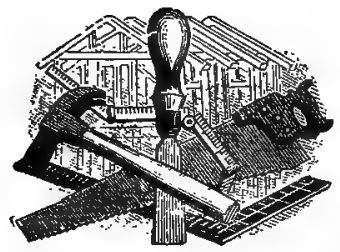

Practical Joinery.-Edited by JoHN BLACK. 92 pages; illustrated by 130 engravings.

A book that points out the best methods in the various departments of joiner's work, such as mould-

ings, classic and Gothic; tongue and groove joints, dowel joints, miter joints, lap joints. dove-tail joints, mortice and teuon joints; cutting timbers, making doors, paneling; hanging doors and windows; skylights; laying down floors; hardwood floors; construction nf niches, etc. Wond working mauhinery; picture frame making, and instructions on how to use the diagonal scale.

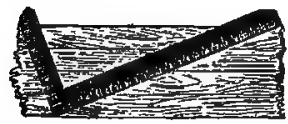

The Steel Square.-By F. T. Hodgson. 48 pages; illustrated by 38 engravings.

This work is intended as an elementary introduction for the use of those who have not time to study the larger works on the same subject. The book shows how some difficult problems in carpentry and joiner'y are simplified and solved by the aid of the carpenter's steel square. together with a full description of the tnol, and explanations of the scales, lines and figures on the blade and tongue, and how to use them in everyday work. Showing how the Square may be user in obtaining the lengths and bevels of rafters, hins, groins, braces, brackets, purlins, collar heams and jack-rafters. Also its application in obtaining the bevels and cuts for hoppers, spring mouldings, octagons, diminished styles, etc. 


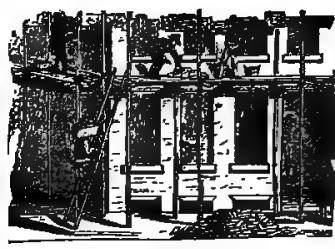

Scaffolding.-Edited by JoHN BLAck. 90 pages; illustrated by 45 engravings.

The subject of the erection of proper seaffolding for various purposes is practically treated in this book. A short history of ancient scaffolding is given, together with directions for erecting ordinary bricklayers scaffolds, ladders; shoring and needling for supporting buildings ; cranes, lifts, hoists, traveling cranes, transporters, cable railways; repairing steeples and tall chimneys ; descriptions of various schemes and aids that will give a fund of practical information to every one called upun to erect scaffolding at the least cost in time and money.

\section{Hints and Aids in Building and Esti-} MATING. A hand-book for every one engaged in the erection and repair of buildings. 36 pages.

This useful little book gives hints and prices; tells how to measure: explains biliding terms, together with a number of tables; schedule of architects" charges and form for bullding contract; form for making estimates; cost of doing work; work a man will do; diameter and height of chimneys; weight of various roof coverings; painting.
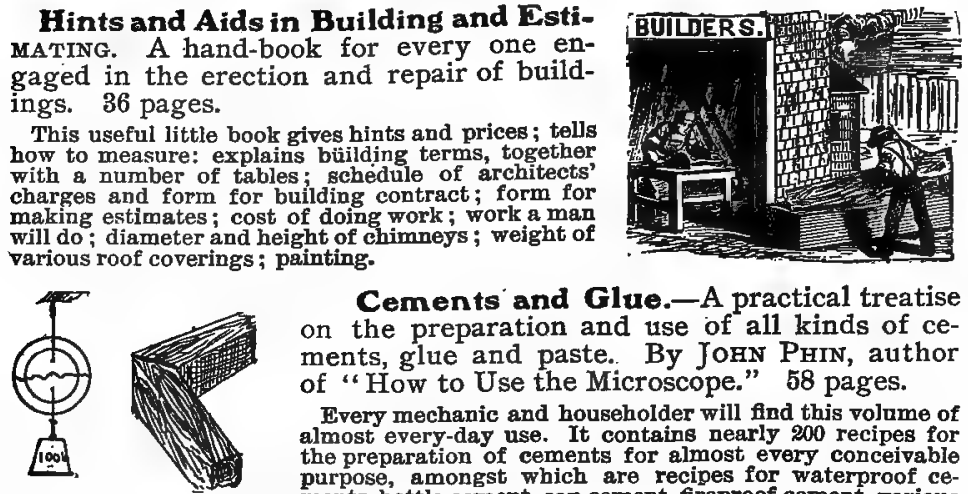

Cements and Glue.-A practical treatise on the preparation and use of all kinds of cements, glue and paste. By JoHN PHIN, author of "How to Use the Microscope." 58 pages.

Every mechanic and householder will find this volume of almost every-day use. It contains nearly 200 recipes for the preparation of cements for almost every conceivable purpose, amongst which are recipes for waterproof cements, bottle cement, cap cement, fireproof cement, various glues, rubber cement, iron cement, ivory cement, leather cement; to cement glass, stone, etc., to metal; different kinds of paste, etc.

Plastering.-Edited by John BLAck. 90 pages; illustrated by 40 engravings.

This book coutains quite a fund of information of a plain and practical character. A short history of the craft is given and then, in order, the materials and methods are described. The art of plastering is described, also the tools used, etc. Other chapters treat of various cements and their uses; lime and cement mortars ; methods of outside and inside work; decorative plastering and details ; stuceo coloring and plaster painting; fixing tiles, mouldings, scagliola, fibrous plaster and other plasters; malsing a scagliola column; making mouldings in fibrous plaster; use of asbestos in the making of fireproof plaster, etc.

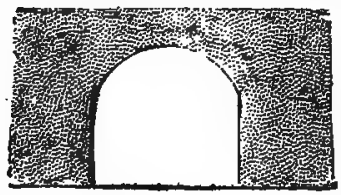

Concrete.-By Frank Jay. 94 pages; illustrated by 38 engravings.

The extensive use of concrete at the present time makes this little manual "fill a long felt want." It is written by an expert of many years' experience in concrete work. The various methods now in vogue are described. The following is a synopsis of the contents: Historical; materials ; aggrugates and proportions: building in concrete; apparatus for erecting buildings : floors, joists and $\mathrm{wallings;}$ concrete paving and flooring; methods of construction; comparisons of different systems: fire resisting qualities; pavings in situ; moulds for concrete work ; making artificial stone; coloring and hardening; armored concrete; manufacture and use of concrete for dams, breakwaters, etc.; use of concrete in building walls, piers, col: umns, floors. chimneys; building armored concrete beams, etc., etc. 
Bricklaying.-Edited by JoHn BLACK. 88 pages; illustrated by 100 engravings.

This book is not intended as a text-book but as a guide to the best practice. The instruction is given in simple, clear langunge, and the following points are treeted: Classes and kjuds of bricks; bouding for sundations and walls; vilasters; piers; window openings; arches, their setting out and construction; bridges, their development and construction; flues, freplaces and chimneys; oriels and bry windows; stops; quoins, coinices, gables: ornamental brickwork; fixing tiles ; general memoranda, etc.

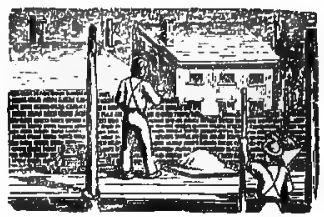

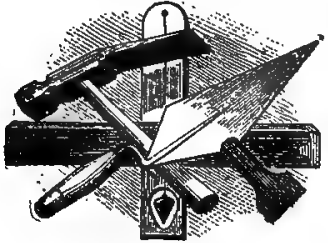

Plumbing and Tinsmiths' Work.Edited by JOHN BLACE. 92 pages; illustrated by 80 engrayings.

This little book deals with roof-covering; roof work; gutters: covering flats, platforms, dormers, ridges, etc.; fnials; pipes; the storago and supply of water; delivery and control of water; elementary sanitation; soil pipes, closets, baths, traps; lead lining for sinks; development of surfaces so as to get the cuts for elbows, angles, etc. ; how flashings should be put down; snow boards: principles of water supply; drinking water supply ; float tanks; hydraulies, etc.

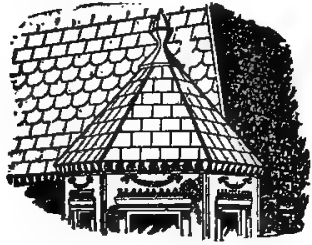

Slating and Tiling.-Ë̈ited by JorN BLACK. 93 pages; illustrated by 50 engravings.

Many buildings now have slate or tile roofs, and this book gives concise information about the various points, such as a history of many roof coverings from the earliest times, also of modern roof coverings, tiles, slates and slating; tools used by roofers; preparation of the roof; different kinds of roofs; description of various forms of framing; more about tiling ; how to lay slates; copper and lead roofs; soldering irons, etc.; zine roofs and concrete roofs ; the use of expand. ed metal, etc.; comparison of different roofing mater-

ials; thatched roofs ; measuring up slating, tiles and other roof covering, with remarks on different methods of measuring.

Decorating.-Edited by JNo. BLAck. 95 pages; illustrated by 15 engravingss.

The subjects treated in this practical book are as follow: Theory of colors; color blindness; the decoration of churches, libraries, dining, sitting and bedrooms; history and application of glass painting; stained glass in decoration; scene painting; carving in wood and stone; stencils; metal work iu decoration. tile decoration, frescoes, plasters; sanitary decoration of the house,
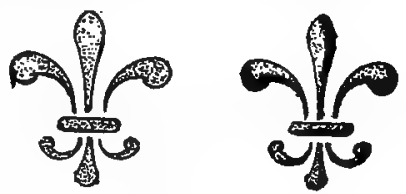

ete. The hints contained in this book will be appreciated by the practical painter and decorator, as well as every householder who desires to have his home neatly and tastefully ornamented. 


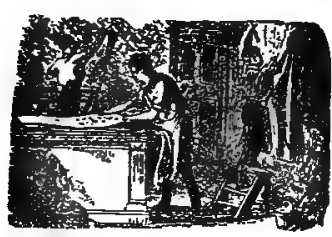

Home Handicrafts,-A Practical Guide for Amateurs. 92 pages; illustrated by 60 engravings.

This book will be appreciated by every one who takes advantage of their spare hours to construct or decorate some detail of their homes. The following synopsis of the contents will show the wide range of snbjects: Tools, materials, planing, workbench, mortise and tenon joint, halved joint, half lap joint, simple doors, out buildings, kitchen table, saw horses, picture frame making ; gluing, Jathing, whitewashing, paperhanging, painting, window boxes, soldering, table fountain. renewing sash lines, rustic railings, meat safes, bicycle racks, green-house work, constructing sun-disls, making a drawing-board, French polishing, kennels, dovecots, poultry houses, useful recipes, etc:

The Slide Rule and How to Use It. 30 pages. By F. T. Hodgson.

This is a compilation of explanations, rules and instructions suitable for mechanics and others interested in the industrial arts. Rules are given for the measure. ment of all kinds of boards and planks, timber in the round or square, glaziers' work and painting, brickwork, paviors' work, tiling and slating, the measurement of vessels of various shapes, the wedge, inclined planes, wheels and axles, levers, the weighing and measuring of metals and all solid bodies, cylinders, cones, globes, octagon rule and formulæ, the measurement of circles, a comparison of French and Bnglish measures, together with much information useful to carpenters, bricklayers, glaziers, paviors, machinists and other mechanics.

The Engineer's Slide Rule and Its Applications.-By WLL- , IAM TONKES. 35 pages.

A complete in vestigation of the pripciples upon which the slide rule is constructed, together with its application to all the purposes of the practical mechanic, such as multiplication, division, extracting roots, powers of numbers, measurement of various plane and solid figures, estimating the weight of various materials, geometrical probems, proportion, change of gears for screw-cutting, calculations on levers, etc. PosGessed of either of the above books and a good slide rule, mechanics might carry in their pockets some hundreds of times the power of calculation that they now have in their heads, and the use of the ingtrument is very easily acquired.

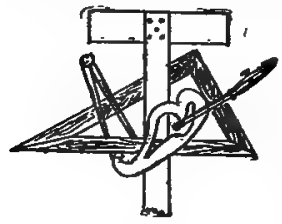

Drawing Instruments. - By AN OLD Draftsman. 48 pages; illustrated by 20 engravings.

A treatise on drawing instruments, with rules for their use and care ; dividers, compasses, ruling pens, bow instruments; specjal forms of instruments: how to handle them; drawing boards, paper, tee-squares, triangles, curves, scales, thumb-tacks, tracing paper and cloth, inks, pencils, protractors; useful memoranda and data for every owner of drawing instruments.

\section{Painting and Varnishing-Edited by} JoHN BLACK. 94 pages; illustrated by 20 engravings.

A practical manual treating on materials, principles of color, mixing paints, preparation of surfaces, distemper, decoration, hints on dealing with customers, hints on the use of brushes, what colors to use in different rooms, etc.; varnishes and varnishing; recipes for making various kinds of varnish; graining, grain. ing to imitate oak, mahogany, satin wood, walnut and

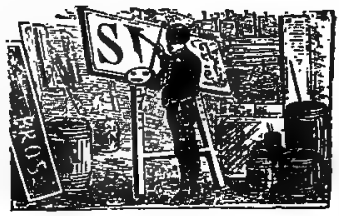
rosew ood ; marbling, white veined, dove colored, red, green, jasper, black and gold, Florentine, Sienna, etc.; inside painting and decoration yilding, sign writing, lettering, al phabets, stencils, monograms, etc; outside painting
brickwork, metal work, etc. 
Hints for Painters, Decorators and Papkr Hangers. - Prepared with Special Reference to the Wants of Amateurs. By An Old Hand. 60 pages.

$A$ most useful book treating on the preparation of surfaces, materials used as bases and vehicles, white lead, linseed and other oils, drlers, coloring paints, mixed pajuts, operations, taste in color, general remarks on graining, miscellaneous receipts, paperhanging, cleaning paper-hangings, varnishing paper, making paste; useful hints, tables, etc., for estimating cost of work and materials which will prove of great value to the beginner in the painting business.

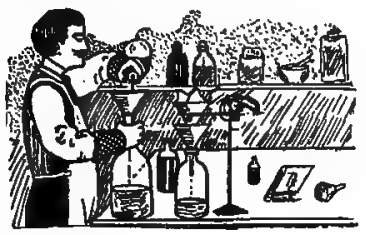

Success with Recipes.-A practical guide to success in the use of recipes, formulæ, etc., with hints on chemical and mechanical manipulation. Intended as a supplement to all books of recipes. By John Phin: 44 pages.

While it is an undoubted fact that many of the recipes published in the ordinary collections are elroweous, either from original blunders on the part of the authors, or from mietakes in copy. ing, failure in the use of others frequently arises from defective information and vicious methods on the part of those who attempt to put them into practicer The object of the present book is to give such hints and cautions as will enable the worker to secure success where success is possible, and where the products are intended for sale it gives valuable advice as to the best methods of puttipg them on the market.

Useful and Precious Miuerals,-How to find them; how to test them and how to estimate their value by simple methods and easily obtained appliances. Intended for the use of nonexperts. Edited by JoHN PHIN. 7\% pages; illustrated by 4 engravings.

This book was prepared to meet the wants of the nonexpert so that they may, by simple tests, know if their "find" is valuable or only useless dirt. To this end the book gives general hints on the examination and testing of minerals; distinguishing characteristics of minerals; a simple method of finding specifle gravity scale of hardness, malleability, color, Juster, crystallization, chemical compositilon; prospecting or searching for minerals, etc.
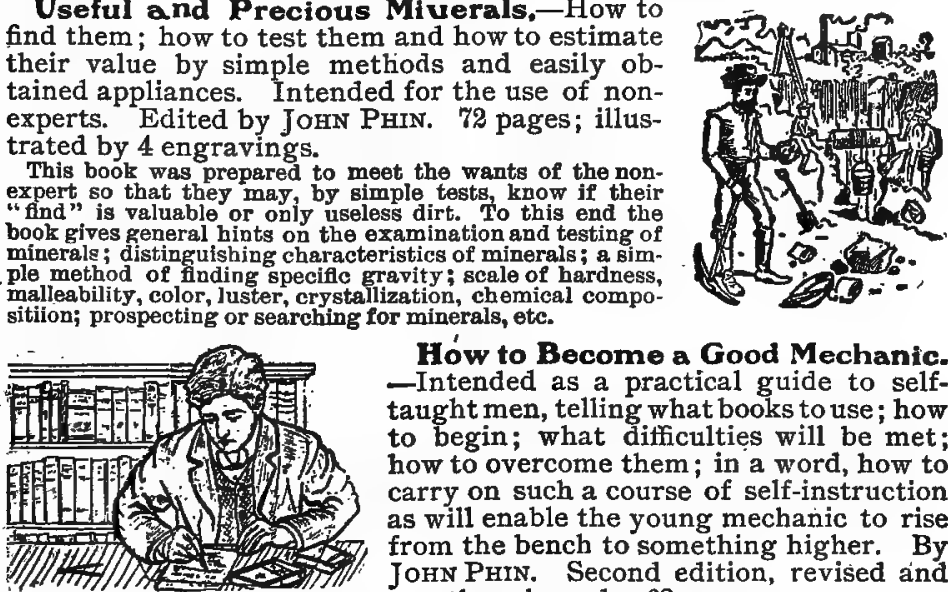

Hów to Become a Good Mechanic. -Intended as a practical guide to selftaught men, telling what books to use; how to begin; what difficulties will be met; how to overcome them; in a word, how to carry on such a course of self-instruction as will enable the young mechanic to rise from the bench to something higher. By JoHn Phin. Second edition, revised and greatly enlarged. 68 pages.

This book is not a text-book, but rather a guide to the use of these books. The anthor briefly outlines a course of study for mechanics who wish to advance them. selves. The notes and instructions given are of a kind that appeal directly to the good sense and reason of the young student, and cannot fail to act as a stimulant to greater efforts in obtaining the knowledge sought. The difficulties which may be expected by the student are dwelt upon, and valuable suggestions as to the proper method of overcoming them are given. 


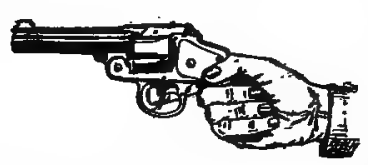

The Pistol as a Weapon of DeFENCE, in the House or on the Road. 50 pages.

This work aims to instruct peaceable and lawabiding citizens in the best means of protecting themselves from the attacks of the brutal and the lawless, and it is the only practical book published on this subject. Its contents are as follows: The pistol as a weapon of defence; the carrying of frearms; different kinds of pistols in market; how to choose a pistol amunition, difierent kinds; powder, caps, bullets, copper cartrjdges, etc.; best form of bullet; how to load ; best charge for pistols; how to regulate the charge ; care of pistol; how to clean it; how to handle and carry it: how to learn to shoot; practical use of the pistol; how to protect yourself and disable your antagonist.

Shooting on the Wing.-Plain directions for acquiring the art of shooting on the wing. With useful hints concerning all that relates to guns and shooting, particularly in regard to the art of loading so as to kill. To which has been added several valuable and hitherto secret recipes of very great practical importance to the sportsman. By AN OLd GamekeEPer. 88 pages; illustrated.

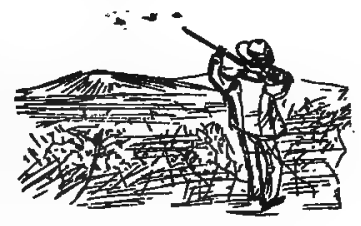

.

This book tells how to choose the gun, about ammunition, gun cases, how to load the gun, how to clean it, how to handle and how to carry it, how to learn to shoot, finishing touches, useful hints; recipes and miscellaneous matter. The book contains a novel and most valuable feature found in no other work on this subject. This is a serles of graduated lessons by which the self-taught roung sportsman is enabled to advance step by step from such easy marks as a sheet of paper nailed on a fence to the most difficult trap-shooting and the sharpest snap-shots.

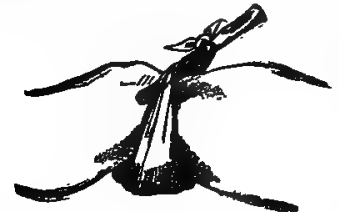

What to Do in Case of Accident.A book for everybody. 96 pages.

This is one of the most useful books ever published. It tells exactly what to do in case of accidents, such as severe cuts, sprains, dislocations, broken bones, burns with fire, acalds, burns with corrosive chemicals, sunstroke, suffocation with foul air, hanging, drowning, frost-bite, fainting, stings, bites, starvation, lightning, poisons, accidents from machinery, gun-shot wounds, etc. etc. It ought to be in every house and workshop, for young and old are liable to accident, and the directions given in this book might be the means of saving many a valuable life.

The Sun.-A familiar description of his phenomena. By Rev. Thomas WiLlIAM WeBB. Author of "Celestial Objects for Common Telescopes." 80 pages; illustrated by 17 engravings.

A book for every one interested in Nature, as it simply and fully describes the sun, tells about spots, eclipses, etc. in a very attractive style, so that the ordinary reader who does not understand astronomy may thoroughly comprehend and enjoy the subject.: A readin
a fair idea of the wonderful universe of which we are a part.

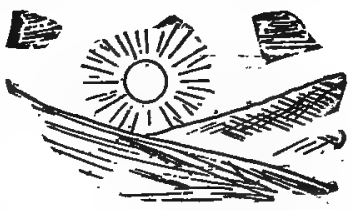

Rhymes of Science: Wise and Otherwise.-By Oliver W. - Holmes, Bret Hart, Ingoldsby, Prof. Forbes, Prof. J. W. Mc.Q. Rankine, Hon. R. W. RAYMond and others. 66 pages ; illustrated.

A collection of scientific rhymes that will form pleasant reading for any one interested in science. 





